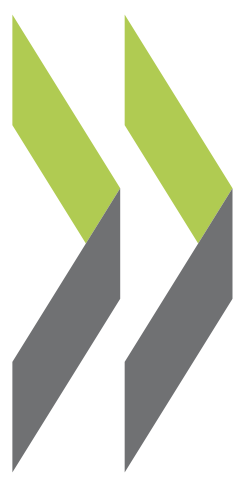

OECD Economics Department Working Papers No. 1210

Skill Mismatch and Public Policy in OECD Countries

\section{Müge Adalet McGowan,}

Dan Andrews 
Organisation de Coopération et de Développement Économiques

Organisation for Economic Co-operation and Development

28-Apr-2015

ECONOMICS DEPARTMENT

English - Or. English

\section{SKILL MISMATCH AND PUBLIC POLICY IN OECD COUNTRIES}

ECONOMICS DEPARTMENT WORKING PAPERS No. 1210

By Müge Adalet McGowan and Dan Andrews

OECD Working Papers should not be reported as representing the official views of the OECD or of its member countries. The opinions expressed and arguments employed are those of the author(s).

Authorised for publication by Jean-Luc Schneider, Deputy Director, Policy Studies Branch, Economics Department.

All Economics Department Working Papers are available at www.oecd.org/eco/workingpapers

JT03375319

Complete document available on OLIS in its original format

This document and any map included herein are without prejudice to the status of or sovereignty over any territory, to the delimitation of international frontiers and boundaries and to the name of any territory, city or area. 
OECD Working Papers should not be reported as representing the official views of the OECD or of its member countries. The opinions expressed and arguments employed are those of the author(s).

Working Papers describe preliminary results or research in progress by the author(s) and are published to stimulate discussion on a broad range of issues on which the OECD works.

Comments on Working Papers are welcomed, and may be sent to the Economics Department, OECD, 2 rue André-Pascal, 75775 Paris Cedex 16, France, or by e-mail to eco.contact@oecd.org.

This document and any map included herein are without prejudice to the status of or sovereignty over any territory, to the delimitation of international frontiers and boundaries and to the name of any territory, city or area.

The statistical data for Israel are supplied by and under the responsibility of the relevant Israeli authorities. The use of such data by the OECD is without prejudice to the status of the Golan Heights, East Jerusalem and Israeli settlements in the West Bank under the terms of international law.

\section{(C) OECD (2015)}

You can copy, download or print OECD content for your own use, and you can include excerpts from OECD publications, databases and multimedia products in your own documents, presentations, blogs, websites and teaching materials, provided that suitable acknowledgment of OECD as source and copyright owner is given. All requests for commercial use and translation rights should be submitted to rights@oecd.org 


\section{ABSTRACT/RÉSUMÉ Skill Mismatch and Public Policy in OECD Countries}

This paper explores the relationship between skill mismatch and public policies using micro data for 22 OECD countries from the recent OECD Survey of Adult Skills (PIAAC). Results suggest that differences in skill mismatch across countries are related to differences in public policies. After controlling for individual and job characteristics, well-designed product and labour markets and bankruptcy laws that do not overly penalise business failure are associated with lower skill mismatch. Given the negative relationship between skill mismatch and labour productivity, reducing skill mismatch emerges as a new channel through which well-designed framework policies can boost labour productivity. Skill mismatch is also lower in countries with housing policies that do not impede residential mobility (e.g. transaction costs on buying property and stringent planning regulations). Greater flexibility in wage negotiations and higher participation in lifelong learning as well higher managerial quality are also associated with a better matching of skills to jobs.

JEL Classification: I20; J20; J24; J61.

Keywords: Human capital, skill mismatch, reallocation, education, allocation of talent, framework policies, labour mobility.

$* * * * * * * * * * * * * * * * * * * *$

\section{Inadéquation des compétences et action des pouvoirs publics dans les pays de l'OCDE}

Ce Document de travail analyse la relation entre inadéquation des compétences et politiques publiques, à l'aide de micro-données recueillies pour 22 pays de l'OCDE à partir de la récente enquête PIAAC (Programme de l'OCDE pour l'évaluation internationale des compétences des adultes). Les résultats donnent à penser que les différences d'inadéquation des compétences d'un pays à l'autre sont le fruit de différences dans l'action des pouvoirs publics. Une fois isolé l'effet des caractéristiques des individus et des emplois, on observe qu'une réglementation des marchés de produits et du travail bien conçue et une législation sur la faillite pas trop pénalisante pour les défaillances d'entreprises vont de pair avec un moindre niveau d'inadéquation des compétences. Compte tenu de la corrélation négative entre l'inadéquation des compétences et la productivité de la main-d'œuvre, la lutte contre ce phénomène s'offre comme une nouvelle voie par laquelle des politiques publiques bien pensées peuvent susciter des gains de productivité. De même, l'inadéquation des compétences est moindre dans les pays où la politique du logement n'est pas un frein à la mobilité résidentielle (par les coûts de transaction sur les acquisitions immobilières ou la sévérité des règlements d'urbanisme). Enfin, une plus grande marge de manœuvre dans les négociations salariales, une participation plus forte à l'éducation et la formation tout au long de la vie et une meilleure qualité de la gestion d'entreprise vont également de pair avec une meilleure correspondance entre compétences et emplois.

Classification JEL : I20; J20; J24; J61.

Mots-clés : capital humain, inadéquation des compétences, redéploiement, éducation, distribution des compétences, politiques-cadres, mobilité de la main-d'œuvre. 


\section{TABLE OF CONTENTS}

SKILL MISMATCH AND PUBLIC POLICY IN OECD COUNTRIES......................................................

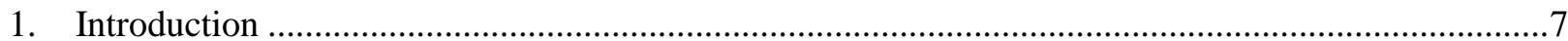

2. Reducing skill mismatch can improve the allocation of skills and productivity ..............................9

$2.1 \quad$ Cross-country differences in skill mismatch are significant......................................................

2.2 Skill mismatch and cross-country gaps in labour productivity ...............................................11

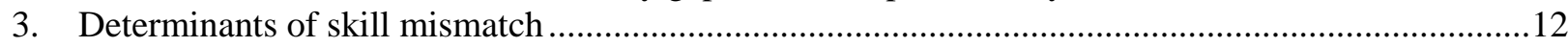

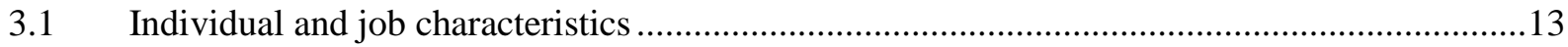

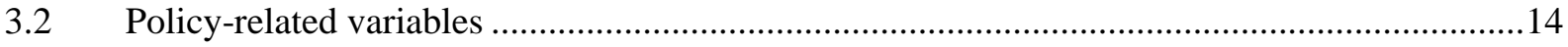

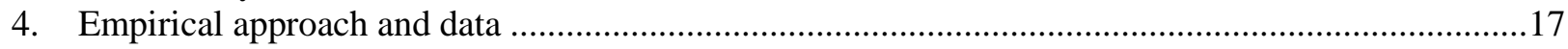

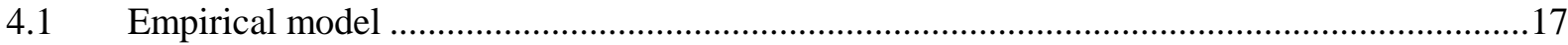

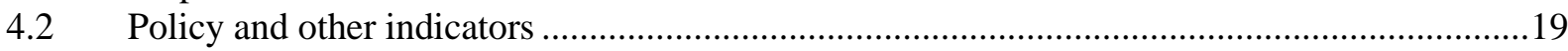

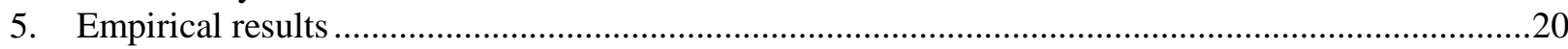

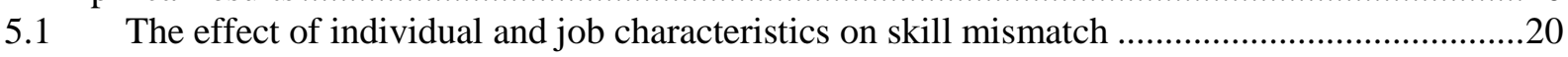

5.2 The effect and economic significance of policy-related factors on skill mismatch...................22

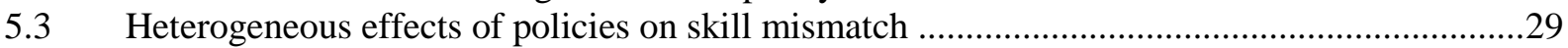

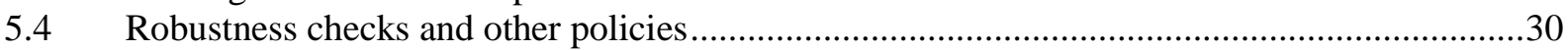

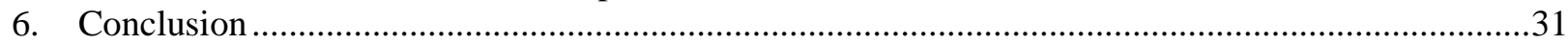

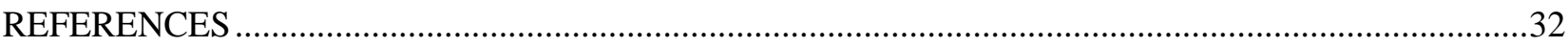

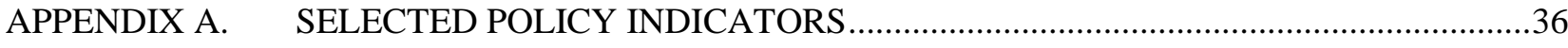

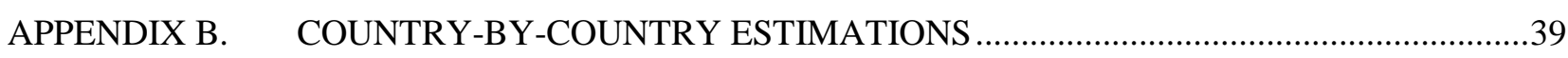

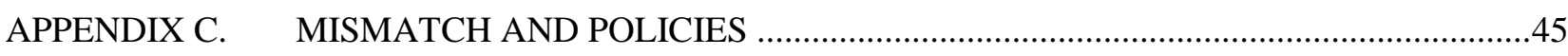

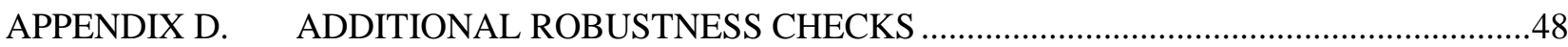

\section{Tables}

Table 1. The effect of individual characteristics on skill mismatch: pooled cross-country regressions .21

Table 2. The effect of policy-related factors on skill mismatch.......................................................24

Table 3. Estimated gains to labour productivity from policy reforms that reduce skill mismatch ..........26

Table 4. Heterogeneous effects of policies on skill mismatch .........................................................30

Table A1. Data sources for policy-related variables.............................................................................

Table B1. Individual characteristics and skill mismatch: country-by-country regressions ......................39

Table B2. Individual characteristics and over-skilling: country-by-country regressions .........................41

Table B3. Individual characteristics and under-skilling: country-by-country regressions .......................43

Table $\mathrm{C} 1$. The effect of policy-related factors on over-skilling ...............................................................45

Table C2. The effect of policy-related factors on under-skilling............................................................46

Table D1. Correlations between selected policy-related variables .......................................................48

Table D2. Including several policies together: robustness checks.........................................................49 


\section{Figures}

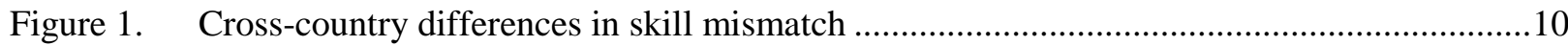

Figure 2. Counterfactual productivity gains from reducing skill mismatch ......................................12

Figure 3. Residential mobility and worker reallocation rates ...........................................................16

Figure 4. The probability of skill mismatch and framework policies ................................................25

Figure 5. The probability of skill mismatch and other policies ....................................................27

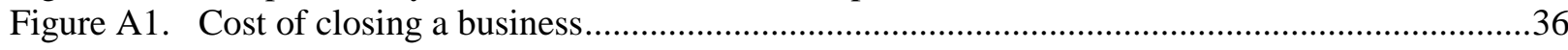

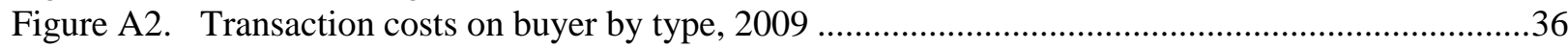

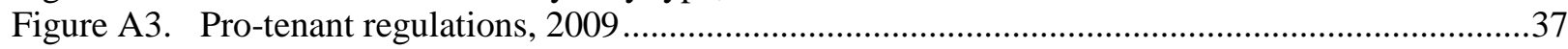

Figure A4. Number of days to obtain a building permit, 2014 ..........................................................38

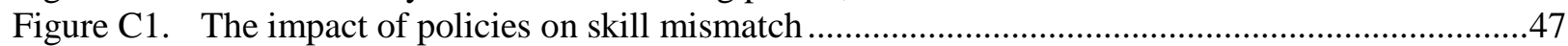

\section{Boxes}

Box 1. Measuring skill mismatch from the OECD Survey of Adult Skills (PIAAC) 
ECO/WKP(2015)28 
ECO/WKP(2015)28

\title{
SKILL MISMATCH AND PUBLIC POLICY IN OECD COUNTRIES
}

\author{
By Müge Adalet McGowan and Dan Andrews ${ }^{1}$
}

\section{Introduction}

1. This paper analyses the relationship between policies and the incidence of skill mismatch in 22 OECD countries. Recent OECD work has shown that skill mismatch has the potential to explain a nontrivial share of cross-country labour productivity gaps (Adalet McGowan and Andrews, 2015). Furthermore, skill mismatch matters for the future of productivity as the rate of increase in the stock of human capital is projected to slow (Braconier et al., 2014), raising the importance of the ability of economies to efficiently deploy their existing stock of human capital. However, skill mismatch indicators derived from the OECD Survey of Adult Skills, a product of the Programme for the International Assessment of Adult Competencies (PIAAC), show that on average across countries, around one quarter of workers report a mismatch between their existing skills and those required for their job, implying that there is considerable scope to improve the efficiency of human capital allocation in OECD countries. This issue takes on heightened importance in light of evidence that mismatch has increased over time (European Commission, 2013).

2. According to the theoretical and empirical literature, mismatch will be shaped by two key factors: i) individual and workplace/job characteristics; and $i i$ ) a policy environment that can reduce distortions to labour mobility. Together with the usual individual and job characteristics (e.g. age, gender, firm size), recent OECD evidence that under-skilling is related to labour productivity through the within-firm productivity channel motivates the consideration of policies that work through this factor (Adalet McGowan and Andrews, 2015). For example, better managerial quality, which can be facilitated by procompetitive product market regulations, is associated with lower skill mismatch.

3. At the same time, there is a strong negative relationship between skill mismatch (over-skilling) and labour productivity via the allocative efficiency channel. One explanation for this could be that as firms draw from a scarce and fixed pool of skilled labour, trapping resources in relatively low productivity firms - which tends to occur in industries with a high share of over-skilled workers - can make it more difficult for more productive firms to attract skilled labour and gain market shares at the expense of less productive firms (Adalet McGowan and Andrews, 2015). Given the link between mismatch and allocative efficiency, and existing evidence that framework policies affect reallocation (Andrews and Cingano, 2014), the working hypothesis in this paper is that cross-country differences in skill mismatch may partly reflect

1 Corresponding authors are: Müge Adalet McGowan (muge.adaletmcgowan@oecd.org) and Dan Andrews (dan.andrews@oecd.org) from the OECD Economics Department. From the Economics Department, they would like to thank Christian Kastrop, Catherine L. Mann, Giuseppe Nicoletti, Alessandro Saia, Jean-Luc Schneider and participants at a departmental Brown Bag Seminar. From the Employment, Labour and Social Affairs Directorate, they would like to thank Glenda Quintini, and from the Education and Skills Directorate, participants at a PIAAC Brown Bag Seminar. Special thanks go to Veronica Borg and Francois Keslar (at the Education Directorate) and Paulina Granados Zambrano (at the Employment, Labour and Social Affairs Directorate) for help with data and Catherine Chapuis and Sarah Michelson for excellent statistical and editorial support. 
regulations affecting product and labour markets and bankruptcy proceedings. ${ }^{2}$ In other words, the paper aims to shed some light on one of the channels through which framework policies, namely skill mismatch, can increase productivity.

4. Accordingly, this paper uses microdata from PIAAC to provide new evidence on the relationship between skill mismatch and policies, controlling for a host of individual and job characteristics, in OECD countries. Causation is difficult to establish given data limitations: $i$ ) the data is available only at one point in time; and ii) due to high correlations between the policy variables, the baseline analysis includes the policy variables one at a time (although the results are broadly robust to including several less interrelated policy variables together). Nevertheless, a number of robust correlations between policy variables and skill mismatch emerge.

5. Results suggest that differences in skill mismatch across countries are associated with differences in the policy environment. After controlling for individual and job characteristics, skill mismatch is lower in countries with well-designed framework conditions that promote efficient reallocation, while housing policies that do not impede residential mobility also loom large. Lower mismatch is also associated with greater flexibility in wage negotiations and higher participation in lifelong learning as well as higher managerial quality.

6. More specifically, the main findings can be summarised as follows:

- Cross-country estimates show that mismatch is more likely among the young and those with higher levels of educational attainment, suggesting that policies to increase educational levels may not be sufficient to address mismatch.

- A competitive and open business environment that favours the adoption of superior managerial practices is associated with lower skill mismatch.

- The positive effects of high managerial quality for reducing mismatch could be lowered by stringent employment protection legislation (EPL) that imposes heavy or unpredictable costs on hiring and firing, slowing down the reallocation process.

- Framework policies that affect firm entry and exit and the efficiency of matching in labour markets are particularly important. For example, less cumbersome product market regulations (PMR) and EPL and bankruptcy legislation that does not excessively punish business failure are associated with lower skill mismatch. The role of bankruptcy law is particularly strong: reducing the cost of closing a business from its most restrictive level in Italy to the median level in Canada is associated with a 10 percentage point decrease in the probability of mismatch.

- Less stringent EPL is also associated with lower mismatch amongst youth, since it provides scope to improve the quality of job-worker matching, which is naturally lower amongst young people due to their lack of experience.

- Policies that promote residential mobility- e.g. lower transaction costs on buying property and less stringent planning regulations and rental contracts - are associated with lower skill mismatch. The estimated impact of transaction costs is particularly strong: reducing transaction costs from the highest level (Belgium) to the median level (Finland) is associated with a reduction in the probability of mismatch of around 7 percentage points.

2 Despite the widespread evidence that over-skilling is the more prevalent type of mismatch, policy debates tend to focus on skill shortages and gaps (e.g. raising the educational profile of the labour force), without emphasis on other types of policies that may improve the allocation of skills. 
- High transaction costs and strict rental market regulations are associated with disproportionately higher mismatch amongst youth, who might be naturally more susceptible to mismatch if they have fewer resources to finance the higher moving costs that these policies imply.

- A higher degree of flexibility to at least allow scope for wage bargaining around some centrallyagreed standards to take place at the firm level, proxied by a lower coverage rate of collective bargaining agreements ${ }^{3}$, is also associated with lower mismatch.

- Higher participation in lifelong learning is associated with lower mismatch, as training beyond formal education can address changing labour market needs (e.g. due to technological advances). Increasing participation in lifelong learning from the lowest level (Italy) to the median (Estonia) is associated with a 6 percentage point reduction in mismatch.

7. Given the negative relationship between skill mismatch and labour productivity, these results provide new evidence on a possible channel through which well-designed framework policies may boost productivity. For example, reducing the cost of closing a business from its most restrictive level to the median level is associated with a 3.6 percentage point implied gain to labour productivity, while a similar reduction in transaction costs on buying property implies a 2.5 percentage point gain to labour productivity. However, these estimates should be treated with caution as they reflect bivariate correlations rather than causal links.

8. The paper proceeds as follows. The next section defines the mismatch indicators and presents some industry-level evidence on the links between mismatch and productivity. Section 3 discusses the channels through which individual and job characteristics and policies can affect mismatch. Section 4 outlines the empirical methodology used to estimate the relationship between mismatch, individual and job characteristics and policies. Section 5 presents the baseline results, robustness tests and the economic significance of the effects of policies on mismatch. Section 6 offers some concluding thoughts.

\section{Reducing skill mismatch can improve the allocation of skills and productivity}

\subsection{Cross-country differences in skill mismatch are significant}

9. Indicators of skill mismatch, constructed from the OECD Survey of Adult Skills (see Box 1 and Adalet McGowan and Andrews, 2015 for more details), suggest that there is considerable scope to improve the efficiency of human capital allocation in OECD economies. For example, on average across countries, roughly one-quarter of workers report a mismatch between their existing skills and those required for their job; i.e. they are either over- or under-skilled. Moreover, important cross-country differences emerge, with the incidence of skill mismatch ranging from around one-third in Italy, Spain and the Czech Republic, to less than one-fifth in a diverse set of countries, including Sweden and the United States (Figure 1, Panel A). Over-skilling is generally more common than under-skilling, with being over-skilled on average roughly two and a half times more widespread than being under-skilled (Figure 1, Panel B). Nevertheless, there are cross-country differences in rates of under-skilling, which is relatively high in Italy, the Slovak Republic and the United Kingdom, for example. 
Figure 1. Cross-country differences in skill mismatch

Panel A: Percentage of workers with skill mismatch; selected OECD countries, 2011-12

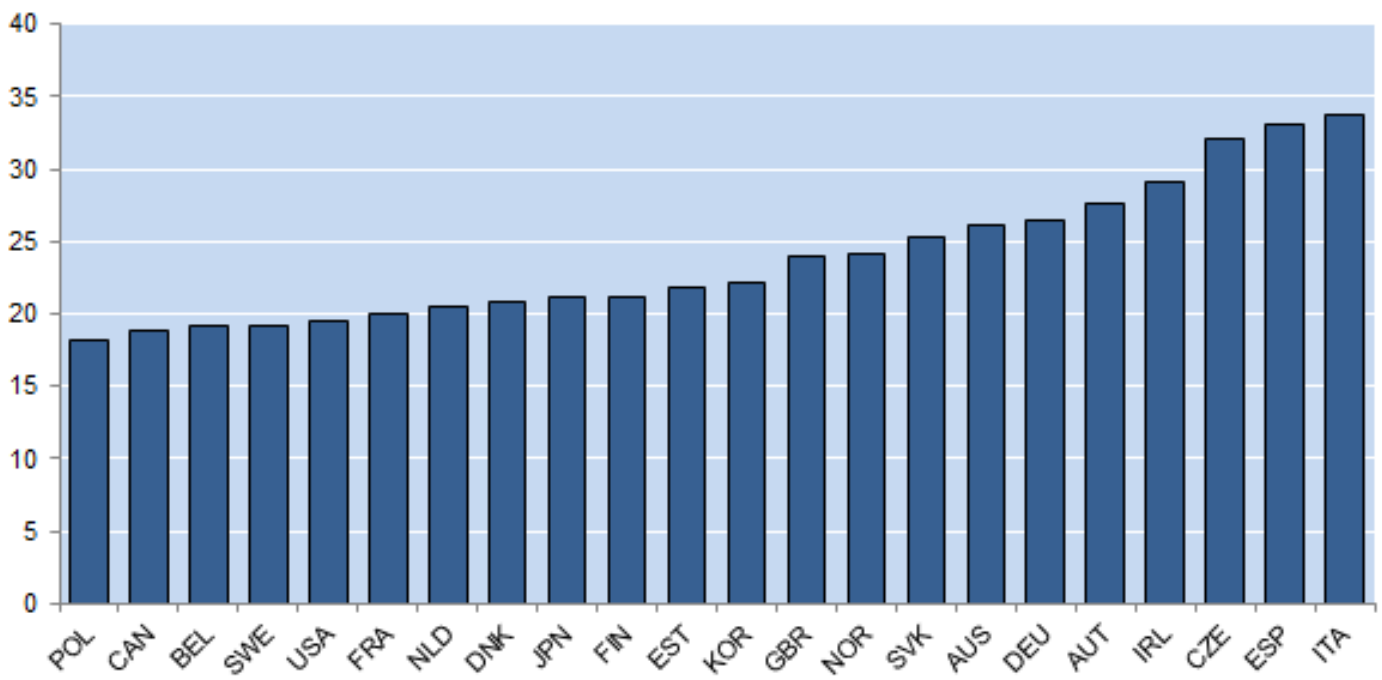

Panel B: Components of skill mismatch; selected OECD countries, 2011-12

ם Over-skilling aUnder-skilling

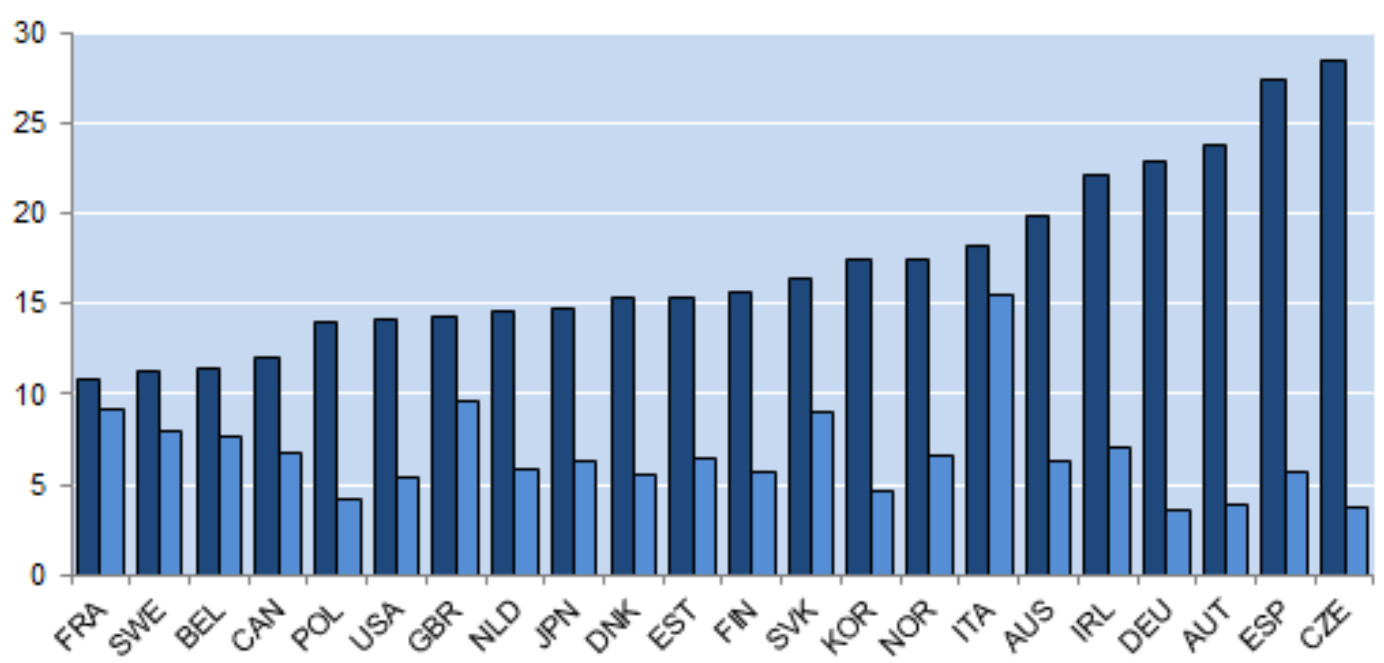

Note: The figure shows the percentage of workers who are either over- or under- skilled (see Box 1 for definitions), for a sample of 11 market industries: manufacturing; electricity, gas, steam and air conditioning supply; water supply; construction; wholesale and retail trade; transportation and storage; accommodation and food service activities; information and communication; real estate activities; professional, scientific and technical activities, and administrative and support service activities. In order to abstract from differences in industrial structures across countries, the 1-digit industry level mismatch indicators are aggregated using a common set of weights based on industry employment shares for the United States.

Source: OECD calculations based on the Survey of Adult Skills (2012). 


\section{Box 1. Measuring skill mismatch from the OECD Survey of Adult Skills (PIAAC)3}

The Survey of Adult Skills assesses the proficiency of adults aged between 16 and 65 in literacy, numeracy and problem solving in technology-rich environments in 22 OECD countries. ${ }^{1}$ Besides the level of skills, information was collected on the background of respondents, their education and labour market experience, their skill use at work and at home plus indicators of well-being. The Survey, conducted in 2011-12, has a number of advantages over comparable datasets as it extends the number of countries, sample size per country and the range of assessed skills.

Skill mismatch can be measured in several ways, each with their advantages and disadvantages. One is through self-assessment by asking workers to compare their skill level and that required for their job. Another approach is to compare the skill levels - as measured by proficiency scores - to skill use at work. A final approach, developed in OECD (2013) and employed in this analysis, combines information on self-reported skill mismatch and quantitative information on skill proficiency by:

1. The (literacy) proficiency scores of workers who report themselves as well-matched - i.e. those who neither feel they have the skills to perform a more demanding job nor feel the need for further training in order to be able to perform their current job satisfactorily - are used to create a quantitative scale of the skills required to perform the job for each occupation (based on 1-digit ISCO codes). ${ }^{2}$

2. Using this scale of proficiency scores of well-matched workers, minimum and maximum threshold values based on the $5^{\text {th }}$ and $95^{\text {th }}$ percentile, for example - are identified, which effectively provide the bounds that define what it is to be a well-matched worker. ${ }^{3}$

3. Respondents whose scores are lower (higher) than this minimum (maximum) threshold in their occupation and country, are classified as under- (over-) skilled. By contrast, respondents whose proficiency scores reside within these bounds are not counted as mismatched, regardless of whether they self-report as being well-matched or mismatched.

1. Australia, Austria, Belgium (Flanders), Canada, the Czech Republic, Denmark, Estonia, Finland, France, Germany, Ireland, Italy, Japan, Korea, the Netherlands, Norway, Poland, the Slovak Republic, Spain, Sweden, the United Kingdom (England and Northern Ireland) and the United States.

2. Literacy is defined as the ability to understand, evaluate, use and engage with written texts to participate in society, to achieve one's goals, and to develop one's knowledge and potential.

3. The analysis here uses different threshold values based on the 10 th and 90th percentiles.

\subsection{Skill mismatch and cross-country gaps in labour productivity}

10. While skill mismatch may be influenced by temporary factors, ${ }^{4}$ the relative persistence in skill mismatch through time and across different socio-economic groups (Mavromaras et al., 2012 and 2013) suggests that these differences may be symptomatic of structural inefficiencies in the allocation of skills. Accordingly, new OECD research uses cross-country data to explore the direct relationship between mismatch and industry-level labour productivity indicators, constructed from firm level data (Adalet McGowan and Andrews, 2015). ${ }^{5}$ Skill mismatch and aggregate productivity could be related through two channels: lower (or higher) within-firm productivity and a less efficient allocation of labour resources across firms. Higher skill mismatch is found to be associated with lower aggregate labour productivity via the channel of less efficient resource allocation. Furthermore, this largely reflects the strong negative correlation between over-skilling and productivity. One explanation for this could be that as firms draw from a scarce and fixed pool of skilled labour, trapping resources in relatively low productivity firms which tends to occur in industries with a high share of over-skilled workers- can make it more difficult for more productive firms to attract skilled labour and gain market shares at the expense of less productive firms. Moreover, these effects of mismatch on resource allocation are sizeable enough to more than offset any private productivity benefit that may accrue to the firms that actually employ these over-skilled workers.

$4 \quad$ For example, imbalances between the demand for and supply of different skills will inevitably arise, due to economic shocks, imperfect information about opportunities in the labour market and improvements in technology and organisational practices (Robst, 1995; Sicherman, 1991).

Cross-country research into this issue is rare and the existing literature typically does not estimate the direct effect of mismatch on productivity, but rather infers it indirectly from wages, job satisfaction and other correlates of productivity (Hartog, 2000). 
11. Figure 2 simulates the potential gain to labour productivity from reducing skill mismatch in each country to the best practice level in each industry. ${ }^{6}$ If interpreted causally, reducing skill mismatch in countries such as Italy and Spain to the best practice level would be associated with an increase in allocative efficiency of around 10\%. This accounts for about around one-fifth of the gap in non-farm business sector allocative efficiency between Italy and the United States (or Sweden). From this perspective, skill mismatch has the potential to explain a non-trivial share of cross-country labour productivity gaps, thus motivating an analysis of the link between policies and mismatch.

Figure 2. Counterfactual productivity gains from reducing skill mismatch

Simulated gains to allocative efficiency from lowering skill mismatch to the best practice; per cent

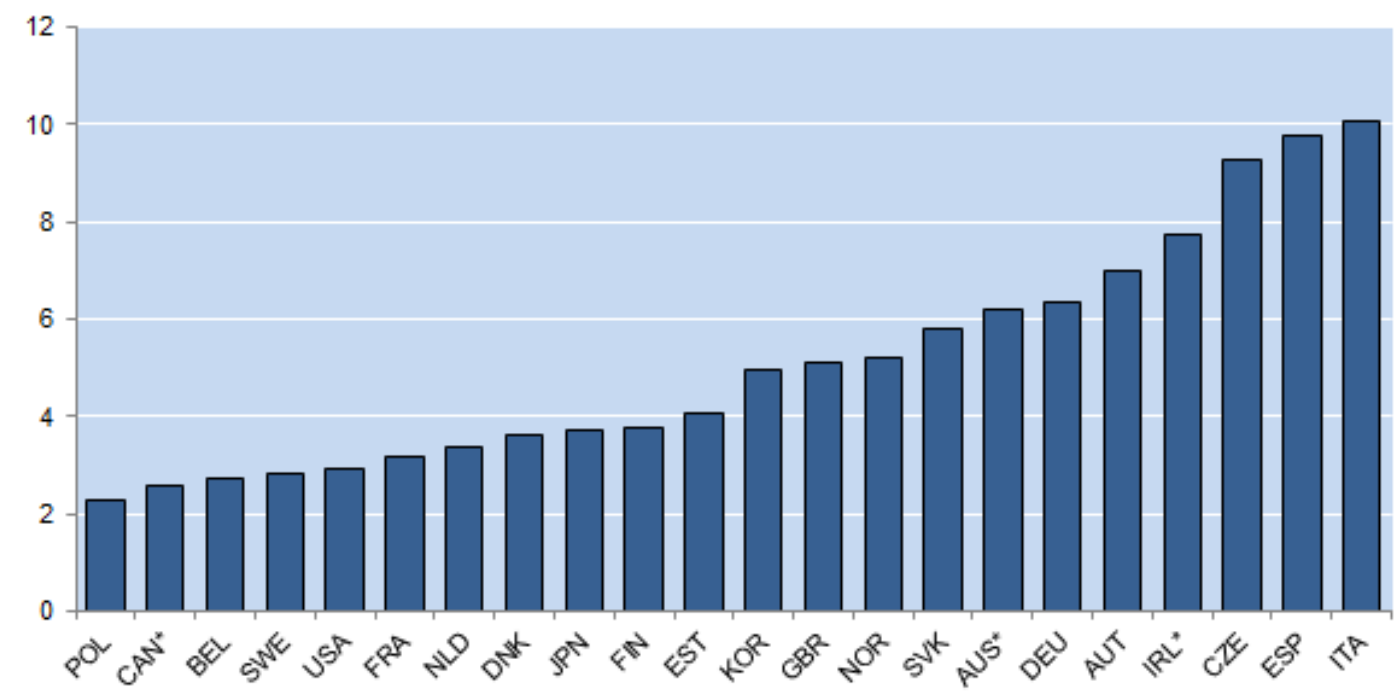

Note: The chart shows the difference between the actual allocative efficiency and a counterfactual allocative efficiency based on lowering the skill mismatch in each country to the best practice level, which implies a productivity gain of around $10 \%$ in Italy and $3 \%$ in the United States. 1-digit industry level mismatch indicators are aggregated using a common set of weights based on the industry employment shares for the United States. The estimated coefficient of impact of mismatch on productivity is based on a sample of 19 countries for which both firm level productivity and mismatch data are available. While mismatch indicators are available for Australia, Canada and Ireland in the Survey of Adult Skills, the estimates gains to allocative efficiency for these three countries should be interpreted with caution to the extent that they are not included in the econometric analysis due to insufficient productivity data.

Source: OECD calculations based on the Survey of Adult Skills (2012).

\section{Determinants of skill mismatch}

12. If interpreted causally, the estimates above suggest that mismatch is one factor that may contribute to explaining cross-country differences in labour productivity. Hence, it is important to consider what factors explain skill mismatch. According to the theoretical and empirical literature, mismatch will be shaped by two key factors: i) individual and workplace/job characteristics; and ii) policy-induced distortions to labour mobility. 
ECO/WKP(2015)28

\subsection{Individual and job characteristics}

13. Theoretical models (namely assignment theory) suggest that there is a relationship between a worker's skill profile and the skill content of their job, concentrating on both individual and job characteristics in determining mismatch. Accordingly, it is important to control for both individual and job characteristics in any analysis of skill mismatch. ${ }^{7}$ Some of these characteristics, such as age, migrant status and firm size, which have been prevalently featured in the literature, are discussed below. It should be noted that the impact of such factors on mismatch tends to vary depending on the definition and type of mismatch (qualification, skills, field of study), the country examined and the time frame. ${ }^{8}$ Furthermore, differences in the propensity to experience skill mismatch could also be exacerbated by the policy environment (See Section 3.2).

\subsubsection{Age}

14. Many OECD economies, especially those with segmented labour markets, have difficulties in successfully integrating young people into the labour market both by getting them out of unemployment and matching them to the right jobs. Over-skilling could be more common amongst the youth since they are more likely to be employed in temporary or entry-level jobs where skill demands could be low. Both country-level and cross-country studies find that young people are significantly more likely to be overskilled than older workers (Allen et al., 2013; OECD, 2013). This could be due to search and information costs, which result in longer times in finding one's niche in the labour market. There is also some evidence that as workers get more experience and relevant information on job market opportunities, their mismatch is reduced (Alba-Ramirez, 1993). Youth over-skilling may also decrease over time as employers learn to use information other than formal qualifications to fill vacancies and share job content based on revealed skills (OECD, 2014a).

15. While the degree of mismatch should improve with experience (Desjardins and Rubenson, 2011), older workers can suffer from skills obsolescence due to technological progress and the ageing process (Quintini, 2011). ${ }^{9}$ However, this does not take account of non-formal education and skill development activities individuals undertake after being hired, highlighting the importance of lifelong learning in reducing mismatch (Section 3.2).

\subsubsection{Migrant status}

16. The literature on the links between skill mismatch and migrant status is scarce and inconclusive. For example, Nieto et al. (2013) do not find any significant difference in the probability of having skill mismatch between natives and immigrants (from EU countries) while migrants from non-EU countries are more likely to be mismatched, once individual characteristics are controlled for. This reflects the importance of controlling for the heterogeneity amongst the migrant population. The region of origin, the native language, length of residence and work experience in the host country, place of acquisition of formal qualifications, age at migration and migrant generation can be important determinants of whether migrants are more likely to be mismatched (Battu and Sloane, 2004; Lindley, 2009; Green, Keler and Leeves, 2007; OECD, 2014b).

7 Human capital theory highlights the importance of individual characteristics in determining mismatch, while job competition and labour market segmentation theories concentrate on job characteristics. Empirical evidence suggests that assignment theory is good at explaining persistence of mismatch (Hartog and Oosterbeck, 1988; McGuinness, 2006). See Quintini (2011) for a detailed discussion.

8 For example, Verhaest and Omey (2009) find that the use of different measures of qualification mismatch yields different results when analysing the determinants of over-qualification in the Netherlands.

9 At the same time, there is some evidence that older workers are generally less involved in new workplace organisational changes, which might lead to higher mismatch (Eurofound, 2008). 
17. Research has focused more on the links between qualification mismatch and migrant status and finds that the incidence of over-qualification is higher for immigrants compared to natives (Aleksynska and Tritah, 2013; Chiswick and Miller, 2009; Kler, 2006). This might reflect the fact that human capital acquired prior to immigration is not fully transferable due to a lack of knowledge of the host country language, discrimination and the inability of employers to judge qualifications or work experience gained abroad efficiently. Some of these factors are more likely to result in qualification mismatch, making migrant status potentially more relevant for qualification rather than skill mismatch. ${ }^{10}$

\subsubsection{Firm size and managerial quality}

18. The evidence on the links between firm size and skill mismatch are ambiguous. Quintini (2011) finds no significant relationship between skill mismatch and firm size, but other cross-country studies find that over-skilling increases with firm size (Allen et al., 2013). One potential reason for this could be that large firms are more complex and matching workers to the right jobs is more difficult. Another is that larger firms, which are likely to be less financially-constrained, can afford to $i$ ) use a recruitment strategy to ensure a continuous and uninterrupted supply of high skills by hoarding over-skilled workers; and ii) invest in the training of already high-skilled workers (Cedefop, 2012). Such management practices might result in over-skilling in larger firms. On the other hand, better human resource policies at large firms can make it possible to transfer their workers to better matches inside the firm, lowering mismatch.

19. The empirical evidence on the links between firm characteristics and managerial ability and skill mismatch are scarce (Oyer and Scahefer, 2011). ${ }^{11}$ Better managed firms may be less susceptible to mismatch by being more effective at: i) screening potential job applicants; ii) developing new work practices to more effectively integrate new technologies; iii) internally reallocating over-skilled/qualified workers to more productive uses within the firm; and $i v$ ) taking remedial measures and/or removing underskilled/qualified workers from the firm. ${ }^{12}$ New OECD evidence shows that better managerial quality can account for the negative relationship between under-skilling and lower within-firm productivity, and that larger firms are more likely to be better managed (Adalet McGowan and Andrews, 2015), suggesting that under-skilling could be less likely in larger firms.

\subsection{Policy-related variables}

20. As discussed above, cross-country differences in skill mismatch can be due to structural differences in supply and demand as well as cyclical factors. The existence of such structural imbalances in the labour market makes it crucial to use several types of policies in order to address frictions that affect the efficiency of labour reallocation, arising from policy-induced frictions (e.g. labour market regulations; see Hopenhayn and Rogerson, 1993) or structural factors that prevent geographical mobility across regions. In the subsequent analysis, only a subset of potentially relevant policies (framework, housing, education and labour market) for which indicators are readily available are covered, but a range of other policies (e.g. vocational education and training and the matching of available university programmes to labour market demand needs) that are more difficult to measure may also matter. Of course, policies to increase human capital accumulation, such as investment in higher education, are also crucial (Braconier et al., 2014).

10 OECD (2014b) shows that while migrants are more likely to be over-qualified in all OECD countries in the study, they are only likely to be over-skilled in some countries and the gap with natives is much smaller for over-skilling compared to over-qualification. First generation immigrants are also on average more likely to be over-qualified but well-matched in terms of skills than natives (Prokic-Breuer and McManus, 2013).

11 Measuring the impact of human resources on mismatch is difficult as the effectiveness of one practice can depend on its complementarity with others (Bloom and van Reneen, 2011).

12 Better management of skills can be achieved through better hiring practices, job design and training options at the firm level (Cedefop, 2012; Weststar, 2009; World Economic Forum, 2014; Cappelli, 2014). 


\subsubsection{Framework policies}

21. There is a vast literature on the importance of framework policies for productivity and resource allocation. The strong negative relationship between skill mismatch (i.e. over-skilling) and labour productivity via the allocative efficiency channel (Adalet McGowan and Andrews, 2015) suggests that policy determinants of skill mismatch should focus particularly on those policy factors that impose frictions to the efficient reallocation of labour. Previous research has highlighted the effects of flexible product and labour market regulations and bankruptcy legislation that does not excessively penalise business failure on the efficiency of resource allocation (Andrews and Cingano, 2014). Given this, skill mismatch might be one channel through which such framework policies affect labour productivity.

22. Stringent regulations on the firing of permanent employees make it more difficult for firms to adapt the labour force structure to address mismatch between the demand and supply of skills (Di Pietro, 2002). Using the 1994-2001 waves of European Community Household Panel Surveys, Brunello et al. (2007) find that employment protection legislation (EPL) might increase mismatch by making it harder for workers to get their first job and more difficult to fire because of firing restrictions. The use of fixed-term contracts and temporary work contracts may help avoid strict firing rules, and thus reduce mismatch.

23. Policies that decrease barriers to firm entry and increase general competition (e.g. procompetitive product market regulations) might improve the allocation of skills through several channels. First, by preventing the creation of rents and improving market selection (Pica and Rodriguez, 2005) such policies will allow high skilled workers to be employed in high productivity firms. ${ }^{13}$ Second, they can lead to greater market discipline, improving managerial quality and reducing mismatch. ${ }^{14}$ This would in turn make it easier to adopt new technologies.

24. Lower barriers to firm exit can also reduce mismatch. By raising exit costs and thus preventing the winding down of low productivity firms, strict bankruptcy legislation can result in labour, particularly high-skilled workers, being trapped in inefficient firms and jobs that are not sufficiently challenging. This would in turn restrict the ability of high productivity firms to innovate and grow given a fixed pool of highskilled workers. ${ }^{15}$ Another link between bankruptcy legislation and skills could be through the ability of talented people to become entrepreneurs. For example, Neira (2014) finds that low recovery rates of loans, proxied by bankruptcy efficiency, can lead to a misallocation of skills as high-skilled individuals fail to become entrepreneurs and this could explain one fourth of cross-country differences in multi-factor productivity.

\subsubsection{Housing policies}

25. One potential barrier to labour mobility and the efficient allocation of skills in an economy is low rates of residential mobility. Residential and geographical mobility contribute to the efficient matching of jobs and the allocation of human resources within the labour market (Henley, 1998). Permanent shocks requiring a reallocation of production factors, such as sector and structural changes related to globalisation

13 The effectiveness of this channel will depend on whether there are also low barriers to firm exit.

14 There is evidence that there is a negative relationship between under-skilling and managerial quality (Adalet McGowan and Andrews, 2015). Bloom et al. (2014) has identified 4 possible determinants of managerial quality: i) competition; ii) regulations affecting product and labour markets; iii) ownership structure (e.g. managerial quality is highest in MNEs and lowest in family managed firms); and iv) education.

15 Acemoglu et al. (2013) show that policy intervention such as R\&D tax subsidies are only truly effective if policy-makers can encourage the exit of "low-type" incumbent firms, in order to free-up R\&D resources (i.e. skilled labour) for innovative "high-type" incumbents and entrants. 
or technological progress could lead to differences in regional supply and demand (Janiak and Wasmer, 2008). This would, in turn, require high geographical mobility to broaden the job search to new areas and increase the probability of finding a suitable job (Büchel and Van Ham, 2003; Hensen et al., 2009).

26. Across OECD countries, there is a positive correlation between residential mobility and worker reallocation rates (Figure 3), which is significant given that skill mismatch is related to productivity via the reallocation channel. Policy interventions in housing markets may affect geographical and, in turn, labour mobility and could give rise to mismatches and other inefficiencies in these markets (Andrews et al., 2011; van der Vilst et al., 2003). For example, high transactions costs on buying and selling of dwellings (e.g. stamp duties, registration fees, etc.) may create lock-in effects in the housing market, with implications for residential and job mobility (Oswald, 1999; Van Ommeren and Van Leuvenstein, 2005). Stringent rental regulations may lower residential construction and reduce the mobility of incumbent tenants, thus lowering residential mobility (Sims, 2007; Lind, 2001). Housing market interventions which limit the supply of housing, such as restrictive land use regulations and building costs, can also constrain residential mobility (Caldera Sánchez and Johansson, 2011).

Figure 3. Residential mobility and worker reallocation rates

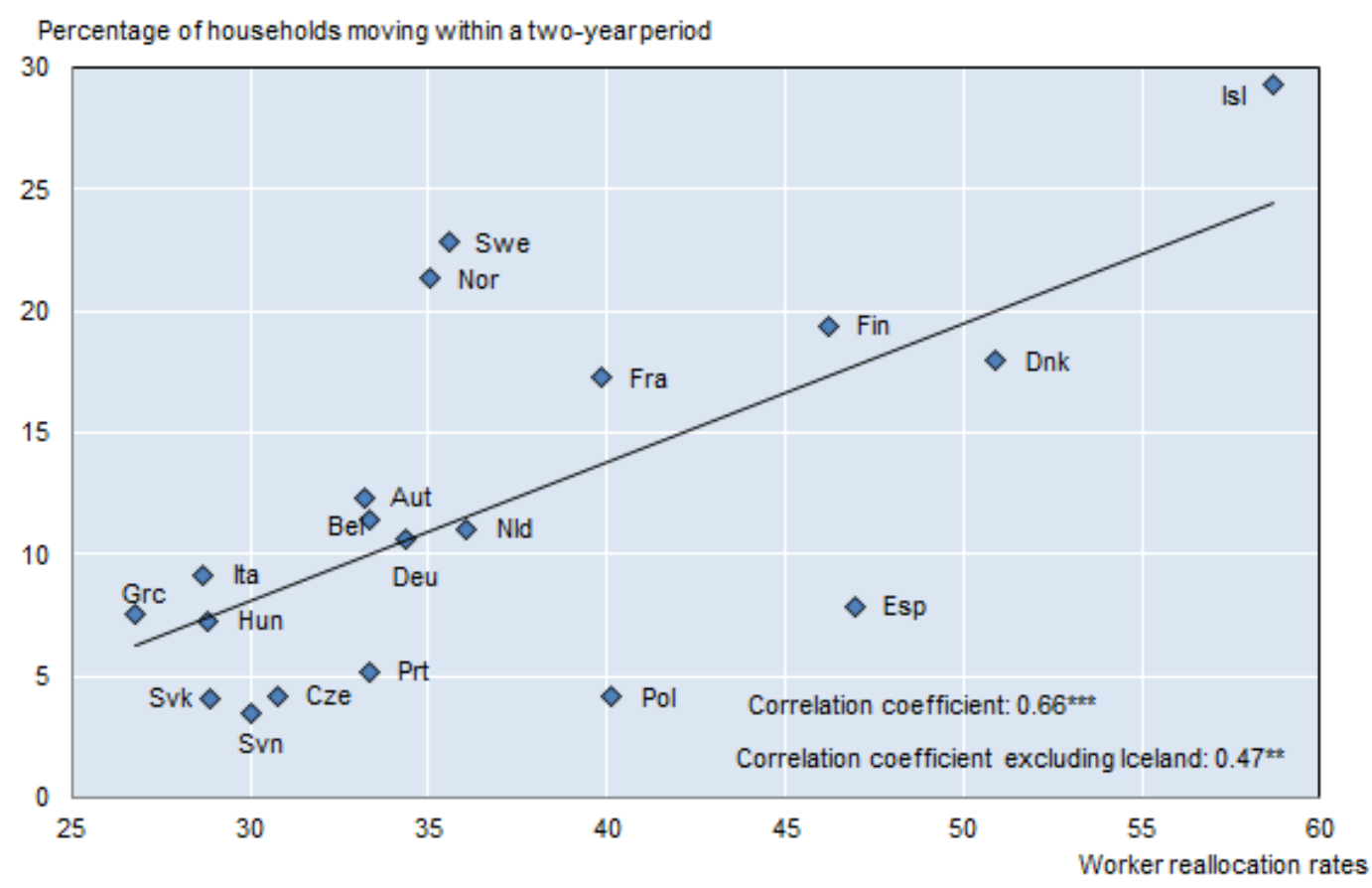

Notes: Worker reallocation rates are country averages of reallocation rates (hiring and firing rates) expressed in percentage of total dependent employment (adjusted for industry composition). The data are sourced from OECD (2010) and refer to 2000-07 except for Austria, Iceland, Slovenia: 2002-07; Canada, Denmark, France, Germany, Italy, Portugal, Sweden and the United States: 2000-06; the Czech Republic: 2001-07; Greece, Hungary, Ireland, Spain: 2000-05; Norway: 2000-04; Poland: 2004-05; the Slovak Republic: 2002-06; and Turkey: 2007. Residential mobility data are from Andrews et al. (2011) based on 2007 EU-SILC Database, on HILDA for Australia, AHS for the United States and SHP for Switzerland. ${ }^{* *}$ denotes statistical significant at $1 \%$ level; ${ }^{* \star}$ denotes statistical significant at $5 \%$ level.

Source: Andrews et al. (2011) and OECD (2010), Employment Outlook, Paris. 


\subsubsection{Labour market and education policies}

27. Besides EPL, other aspects of labour market institutions may also explain skill mismatch. For example, in response to changing demand for skills, firms need to adjust wages or labour force composition to avoid mismatch. ${ }^{16}$ At the same time, institutional settings (access to education, education policies, more rigid labour markets and higher labour market segmentation) may explain the different nature of skill mismatch within Europe (European Commission, 2013; Boheim et al., 2008).

28. Rigid wage-setting institutions may prevent the adjustment of wages to skill mismatch. Ideally, mismatch should result in a wage adjustment as it affects skill-acquisition decisions. However, some collective bargaining arrangements, such as high union density combined with a broad coverage of collective agreements, are associated with more homogeneous pay systems and lower wage differentials across firms (OECD, 2004), which in turn could affect mismatch.

29. Skill gaps are one of the key determinants of training investment made by firms and workers (McGuinness and Ortis, 2014). Given the changing face of the labour market, both workers who are just entering the labour force and those that are already in the workforce have to be willing to learn new skills. Adult learning and training are important to address such new skill requirements driven by technological change as well as skill loss over time. There is some evidence that work-related training can decrease the gap between skills acquired during formal education and those required on the job (Arulampalam et al., 2004) and reduce mismatch (van Smoorenburg and van der Velden, 2000). ${ }^{17}$

\section{Empirical approach and data}

\subsection{Empirical model}

30. The empirical model to study the links between skill mismatch, individual and job characteristics and policies is based on a three-step approach. First, the effect of individual and job characteristics on mismatch is analysed using a pooled cross-country logit model. Second, the role of policies is explored by augmenting this baseline model with country-level policies. Finally, the heterogeneous effects of policies on skill mismatch (e.g. the effect of policies on the mismatch of the youth) are explored, to give additional insight into the channels and serve as a robustness check.

\subsubsection{Mismatch and individual and job characteristics}

31. The link between individual background characteristics and mismatch is investigated by estimating the following cross-country binomial logit specification:

$$
S M M_{i}=\Phi\left(\delta_{1}+\delta_{2} I_{i}+\delta_{3} C_{c}+\epsilon_{i}\right)
$$

where $\Phi$ is the normal distribution, $i$ denotes an individual and $c$ denotes country and $\mathrm{SMM}_{\mathrm{i}}$ denotes the probability that an individual $i$ is mismatched (SMM $=1$ if an individual $i$ is over- or under-skilled), and $\mathrm{C}$ denotes country-specific control variables, including total national income. A country-by-country estimation is also considered to explore cross-country differences in the determinants of mismatch (Appendix B).

16 Mismatch is higher in countries with low expenditures in active labour market programmes (Marsden et al., 2002) and more rigid labour markets, proxied by a subjective assessment of the negative impact of labour regulation on business activities (European Commission, 2013). 2011; Heckman and Carneiro, 2003). Hence, better targeting training to low-skilled workers is important. 
32. The explanatory variables include a vector of individual characteristics, $I$, which are likely to influence mismatch. These include: age category (15-24, 25-34, 35-44, 45-54 and 55-65), gender (1 if the person is male, 0 otherwise), nationality ( 1 if national, 0 if foreign-born), marital status ( 1 if married, 0 otherwise), education (categorical variable measuring if the person has lower secondary, upper secondary, post-secondary or tertiary education), firm size (1-10, 11-50, 51-250, 251-999 and 1000+), contract type (indefinite, fixed and temporary agency/apprenticeship/no contract), fulltime (1 if the person is employed full-time, 0 otherwise) and organisation type ( 1 if private firm, 0 if public sector or NGO). ${ }^{18}$

\subsubsection{Mismatch and policies}

33. The empirical approach also exploits cross-country variation in policies and institutions to assess the role of policy settings in explaining skill mismatch. As discussed in Section 3.2, there is scope for a range of framework, housing and education policies to potentially influence mismatch. To consider these policies, the following cross-country specification is estimated:

$$
S M M_{i, c}=\Phi\left(\delta_{1}+\delta_{2} I_{i, c}+\delta_{3} P_{c}+\delta_{4} C_{c}+\epsilon_{i, c}\right)
$$

where SMM is a measure of whether individual $i$ in country $c$ is over- or under-skilled, $I$ denotes the vector of individual characteristics outlined above, $P$ denotes country-specific policies and $C$ denotes countryspecific control variables, including total national income.

34. The estimation of equation (2) treats policies as exogenous factors affecting mismatch, but there may be reason to be concerned about endogeneity. Given that data on skill mismatch are only available for one point in time, we cannot include country fixed effects and country level policies at the same time in the above regression model. Since the number of survey respondents within 2-digit industries is very small, it is also difficult to exploit alternative estimation strategies, such as the Rajan-Zingales approach which interacts country level policies with relevant industry level characteristics, while controlling for country fixed effects. Thus, even more caution should be applied than usual in attaching a causal interpretation to the results.

35. Another reason for caution is that to the extent that some of the policy-related variables are correlated among themselves (Table D1 in Appendix D), these variables are included one at a time in the baseline specification so as to avoid multicollinearity problems. Hence, the baseline results reflect bivariate correlations between mismatch and the considered policy, rather than causal links. The results are, however, broadly robust to including several less interrelated policy variables at a time and are shown as a robustness check in Table D2 in Appendix D.

36. The literature on skill mismatch tends to concentrate on the negative consequences of overskilling in terms of lower productivity, lower job satisfaction and waste of investment made in education. Under-skilling, on the other hand, can lead to "gains" in terms of higher wage premium and status compared to what would have been achieved at a well-matched job. Hence, although both types of mismatch are considered together in the subsequent analysis, separate analysis for the components of mismatch is included in Appendix C. However, the relatively low share of under-skilling, which results in a small number of observations for identification, suggests that these results should be interpreted with caution. 


\subsubsection{Heterogeneous effects of policies on mismatch}

37. The effect of policy-related factors on mismatch may vary depending on individual and job characteristics. To look into such effects in depth, we finally analyse the differential effect of policy-related factors on different exposure variables. For example, many of the housing policies have a stronger effect on the residential mobility of younger households, who are more likely to move (Caldera Sánchez and Andrews, 2011). Similarly, such policies could increase the likelihood of mismatch disproportionately for young workers. Such an analysis can also serve as a robustness check to the results from the baseline analysis.

38. To investigate these hypotheses, the following model is estimated:

$$
S M M_{i, c}=\Phi\left(\delta_{1}+\delta_{2} I_{i, c}+\delta_{3} P_{c}+\delta_{4} P_{c} * \operatorname{Exp}_{i}+\delta_{5} \operatorname{Exp}_{i}+\delta_{6} C_{c}+\epsilon_{i, c}\right)
$$

where SMM is a measure of whether individual $i$ in country $c$ is over- or under-skilled, I denotes the vector of individual characteristics outlined above, $\mathrm{P}$ denotes country-specific policies and $\mathrm{C}$ denotes countryspecific control variables such as total national income. Exp refers to a binary variable if the individual is younger than 44 years old (Young) and 0 otherwise. ${ }^{19}$ The coefficient $\delta_{4}$ measures the differential effect of a given policy on young workers compared to old ones (or other exposure variables), while $\delta_{3}$ measures the average effect of the policy. An alternative exposure variable, a new measure of managerial quality in the 1-digit industry where the individual is employed, is also considered. This indicator is derived from PIAAC, based on the average literacy scores of managers in each country-industry cell. Since this is an industry-level variable, country fixed effects are also included when using this exposure variable.

\subsection{Policy and other indicators}

39. The data for policy indicators come from a variety of sources (see Table A1 in Appendix A). Indicators for the stringency of labour and product markets are from the OECD, product market regulation (PMR) and OECD, employment protection legislation (EPL) databases. The PMR data refer to the economy-wide regulations for $2008 .{ }^{20}$ Cost of closing a business, a proxy for the strictness of bankruptcy legislation, is from World Bank, Doing Business Indicators (Figure A1 in Appendix A).

40. The housing policy indicators, transaction costs affecting the buying and selling of dwellings, strictness of rent control and tenant-landlord regulations in the private rental market (Figures A2 and A3 in Appendix A) as well as the responsiveness of housing supply to prices, are sourced from Andrews, et al. (2011). Given the evidence that cumbersome land use and planning regulations are associated with a less responsive housing supply (Caldera Sánchez and Johansson, 2011), a relevant policy measure is also considered. Data for the number of days to obtain a building permit, which can affect the housing supply, are sourced from World Bank, Doing Business Indicators (Figure A4 in Appendix A).

41. The coverage rate of collective bargaining agreements refer to the percentage of workers who are covered by collective bargaining agreements, regardless of whether or not they belong to a trade union and are sourced from OECD, Going for Growth Database. Participation in lifelong learning data is derived from two separate sources: Eurostat and the Survey of Adult Skills (2012). Finally, the data for managerial quality is derived from PIAAC (see above).

19 Other exposure variables, such as firm size and firm dynamics (i.e., whether the firm expanded or contracted its employment) were also considered but did not yield any significant results.

The 2008 data have been updated with a new methodology in 2013. See Koske et al. (2015) for details. 


\section{Empirical results}

42. This section first presents the empirical results concerning the effect of individual characteristics on skill mismatch across countries. It then moves on to the effects of policies on mismatch and their economic significance. Finally, heterogeneous effects of policies on mismatch and robustness checks are discussed.

\subsection{The effect of individual and job characteristics on skill mismatch}

43. Table 1 reports the baseline results of estimating Equation (1) for the probability of skill mismatch (Column 1), over-skilling (Column 2) and under-skilling (Column 3) across countries. A similar analysis is conducted at the country level and the country-by-country results are presented in Appendix B (Tables B1-B3). The reported coefficients are marginal effects and can be interpreted as the average impact across OECD countries of a unit change in the explanatory variable on the probability of skill mismatch. These changes are relative to the probability of skill mismatch of the excluded individual: married, male, native-born, young worker with low education attainment, working in a small firm on indefinite contracts. ${ }^{21}$

44. Across OECD countries, females are less likely to be mismatched in terms of skills (Column 1). Furthermore, this is mainly driven by the fact that females are less likely to be over-skilled (Column 2), while the relationship between gender and under-skilling is not significant. These results are in line with Quintini (2011), who uses a different dataset and also finds that women are less likely to be over-qualified (OECD , 2013). Both of these results are contrary to the assumption that women are more likely to be overskilled/qualified because of family constraints or the wish to improve their work-life balance.

45. Table 1 shows that the probability of skill mismatch is higher for immigrants (Column 1). Foreign-born workers are more likely to be mismatched in terms of skills than their native counterparts in a number of OECD countries except in the Slovak Republic where the opposite is true (Table B1 in Appendix B). Looking at the components of mismatch reveals that immigrants are less likely to be overskilled (Column 2), while they are more likely to be under-skilled (Column 3). ${ }^{22}$ As discussed in Section 3.1.2, the heterogeneity of the migrant population could lead to different conclusions on the relationship between being foreign-born and the probability of skill mismatch. However, the relatively low share of migrants in the sample makes a more differentiated analysis of this link difficult.

46. Consistent with the literature, skill mismatch decreases with age as workers gain more experience and/or move into jobs that have a better fit with their skill levels (Table 1, Column 1). Additionally, it could be the case that workers whose over-skilling is beneficial for firm productivity are more likely to be promoted to a job matching their skills as they get older. Furthermore, older workers are less likely to be over-skilled (Column 2) and more likely to be under-skilled (Column 3) as skills learned at school tend to depreciate and to become obsolete over time. Young people, on the other hand, are more likely to be overskilled as they may be in entry-level jobs where skill demands do not meet their actual skills.

21 The choice of the base category can make the interpretation of some of the results difficult, but the results are robust to changing the base categories. For example, when workers aged 35-44 working in mediumsized firms are excluded, the relationship between age, firm size and mismatch remains robust.

The relationship between migrant status and over-skilling differs from the finding in the literature that immigrants are more likely to be over-qualified. The low overlap between over-qualification and overskilling suggests that even if employers are not able to recognize foreign qualifications (resulting in overqualification), they could be successful in utilising the skills of the migrant workers effectively. 
ECO/WKP(2015)28

Table 1. The effect of individual characteristics on skill mismatch: pooled cross-country regressions

Marginal effects

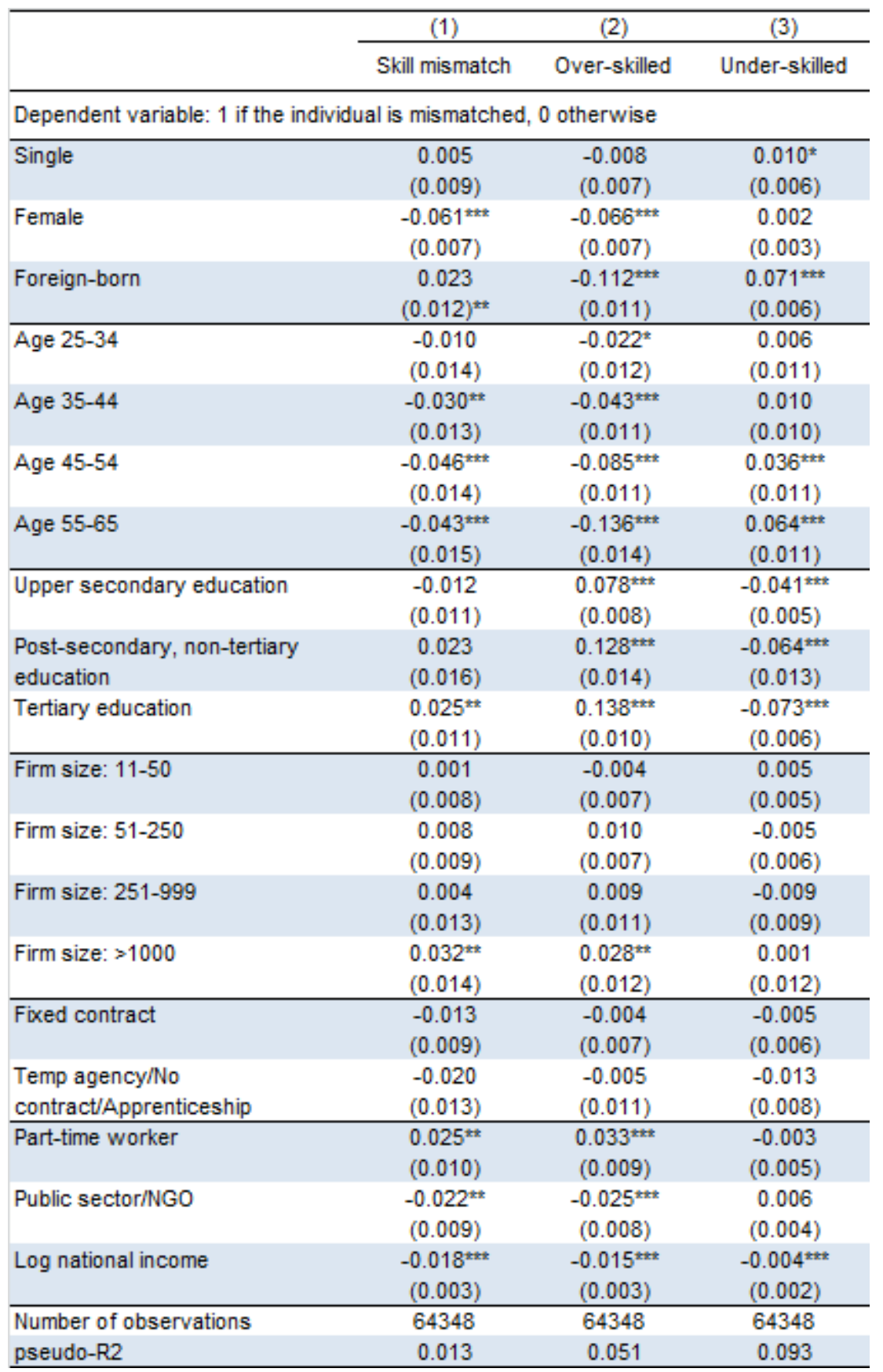

Notes: Estimates from logit regressions. Values are marginal effects. The coefficients correspond to the impact of a change in the explanatory variable on the probability of mismatch at the mean of the independent variables. Regressions include as controls age, marital and migrant status, gender, level of education, firm size, contract type, a dummy for working full-time and working in the private sector. Robust standard errors in parentheses. ${ }^{* * *}$ denotes statistical significance at the $1 \%$ level, ${ }^{* *}$ significance at the $5 \%$ level, ${ }^{*}$ significance at the $10 \%$ level.

Source: OECD calculations based on the Survey of Adult Skills (2012).

47. On average across OECD countries, workers with tertiary education are more likely to have skill mismatch compared to the base category of workers with lower secondary education (Column 1), but 
cross-country differences emerge (Table B1 in Appendix B). In six OECD countries (Canada, Italy, Japan, Norway, Poland and the Slovak Republic), the positive relationship between tertiary education and skill mismatch is especially strong, possibly suggesting that high-skilled labour is misallocated. However, in 12 of the 22 OECD countries in the sample, this relationship is insignificant, while in Austria, workers with tertiary education are less likely to have skill mismatch. Looking at the components of mismatch shows that over-skilling increases with the level of education for all categories (Column 2), while the opposite is true for under-skilling (Column 3). This suggests that higher levels of education across OECD countries are effective at providing basic levels of skills required for a number of jobs. At the same time, the higher rates of over-skilling amongst more educated workers could be a result of firm decisions.

48. Workers in large firms (more than 1000 employees) are more likely to be mismatched in terms of skills, but this is mainly driven by over-skilled workers (Columns 1 and 2). One potential explanation for this could be that larger firms can identify and anticipate future skill needs and may choose to hoard overskilled workers. The link between firm size and under-skilling is negative but insignificant (Column 3). However, it is consistent with the analysis in Adalet McGowan and Andrews (2015) that shows that larger firms are better managed and that better managerial quality can account for the association between underskilling and firm productivity. ${ }^{23}$

49. On average across OECD countries, there is no significant relationship between mismatch and whether a worker is on a permanent or a temporary contract, which is in line with the literature. However, there are some cross-country differences. Workers on fixed-term contracts relative to indefinite contracts are more likely to be mismatched in Ireland, Korea, Poland and Sweden, while the reverse is true in Germany (Table B1). Part-time workers are more likely to be mismatched (Column 1). Occupational choices in part-time work could be more limited, raising the probability of over-skilling and a switch from full-time to part-time employment could entail occupational downgrading (Sparreboom, 2014; Connolly and Gregory, 2008). ${ }^{24}$ Finally, workers in the public sector are less likely to be mismatched in terms of skills (Column 1). Looking at the components shows that public sector employees are more likely to be over-skilled than their private firm counterparts, perhaps reflecting the fact that these jobs are more homogeneous (Column 2).

\subsection{The effect and economic significance of policy-related factors on skill mismatch}

50. The relationship between policies and skill mismatch is explored using three main approaches. Table 2 reports the baseline results of the pooled regressions that explore the effects of different policyrelated factors on skill mismatch obtained from the estimation of Equation (2). The different specifications control for a similar set of individual and job characteristics as above but the estimated coefficients are not reported for the sake of brevity. The relationship of policies and the components of mismatch are also explored (see Tables $\mathrm{C} 1$ and $\mathrm{C} 2$ in Appendix $\mathrm{C}$ ). ${ }^{25}$ To understand the economic significance of the effect of policy-related factors on skill mismatch and the reductions in mismatch that could be associated with policy reform, Figures 4 and 5 show how different policy scenarios influence mismatch based on the estimates in Table 2 (see Figure $\mathrm{C} 1$ for more detailed results on selected policies). The dot is the average probability to have mismatch evaluated at the median level of the policy and individual characteristics. The

23 When managerial quality is controlled for (Section 5.2), the positive relationship between over-skilling and firm size remains significant. One potential explanation for this result could be measurement error as the number of very large firms is small in some countries in the sample.

24 Part-time workers are more likely to be mismatched in Australia, Austria, Canada, Denmark, Germany, the Netherlands, Norway and the Slovak Republic (Table B1).

25 The links between all policies (except the cost of obtaining a permit) and mismatch continue to hold for over-skilled workers, while the results are less robust for under-skilling. This could be due to measurement error since the share of under-skilled workers is quite low across OECD countries (Figure 1). 
distance between the Min/Max of the relevant policy indicator and the median is the change in the probability of skill mismatch associated with the respective policy change. ${ }^{26}$ Finally, Table 3 reports the potential gains for labour productivity from policy reforms that reduce skill mismatch, although as discussed above, these estimates should be treated with some caution. The results contribute to opening up the black box of the framework policies-productivity nexus by considering skill mismatch as one channel through which such policies can affect productivity. However, the effects presented in Table 3 cannot be cumulated as they reflect bivariate correlations rather than causal links.

51. To the extent that skill mismatch is related to productivity through both within-firm and betweenfirm factors (see Adalet McGowan and Andrews, 2015), it is important to consider policies and factors that impose frictions to the efficient reallocation of labour, restrict the entry of more productive firms and prevent the exit of less productive firms as potential determinants of skill mismatch. ${ }^{27}$

\subsubsection{Well-designed framework policies lower skill mismatch}

52. Well-designed framework policies are associated with lower skill mismatch (Panel A of Table 2). While the finding with respect to employment protection legislation (EPL) is somewhat standard in the literature (Section 3.2.1), the link between mismatch and other framework conditions is more novel.

53. Stringent labour market regulations, both for permanent and temporary employees, are associated with higher mismatch as they reduce labour market flexibility and the ability of firms to adapt to shocks or changing skill needs (Columns 1 and 2 in Table 2, Panel A). However, the effect is stronger for regulations on permanent employers compared to temporary workers, which is in line with the literature that suggests that strict firing rules are one of the most important channels through which EPL can affect mismatch. In terms of economic significance, reducing the stringency of regulations affecting labour markets (for permanent employees) from the maximum levels to the median levels is associated with roughly a 3 percentage point reduction in skill mismatch and around 1 percentage point implied gain in labour productivity (Figure 4; Table 3). Additional analysis in Appendix C shows the potential reduction in skill mismatch associated with reducing the stringency of EPL to best practice levels (Figure C1).

54. Policy and institutional settings with low barriers to firm entry and strong competitive pressures more generally, such as lower product market regulations (PMR), is associated with a lower probability of skill mismatch (Column 3 in Table 2, Panel A). Reducing the stringency of product market regulations from the maximum level in Poland to the median levels is associated with a 3 percentage point reduction in mismatch (Figure 4). See Figure C1 in Appendix C for estimates of the potential impact on skill mismatch associated with policy reforms that reduce PMR to best practice level.

\footnotetext{
26 The reported probabilities are computed at the median, max or min of the policy variables and the mean of the rest of the explanatory variables.

27 The baseline specifications include one policy-related variable at a time. See Table D2 in Appendix D for specifications where several less interrelated policy-related variables are included together.
} 
Table 2. The effect of policy-related factors on skill mismatch

Marginal effects

\begin{tabular}{|c|c|c|c|c|c|}
\hline & (1) & (2) & (3) & (4) & (5) \\
\hline \multicolumn{6}{|c|}{ Dependent variable: 1 if the individual is mismatched, 0 otherwise } \\
\hline Panel A: Framework policies & $\begin{array}{l}\text { Employment } \\
\text { protection } \\
\text { legislation for } \\
\text { permanent } \\
\text { workers }\end{array}$ & $\begin{array}{l}\text { Employment } \\
\text { protection } \\
\text { legislation for } \\
\text { temporary } \\
\text { workers }\end{array}$ & $\begin{array}{l}\text { Product market } \\
\text { regulation }\end{array}$ & $\begin{array}{l}\text { Cost of closing a } \\
\text { business }\end{array}$ & \\
\hline \multirow{2}{*}{ Policy-related factors } & $0.045^{* * *}$ & $0.022^{* \pm *}$ & $0.041^{\text {t** }}$ & $0.005^{* * *}$ & \\
\hline & $(0.008)$ & $(0.003)$ & $(0.015)$ & $(0.001)$ & \\
\hline Number of observations & 64348 & 64348 & 64348 & 64348 & \\
\hline pseudo-R2 & 0.013 & 0.011 & 0.010 & 0.013 & \\
\hline Panel B: Housing policies & $\begin{array}{c}\text { Transaction } \\
\text { costs }\end{array}$ & Rent control & $\begin{array}{l}\text { Tenant-landlord } \\
\text { regulations }\end{array}$ & $\begin{array}{l}\text { Cost of obtaining } \\
\text { a building permit }\end{array}$ & $\begin{array}{l}\text { Responsiveness } \\
\text { of housing supply }\end{array}$ \\
\hline \multirow{2}{*}{ Policy-related factors } & $0.007^{ \pm * 2}$ & $0.016^{* * 2}$ & $0.021^{\text {*** }}$ & $0.001^{* \pm *}$ & $-0.052^{* \pm *}$ \\
\hline & $(0.001)$ & $(0.003)$ & $(0.003)$ & $(0.000)$ & $(0.010)$ \\
\hline Number of observations & 64348 & 58344 & 60811 & 64348 & 54370 \\
\hline pseudo-R2 & 0.011 & 0.011 & 0.012 & 0.010 & 0.015 \\
\hline Panel C: Other policies & $\begin{array}{c}\text { Coverage rate of } \\
\text { collective } \\
\text { bargaining } \\
\text { agreements }\end{array}$ & $\begin{array}{l}\text { Participation in } \\
\text { lifelong learning } \\
\text { (PIAAC data) }\end{array}$ & $\begin{array}{l}\text { Participation in } \\
\text { lifelong learning } \\
\text { (EU data) }\end{array}$ & Managerial quality & \\
\hline \multirow{2}{*}{ Policy-related factors } & $0.001^{\text {tat }}$ & $-0.002^{\text {*t* }}$ & $-0.001^{* * *}$ & $-0.001^{* * *}$ & \\
\hline & $(0.000)$ & $(0.000)$ & $(0.000)$ & $(0.000)$ & \\
\hline Number of observations & 64348 & 64348 & 44274 & 63340 & \\
\hline pseudo-R2 & 0.012 & 0.012 & 0.011 & 0.012 & \\
\hline
\end{tabular}

Notes: See Section 4.2 and Table A1 for detailed explanations of the policy variables. Estimates from logit regressions. Values are marginal effects. The coefficients correspond to the impact of a change in the explanatory variable on the probability of mismatch at the mean of the independent variables. Each column in each panel includes one policy-related variable at a time. Regressions include as controls age, marital and migrant status, gender, level of education, firm size, contract type, a dummy for working full-time and working in the private sector. Robust standard errors in parentheses. ${ }^{* *}$ denotes statistical significance at the $1 \%$ level, ${ }^{* *}$ significance at the $5 \%$ level, * significance at the $10 \%$ level.

Source: OECD calculations based on the Survey of Adult Skills (2012).

55. Panel A of Table 2 shows that policies that make it easier for firms to exit such as lower costs of closing a business are also associated with a lower probability of mismatch. Bankruptcy legislation that does not excessively penalise business failure can reduce the likelihood that valuable skills are trapped in inefficient firms. Reducing the stringency of bankruptcy legislation from its most restrictive level in Italy (where mismatch is very high; Figure 1) to the median level in Canada is associated with a 10 percentage point decrease in mismatch. This is particularly significant, given that the average level of mismatch is $22 \%$, and the implied gain to labour productivity from improving bankruptcy legislation is 3.6 percentage points (Table 3). See Figure $\mathrm{C} 1$ in Appendix $\mathrm{C}$ for estimates of the potential reduction in skill mismatch associated with policy reforms that lower the stringency of bankruptcy legislation to best practice level. 
Figure 4. The probability of skill mismatch and framework policies

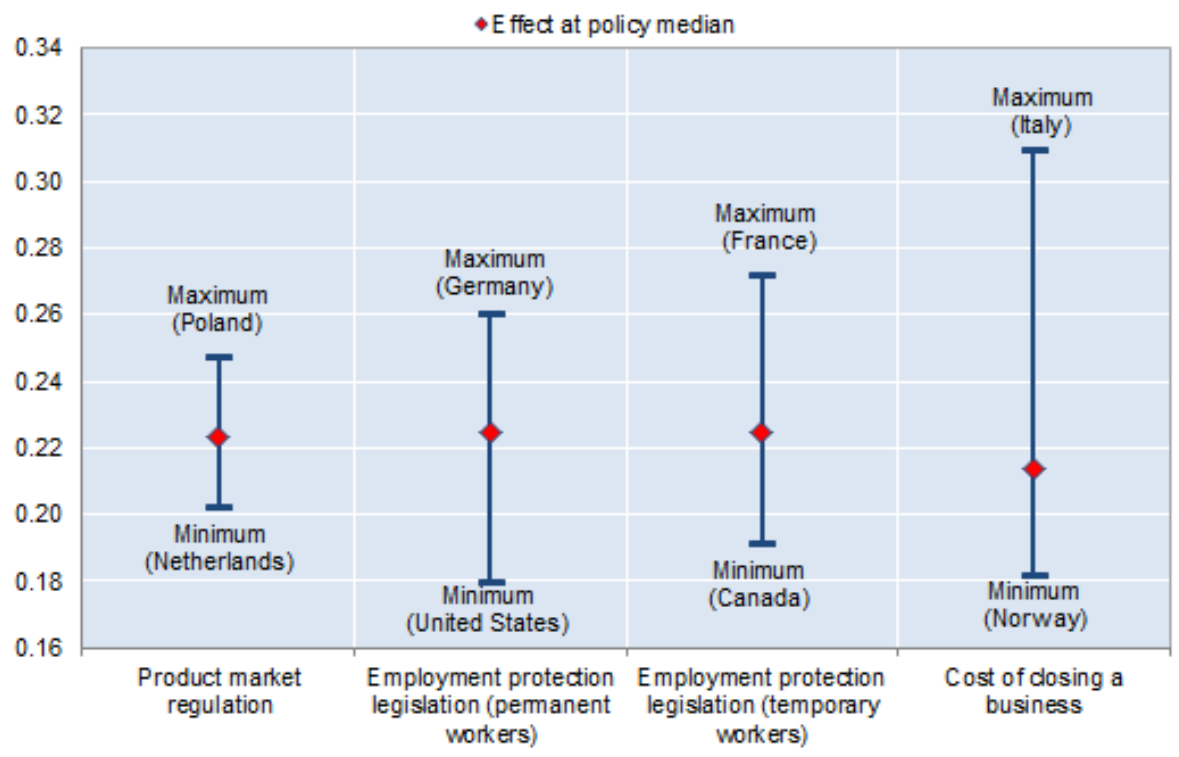

Notes: The dot is the average probability to have mismatch evaluated at the median level of the policy and individual characteristics, which include age, marital and migrant status, gender, level of education, firm size, contract type, a dummy for working full-time and working in the private sector. The distance between the Min/Max and the median is the change in the probability of skill mismatch associated with the respective policy change.

Source: OECD calculations based on the Survey of Adult Skills (2012).

\subsubsection{Barriers to mobility in housing markets exacerbate skill mismatch}

56. As discussed in Section 3.2.2, higher residential mobility is associated with lower worker reallocation rates and skill mismatch. Table 2 (Panel B) shows that policies that restrict mobility in housing markets might amplify skill mismatch by limiting labour mobility ${ }^{28}$ :

- Lowering transaction costs could reduce skill mismatch. By creating lock-in effects, transaction costs affecting the buying and selling of dwellings - e.g. transfer taxes (stamp duties, acquisition taxes), registration fees, notarial or other fees - can reduce residential mobility (Table 2, Panel B). The estimates in Figure 5 (Panel A) imply that reducing transaction costs from the highest level (Belgium) to the median level (Finland) is associated with a reduction in the probability of mismatch by around 7 percentage points, implying potential gains to labour productivity of 2.5 percentage points (Table 3). See Figure C1 in Appendix C for estimates of the potential reduction in skill mismatch associated with policy reforms that lower transaction costs to best practice level.

- Strict rent controls and rules governing tenant-landlord favouring tenants are associated with higher skill mismatch: The link between being a private renter and residential mobility can be improved through several policies, which would also improve matching of jobs and skills. Reducing rent controls from the level in the most restrictive country (Sweden) to that of the median (Canada), is associated with a reduction in the probability of skill mismatch by 5 percentage points (Figure 5, Panel A). Similarly, making rules governing tenant-landlord relations more landlord-friendly (by easing them from the most restrictive levels in Austria to the well as a negative and significant relationship between the rate of urbanisation and mismatch. 
median level in Japan) is associated with a 4.5 percentage point decrease in mismatch. The implied gain in labour productivity from implementing these policies are 1.6 percentage points (Table 3).

- Policies that restrict housing supply are associated with higher skill mismatch: A low price responsiveness of housing supply can reduce labour mobility by affecting the average availability of housing. The responsiveness of housing supply depends on geographical and urban characteristics as well as regulations on the use of land, which influence the allocation of land and housing to different uses. Specifically, the elasticity of housing supply is lower in countries where it takes longer to acquire a building permit, underscoring the importance of efficient landuse regulation and administration (Andrews et al., 2011). Indeed, reducing the number of days to obtain a building permit from its maximum level (Slovak Republic) to the median (the Netherlands), is associated with a two percentage points decrease in skill mismatch (Figure 5, Panel A) and a 0.7 percentage point implied gain in labour productivity.

Table 3. Estimated gains to labour productivity from policy reforms that reduce skill mismatch

Per cent increase in labour productivity from reducing policy distortion from sample maximum to median value

\begin{tabular}{|c|c|}
\hline Policy experiment & $\begin{array}{l}\text { Implied gain in } \\
\text { labour } \\
\text { productivity }\end{array}$ \\
\hline Framework policies & $\%$ pts \\
\hline $\begin{array}{l}\text { Reducing PMR from the maximum level (in Poland) to the sample median } \\
\text { level (in Italy) }\end{array}$ & 0.9 \\
\hline $\begin{array}{l}\text { Reducing EPL (permanent) from the maximum level (in Germany) to the } \\
\text { sample median level (in Norway) }\end{array}$ & 1.3 \\
\hline $\begin{array}{l}\text { Reducing the cost of closing a business from the maximum level (in Italy) to } \\
\text { the sample median level (in Canada) }\end{array}$ & 3.6 \\
\hline \multicolumn{2}{|l|}{ Housing policies } \\
\hline $\begin{array}{l}\text { Decreasing transaction costs from the maximum level (in Belgium) to the } \\
\text { sample median level (in Finland) }\end{array}$ & 2.5 \\
\hline $\begin{array}{l}\text { Decreasing rent control from the maximum level (in Sweden) to the sample } \\
\text { median level (in Canada) }\end{array}$ & 1.6 \\
\hline $\begin{array}{l}\text { Decreasing tenure security (i.e. tenant-landlord regulations) from the } \\
\text { maximum level (in Austria) to the sample median (in Japan) }\end{array}$ & 1.6 \\
\hline $\begin{array}{l}\text { Decreasing the days to obtain a building permit from the maximum level (in } \\
\text { the Netherlands) to the sample median level (in Australia) }\end{array}$ & 0.7 \\
\hline \multicolumn{2}{|l|}{ Other policies } \\
\hline $\begin{array}{l}\text { Reducing the coverage rate of collective bargaining agreements from the } \\
\text { maximum level (in Austria) to the sample median level (in the Czech } \\
\text { Republic) }\end{array}$ & 1.8 \\
\hline $\begin{array}{l}\text { Increasing participation in lifelong learning from the minimum level (in Italy) to } \\
\text { the sample median level (in Estonia) }\end{array}$ & 2.2 \\
\hline $\begin{array}{l}\text { Increasing managerial quality from the minimum level (in ltaly) to the sample } \\
\text { median level (in Canada) }\end{array}$ & 2.5 \\
\hline
\end{tabular}

Notes: Policy experiments are roughly equivalent to the impact of a 1 to 1.5 standard deviation change in the policy variables of interest on the probability of mismatch, except for PMR, EPL, participation in lifelong learning and managerial quality which are equivalent to the impact of a 2 to 2.5 standard deviation change. Estimates are based on logit regressions of probability of mismatch controlling for age, marital and migrant status, gender, level of education, firm size, contract type, a dummy for working full-time and working in the private sector (See Figures 4 and 5 ) and OLS regressions of labour productivity on skill mismatch.

Source: OECD calculations based on the Survey of Adult Skills (2012). 
ECO/WKP(2015)28

Figure 5. The probability of skill mismatch and other policies

Panel A. Housing policies

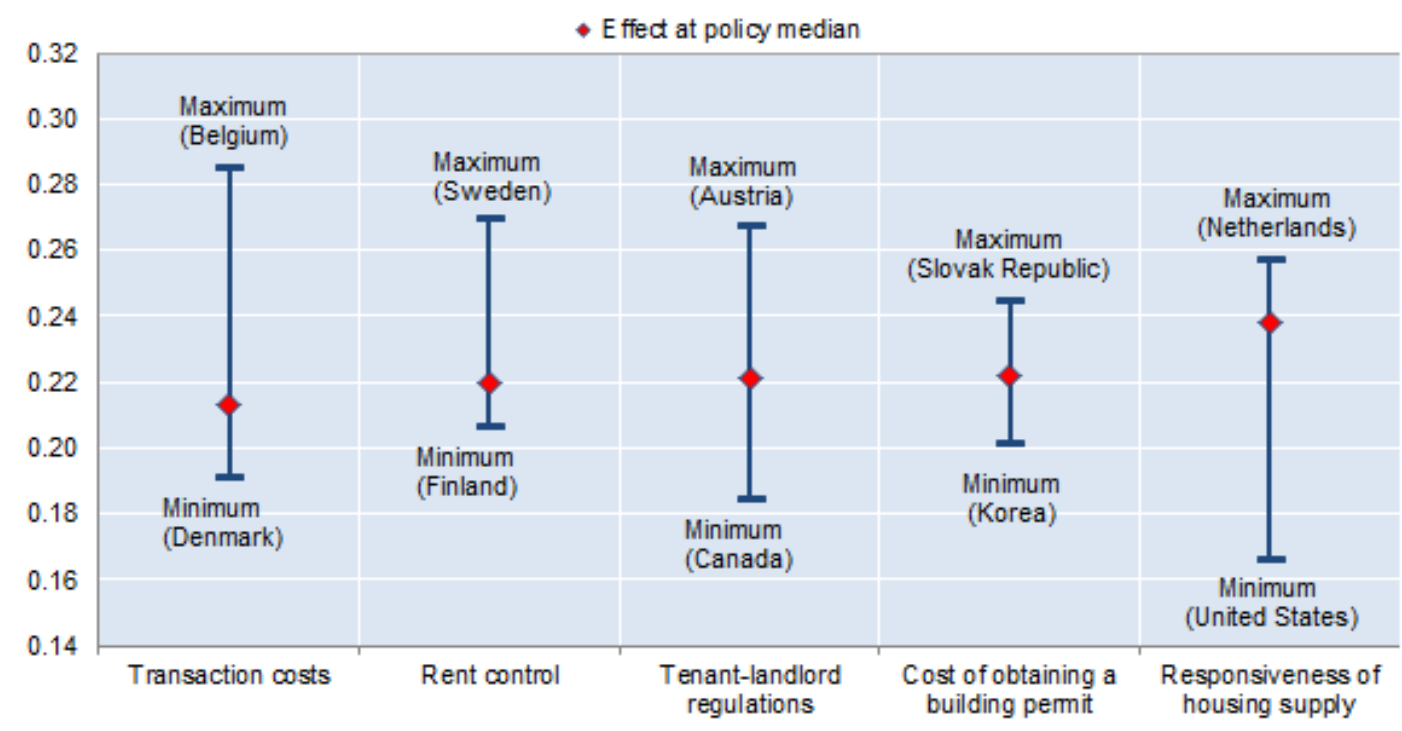

Panel B. Labour market and education policies

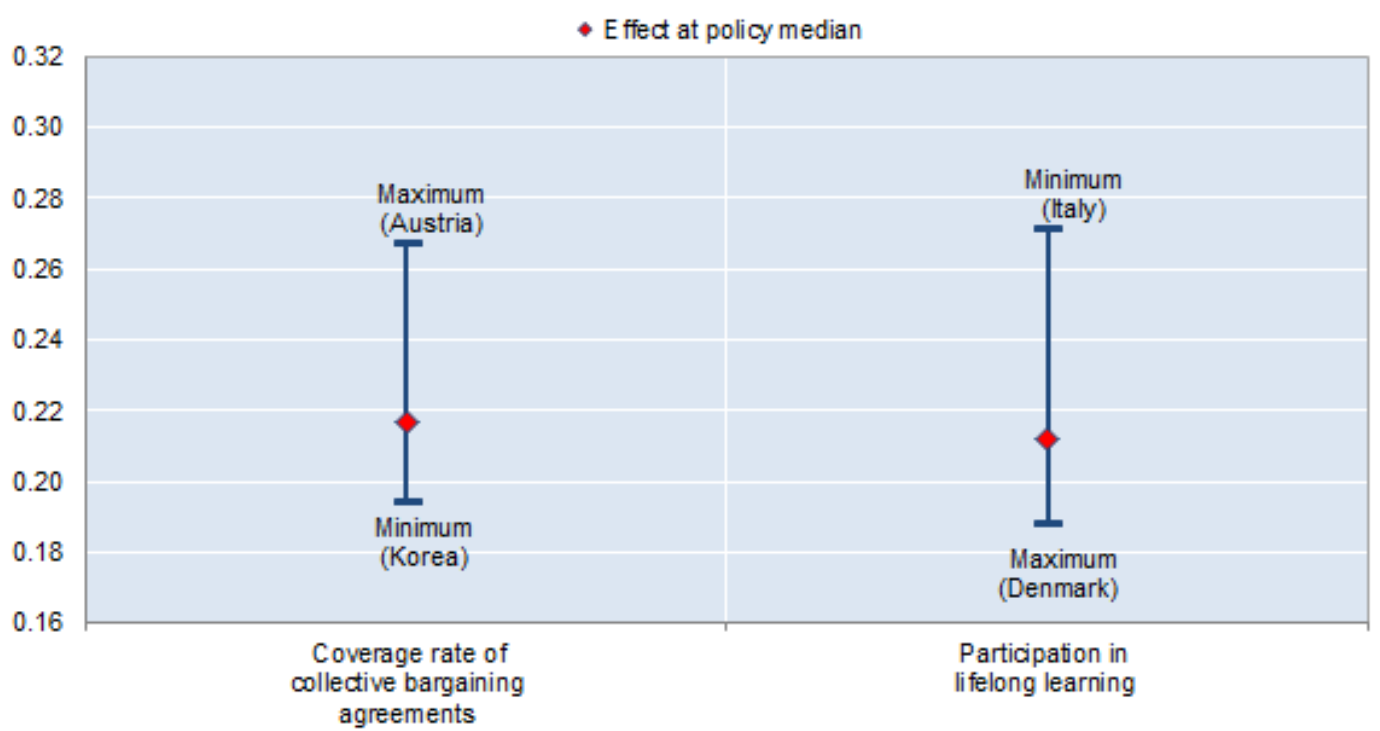

Notes: The dot is the average probability to have mismatch evaluated at the median level of the policy and individual characteristics, which include age, marital and migrant status, gender, level of education, firm size, contract type, a dummy for working full-time and working in the private sector. The distance between the Min/Max and the median is the change in the probability of skill mismatch with the respective policy change.

Source: OECD calculations based on the Survey of Adult Skills (2012). 


\subsubsection{Labour market and education policies can improve the matching of skills to jobs}

57. The returns to skills are lower in countries with more centralised wage bargaining systems ${ }^{29}$, which make it more difficult for employers to adjust wages according to skills. This may be the case because wage decisions are more likely to be based on observable characteristics, such as formal qualifications in such wage-setting systems (OECD, 2014a). The same is also true in countries with higher union density (Hanushek et al., 2013).

58. Table 2, Panel $\mathrm{C}$ shows that adding some degree of flexibility to at least allow scope for wage bargaining around some centrally-agreed standards to take place at the firm level may be desirable from the perspective of reducing mismatch. Lowering the coverage rate of collective bargaining agreements (percentage of workers who are covered by collective bargaining agreements, regardless of whether or not the belong to a trade union) from the high level in Austria to the median in the Czech Republic is associated with a reduction in the probability of mismatch of 5 percentage points and a 1.8 percentage point implied gain in labour productivity (Table 3 ).

59. Higher participation in lifelong learning is also associated with lower skill mismatch (Table 2, Panel C), reinforcing the importance of skills gained beyond formal qualifications through both on the jobtraining and opportunities for lifelong education and training as important instruments to reduce skill mismatch. ${ }^{30}$ The estimates in Figure 5 (Panel B) imply that increasing participation in lifelong learning from the lowest level (Italy) to the median (Estonia) is associated with a 6 percentage point reduction in mismatch), with a 2.2 percentage point implied gain in labour productivity (Table 3 ). There is evidence that under-skilled workers benefit from employer provided training, especially those of young workers (Messinis and Olekalns, 2007). However, high-skilled workers are more likely to participate in adult education and training, potentially highlighting the role for policies to increase the participation of lowskilled workers in adult learning (OECD, 2013).

\subsubsection{Better managerial quality could reduce skill mismatch and improve within-firm productivity}

60. Higher managerial quality improves within-firm and aggregate productivity (Bloom et al., 2012) largely through the application of modern HR practices (e.g. monitoring) and organisational restructuring, which promote more efficient technological adoption. Better managed firms may also be less susceptible to mismatch (see Section 3.1 for a discussion). Using industry-level data, Adalet McGowan and Andrews ( 2015) shows that higher managerial quality is associated with lower rates of under-skilling and higher within-firm productivity, and that differences in managerial quality can account for the negative association between under-skilling and within-firm productivity. Micro-data analysis also shows that higher managerial quality is associated with lower skill mismatch (Table 2, Panel C, Column 4). In terms of economic significance, improving managerial quality from its minimum levels in Italy to the median in Canada is associated with a decrease in skill mismatch by around 7 percentage points and a 2.5 percentage point implied gain in labour productivity (Table 3 ).

61. Policies that promote competition in product markets are a key determinant of managerial quality to the extent that they impose greater market discipline, which truncates the left tail of poorly managed and unproductive - firms (Bloom et al., 2014). Yet, product market competition may be less effective at facilitating the exit of poorly managed family-owned firms to the extent they are subsidised by their family

29 This refers to the level at which wage bargaining takes place (an indicator ranging from 1 to 5 , where 1 refers to bargaining taking place at the local or company level and 5 refers to bargaining taking place at the central of cross-industry level.

30 Participation in lifelong learning can be especially useful to workers who need to adapt to rapid changes in labour market demand and the arrival of new technologies. 
owners through cheap capital (Bloom et al., 2014). ${ }^{31}$ Hence, inheritance tax exemptions with respect to family firms might lower managerial quality. Indeed, in countries where inheritance tax exemptions for family firms are generous - e.g. the United Kingdom, France and Germany - the share of family-managed firms tends to be higher than in the United States, which has no substantial family firm exemptions (Bloom and Van Reenen, 2007). Hence, reducing such exemptions could increase the likelihood that badly managed family-owned firms change ownership, potentially raising aggregate productivity.

\subsection{Heterogeneous effects of policies on skill mismatch}

62. As discussed in Section 4.2, the cross-section nature of the mismatch data prevents the inclusion of country fixed effects when country level policies are included, making it more difficult to attach a causal interpretation to the results. One way to test the robustness of the baseline results is to analyse the differential effect of policy related factors on different groups in the sample, for example the youth. The results in Table 4 show the heterogeneous effects of policies on skill mismatch derived from the estimation of equation (3). The other control variables are not reported for the sake of brevity. The coefficient corresponding to the interaction term measures the differential effect of a given policy on young workers compared to old ones (or other exposure variables), while the coefficient on the policy measures the average effect of the policy. ${ }^{32}$ The reported coefficients differ from the baseline results in Tables 1 and 2 since they only refer to the average effects, rather than the marginal effects. This is due to practical reasons since it is not feasible to calculate the marginal effects, which are already difficult to calculate for interaction terms (for non-linear models such as logistic regressions), as the use of PIAAC data is limited by the available statistical tools. Hence, the reported average effect gives an indication of the sign of the relationship, but not the magnitude.

\subsubsection{Framework and housing policies disproportionately affect the youth}

63. Policies and institutions that distort reallocation mechanisms - such as stringent EPL - tend to disproportionately raise the incidence of skill mismatch amongst young people (Table 4; Column 1). This is consistent with the notion that efficient reallocation and labour market fluidity is particularly important for the job prospects of youth, to the extent that it provides scope to improve the quality of job-worker matching, which is naturally lower amongst young people due to their lack of experience (Davis and Haltiwanger, 2014). Given the tendency for skill mismatch to persist over time (Mavromaras et al., 2013), policies that promote efficient reallocation and improve the job-worker matching for youth are central to future productivity.

64. Moreover, many of the housing policies have a stronger effect on the residential mobility of younger households, who are more likely to move (Caldera Sánchez and Andrews, 2011). For example, high transaction costs and strict rental market regulations are associated with disproportionately higher mismatch amongst youth (Table 4, Columns 2-4), who are naturally more susceptible to mismatch and are likely to have less resources to finance the higher moving costs that these policies imply.

31 Family-owned firms are typically less well-managed, especially those managed by the oldest son of founders (Bloom and van Reenen, 2007). Selecting the CEO from among the small group of potential family members reduces the available pool of managerial ability and the incentives of the children of firm owners to acquire human capital.

32 An alternative specification, which includes the interaction of the policy variables with old as well as their interaction with the young, together with country fixed effects, is also considered and the results are broadly robust. These results are available on request. 
Table 4. Heterogeneous effects of policies on skill mismatch

Average effects

\begin{tabular}{|c|c|c|c|c|c|}
\hline & (1) & (2) & (3) & (4) & (5) \\
\hline & $\begin{array}{l}\text { Employment } \\
\text { protection } \\
\text { legislation } \\
\text { (EPL) }\end{array}$ & $\begin{array}{l}\text { Transaction } \\
\text { costs }\end{array}$ & Rent control & $\begin{array}{c}\text { Tenant- } \\
\text { landlord } \\
\text { regulations }\end{array}$ & $\begin{array}{c}\text { Managerial } \\
\text { quality and EPL }\end{array}$ \\
\hline \multicolumn{6}{|c|}{ Dependent variable: 1 if the individual is mismatched, 0 otherwise } \\
\hline \multirow[t]{2}{*}{ Policy-related factors } & 0.117 & 0.029 & 0.055 & 0.015 & \\
\hline & $(0.069)^{*}$ & $(0.007)^{* \pm *}$ & $(0.029)^{*}$ & $(0.032)$ & \\
\hline Policy-related factors ${ }^{*}$ Young & $\begin{array}{c}0.237 \\
(0.096)^{ \pm *}\end{array}$ & $\begin{array}{c}0.027 \\
(0.005)^{ \pm * *}\end{array}$ & $\begin{array}{c}0.104 \\
(0.039)^{* * *}\end{array}$ & $\begin{array}{c}0.136 \\
(0.040)^{* t *}\end{array}$ & \\
\hline Managerial quality & & & & & $\begin{array}{c}-0.012 \\
(0.004)^{ \pm \pm \pm}\end{array}$ \\
\hline $\begin{array}{l}\text { Managerial } \\
\text { quality }{ }^{\star} \text { Employment protection }\end{array}$ & & & & & $\begin{array}{c}0.008 \\
(0.003)^{* \pm *}\end{array}$ \\
\hline Country Fixed Effects & No & No & No & No & Yes \\
\hline Number of observations & 64348 & 64348 & 58344 & 60811 & 63340 \\
\hline pseudo-R2 & 0.013 & 0.010 & 0.012 & 0.011 & 0.024 \\
\hline
\end{tabular}

Notes: Each column includes one policy-related variable at a time. Estimates from logit regressions of equation (3). Values refer to the impact of a one-unit increase in the explanatory variable on the log-odds of the dependent variable, holding all other independent variables constant. Regressions include individual and job characteristics (See Table 3 ). Robust standard errors in parentheses. ${ }^{\star \star \star}$ denotes statistical significance at the $1 \%$ level, ${ }^{* *}$ significance at the $5 \%$ level, ${ }^{*}$ significance at the $10 \%$ level.

Source: OECD calculations based on the Survey of Adult Skills (2012).

\subsubsection{The benefits of high managerial quality could be lowered by inefficient reallocation of resources}

65. Independent of the level of managerial ability, policies may also shape the leeway for managers to reduce mismatch within firms. For example, stringent EPL is found to thwart the ability of managers to reduce mismatch for any given level of managerial quality (Table 4, Column 5), possibility reflecting excessive protection for incumbent workers in a firm, who might not be the best match for their job. Hence, efficient reallocation would strengthen the effect of policies on mismatch independent of managerial ability. In addition, reallocation-friendly policies can also magnify the gains to aggregate productivity from a given improvement in managerial quality by ensuring that the most effective managers are responsible for a larger share of the economy's resources (Bloom et al., 2013; Adalet McGowan and Andrews, 2015).

\subsection{Robustness checks and other policies}

66. The baseline results reported in Table 2 are broadly robust to a number of sensitivity tests. First, the results are robust to changing the threshold for defining whether an individual is mismatched (Box 1) to the $5^{\text {th }}$ and $95^{\text {th }}$ percentile as is the case in OECD (2013). Second, the baseline results are robust to including the mean proficiency score for each individual as an additional control as well as changing the omitted category for the control variables. Third, the inclusion of selected multiple policy variables is considered. Given the high correlation between some of the policy variables, to the extent possible, one variable from each of the 3 different sets of policies (framework, housing and other) that are less interrelated are included. The results presented in Table D2 show that despite some modest reductions in the coefficients, the baseline results are broadly robust. Finally, additional individual and job characteristics (e.g. household size) that may be relevant are considered, but not included in the baseline results, so as to maximise sample size, and the results continue to hold. 
67. Other policies that might be expected to be related to skill mismatch, for which data are available, were also considered, but did not yield any significant results. These include active labour market policies, an index of integration policies (the Migration Integration Policy Index), public expenditure on child care, cost of child care, tax on return to work, age of tracking and return to higher education.

\section{Conclusion}

68. This paper explores the link between skill mismatch and policies using micro data for 22 OECD countries. Utilising the data from the recent OECD Survey of Adult Skills, the main results suggest that differences in skill mismatch across countries are associated with differences in the policy environment. There are a few caveats to the analysis. First, only a subset of policies for which indicators are readily available are considered, but a range of other policies (e.g vocational education and training and the matching of university programmes to labour market demand needs) that are more difficult to measure may also matter. Second, causation is difficult to establish given data limitations: $i$ ) the data is available only at one point in time; and ii) due to high correlations between the policy variables, the baseline specification includes the policy variables one at a time (although the results are broadly robust to including several less interrelated policy variables). Nevertheless, a number of robust correlations between policy variables and skill mismatch emerge.

69. Results suggest that differences in skill mismatch across countries are associated with differences in the policy environment. After controlling for individual and job characteristics, skill mismatch is lower in countries with well-designed framework conditions that promote efficient reallocation, while housing policies that do not impede residential mobility also loom large. Lower mismatch is also associated with greater flexibility in wage negotiations and higher participation in lifelong learning as well as better managerial quality. Finally, some policies (e.g. EPL) are found to disproportionately affect the youth, which can have adverse implications for their lifetime labour market outcomes given persistence in skill mismatch, and thus lower future productivity. 


\section{REFERENCES}

Adalet McGowan, M. and D. Andrews (2015), "Labour Market Mismatch and Labour Productivity: Evidence from PIAAC Data", OECD Economics Department Working Papers, No. 1206.

Alba-Ramirez, A. (1993), "Mismatch in the Spanish Labour Market", Journal of Human Resources, Vol. 28, No. 2, pp. 259-278.

Aleksynska, M. and A. Tritah (2013), "Occupation-Education Mismatch of Immigrant Workers in Europe: Context and Policies", Economics of Education Review, Vol. 36, pp. 229-244.

Allen, J., M. Levels and R. van der Velden (2013), "Skill Mismatch and Skill Use in Developed Countries: Evidence from the PIAAC Study", Maastricht University, Research Centre for Education and the Labour Market Working Papers, No. 17.

Acemoglu, D., U. Akcigit, N. Bloom and W. Kerr (2013), "Innovation, Reallocation and Growth", NBER Working Papers, No. 18993.

Andrews, D., A. Caldera Sánchez and Å. Johansson (2011), "Housing Markets and Structural Policies in OECD Countries", OECD Economics Department Working Papers, No. 836.

Andrews, D. and F. Cingano (2014), "Public Policy and Resource Allocation: Evidence from Firms in OECD Countries”, Economic Policy, No. 29(78), pp. 253-296.

Arulampalam, W., A. Booth and M. Bryan (2004), "Training in Europe", Journal of the European Economic Association, Vol. 2, pp. 346-360.

Battu, H. and P.J. Sloane (2004), "Over-Education and Ethnic Minorities in Britain", The Manchester School, Vol. 72, No. 4, pp. 535-559.

Bloom, N. and J. Van Reenen (2007), "Measuring and Explaining Management Practices Across Firms and Countries", Quarterly Journal of Economics, 122 (4), pp. 1351-1408.

Bloom, N. and J. Van Reenen (2011), "Human Resource Management and Productivity", in Ashenfelter, O.C. and D. Card (eds). Handbook of Labour Economics, Vol. 4, pp. 1697-1767.

Bloom, N., C. Genakos, R. Sadun and J. Van Reenen (2012), "Management Practices Across Firms and Countries", NBER Working Papers, No 17850.

Bloom, N., R. Sadun, and J. Van Reenen (2013), "Management as a Technology", LSE mimeo, http://cep.lse.ac.uk/textonly/_new/staff/vanreenen/pdf/mat_2013dec1.pdf.

Bloom, N., R. Lemos, R. Sadun, D. Scur, J. Van Reenen (2014), “The New Empirical Economics of Management", NBER Working Papers, No. 20102.

Böheim, R., I. Magda and M. Zweimuller (2008), "Skill Mismatch in Europe", Study and Conference on European Labour Market Analysis Using Firm-Level and Linked Employer-Employee Data, European Commission.

Braconier, H., G. Nicoletti and B. Westmore (2014), "Policy Challenges for the Next 50 Years", OECD Economics Department Policy Papers, No. 9. 
Brunello, G. et al. (2007) (eds), Education and Training in Europe, Oxford University Press.

Büchel, F. (2002), "The Effects of Overeducation on Productivity in Germany-the Firms' Viewpoint", Economics of Education Review, Vol. 21, pp. 263-275.

Büchel, F. and M. van Ham (2003), "Over-education, Regional Labour Markets and Spatial Flexibility", Journal of Urban Economics, Vol. 53, pp. 482-493.

Caldera Sánchez, A. and. D. Andrews (2011), "To Move or not to Move: What Drives Residential Mobility Rates in the OECD? ", OECD Economics Department Working Papers, No. 846.

Caldera Sánchez, A. and Å, Johansson (2011) "The Price Responsiveness of Housing Supply in OECD Countries", OECD Economics Department Working Papers, No. 837.

Capelli, P. "Skill Gaps, Skill Shortages and Skill Mismatches: Evidence for the US", NBER Working Papers, No. 20382.

CEDEFOP (2012), "Skill Mismatch: The Role of the Enterprise", Cedefop Research Papers, No. 21.

CEDEFOP (2010), The Skill Matching Challenge: Analysing Skill Mismatch and Policy Implications, Publications Office of the European Union.

Chiswick, B. and P. Miller (2009), "The International Transferability of Immigrants' Human CapitalSkills", Economics of Education Review, Vol. 28 (2), pp. 162-169.

Connolly, S. and M. Gregory (2009), "The Part-time Pay Penalty: Earnings Trajectories of British Women", Oxford Economic Papers, Vol. 61.

Davis, S. and J. Haltiwanger (2014), "Labor Market Fluidity and Economic Performance”, NBER Working Papers, No. 20479.

Desjardins, R. and K. Rubenson (2011), "An Analysis of Skill Mismatch Using Direct Measures of Skills", OECD Education Working Papers, No. 63.

Di Pietro, G. (2002), “Technological Change, Labour Markets and 'Low Skill, Low-technology Traps"”, Technological Forecasting and Social Change, Vol. 69, pp. 885-895.

Eurofound (2008), Working Conditions of an Ageing Workforce, Luxembourg: Office for Official Publications of the European Communities.

European Commission (2013), "The Skill Mismatch Challenge in Europe", EU Commission Staff Working Papers, No. 9.

Hanushek E., G. Schwerdt, S. Wiederhold and L. Woessmann (2013), "Returns to Skills around the World: Evidence from PIAAC", NBER Working Papers, No. 19762.

Hartog, J. (2000), “Overeducation and Earnings: Where are We, Where We Should Go?”, Economics of Education Review, Vol. 19, pp. 131-147.

Hartog, J. and H. Oosterbeek (1988), "Education, Allocation and Earnings in the Netherlands: Overschooling?", Economics of Education Review, Vol. 7, pp. 185-194.

Heckman, J. and P. Carneiro (2003), "Human Capital Policy", NBER Working Papers, No. 9495.

Henley, A. (1998), "Residential Mobility, Housing Equity and the Labour Market", Economic Journal, Vol. 108, pp. 414-427.

Hensen M., R. de Vries and F. Cörvers (2009), "The Role of Geographic Mobility in Reducing EducationJob Mismatches in the Netherlands", Papers in Regional Science, Vol. 88(3), pp. 667-682.

Hersch, J. (1991), "Education Match and Job Match", Review of Economics and Statistics, Vol. 73, pp. 140-144. 


\section{ECO/WKP(2015)28}

Hopenhayn, H. and R. Rogerson (1993), "Job Turnover and Policy Evaluation: A General Equilibrium Analysis", Journal of Political Economy, Vol. 101(5), pp. 915-38.

Janiak, A. and E. Wasmer (2008), "Mobility in Europe-Why is it Low, the Bottlenecks and the Policy Solutions", European Economy, Economic and Financial Affairs Directorate General, European Commission.

Kler, P. (2006), "Overeducation among Tertiary Educated Immigrants to Australia: A Longitudinal Study", Labour Economics Research Group, University of Queensland Discussion Papers, No. 9.

Koske, I., I.Wanner, R. Bitetti and O. Barbiero (2015), "The 2013 Update of the OECD Product Market Regulation Indicators: Policy Insights for OECD and non-OECD countries", OECD Economics Department Working Papers, forthcoming.

Lazear, E.P. and P. Oyer (2009), "Personnel Economics", in Gibbons, R. and Roberts, D.J. (eds). Handbook of Organisational Economics, Princeton University Press.

Lind, H (2001), "Rent Regulation: A Conceptual and Comparative Analysis", International Journal of Housing Policy, Vol. 1 (1), pp. 41-57.

Marsden, D., C. Lucifora, J. Oliver-Alonso and Y. Guillotin (2002), The Economic Costs of the Skills Gap in the EU, Istituto per la Ricerca Sociale, Milan, Italy.

Mavromaras, K. and S. McGuinness (2012), "Overskilling Dynamics and Education Pathways", Economics of Education Review, Vol. 31(5), pp. 619-628.

Mavromaras, K., S. Mahuteau, P. Sloane and Z. Wei (2013), "The Effect of Overskilling Dynamics on Wages", Education Economics, Vol. 21(3), pp. 281-303.

McGuinness, S. (2006), "Overeducation in the Labour Market", Journal of Economic Surveys, Vol. 20, pp. $387-418$.

Mcguinness, S. and L. Ortiz (2014), "Who Should We Ask? Employer and Employee Perceptions of Skill Gaps within Firms", ESRI Working Papers, No. 482.

Messinis, G., and N. Olekalns (2007), "Skill Mismatch and Training in Australia: Some Implications for Policy", Australian Economic Review, Vol. 40, pp. 300-306.

Neira, J. (2014), "Recovery Rate, Misallocation of Talent and Cross-Country Differences", University of Exeter, mimeo.

Nieto, S., A. Matano and R. Ramos (2014), "Skill Mismatches in the EU: Immigrants vs. Natives", Research Institute of Applied Economics Working Papers, No. 18.

OECD (2004), Employment Outlook, 2004, OECD, Paris.

OECD (2013), Skills Outlook 2013, OECD, Paris.

OECD (2014a), Employment Outlook 2014, OECD, Paris.

OECD (2014b), Migration Outlook 2014, OECD, Paris.

Oswald, A.J. (1999), "The Housing Market and Europe's Unemployment: A Non-Technical Paper", Mimeo, University of Warwick.

Pica, G. and J. Rodriguez Mora (2005), "Who is Afraid of a Globalised World? FDI and the Allocation of Talent", CSEF Working Papers, No. 184.

Prokic-Beuer, T. and P. McManus (2013), "Immigrant Qualification Mismatch in 13 Developed Countries, Apparent or Real", mimeo.

Quintini, G. (2011), "Right for the Job: Over-qualified or Under-skilled?", OECD Social, Employment and Migration Working Papers, No. 120. 
Robst, J. (1995), “Career Mobility, Job Match, and Overeducation”, Eastern Economic Journal, Vol. 2, pp. $539-550$

Sicherman, N. (1991), "Overeducation in the Labor Market”, Journal of Labour Economics, Vol. 9, pp. $101-122$

Sims, D. (2007), "Out of Control: What Can We Learn from the End of Massachusetts Rent Control?", Journal of Urban Economics, Vol. 1.

Sloane, P. J., H. Battu and P. T. Seaman (1999), "Overeducation, Undereducation and the British Labour Market”, Applied Economics, 31(11), pp. 1437-1453.

Sparreboom, T. (2014), “Gender Equality, Part-time Work and Segregation”, International Labour Review, Vol. 153, No. 2.

Van der Vlist, A.J., C. Gorter, P. Nijkamp and P. Rietveld (2002) "Residential Mobility and Local Housing Market Differences", Tinbergen Institute Discussion Papers, No. 3.

Van Ommeren, J. and M. Van Leuvensteijn (2005), "New Evidence of the Effect of Transaction Costs on Residential Mobility", Journal of Regional Science, Vol. 45.

Van Smoorenburg, M. and R. van der Velden (2000), "The Training of School Leavers, Complementarity or Substitution?", Economics of Education Review, Vol. 19, pp. 207-217.

Verhaest, D. and E. Omey (2009), "The Determinants of Over-education: Different Measures, Different Outcomes?", University of Gent, Department of Economics Working Paper, No. 592.

Weststar, J. (2009), "Worker Control as a Facilitator in the Match between Education and Jobs", British Journal of Industrial Relations, Vol. 47, No. 4, pp. 723-740.

World Economic Forum (2014), Matching Skills and Needs: Building Social Partnerships for Better Skills and Better Jobs, January. 


\section{APPENDIX A. SELECTED POLICY INDICATORS}

\section{Figure A1. Cost of closing a business}

The average cost of bankruptcy proceedings as a percentage of the estate's value $\square 2014 \bullet 2004$

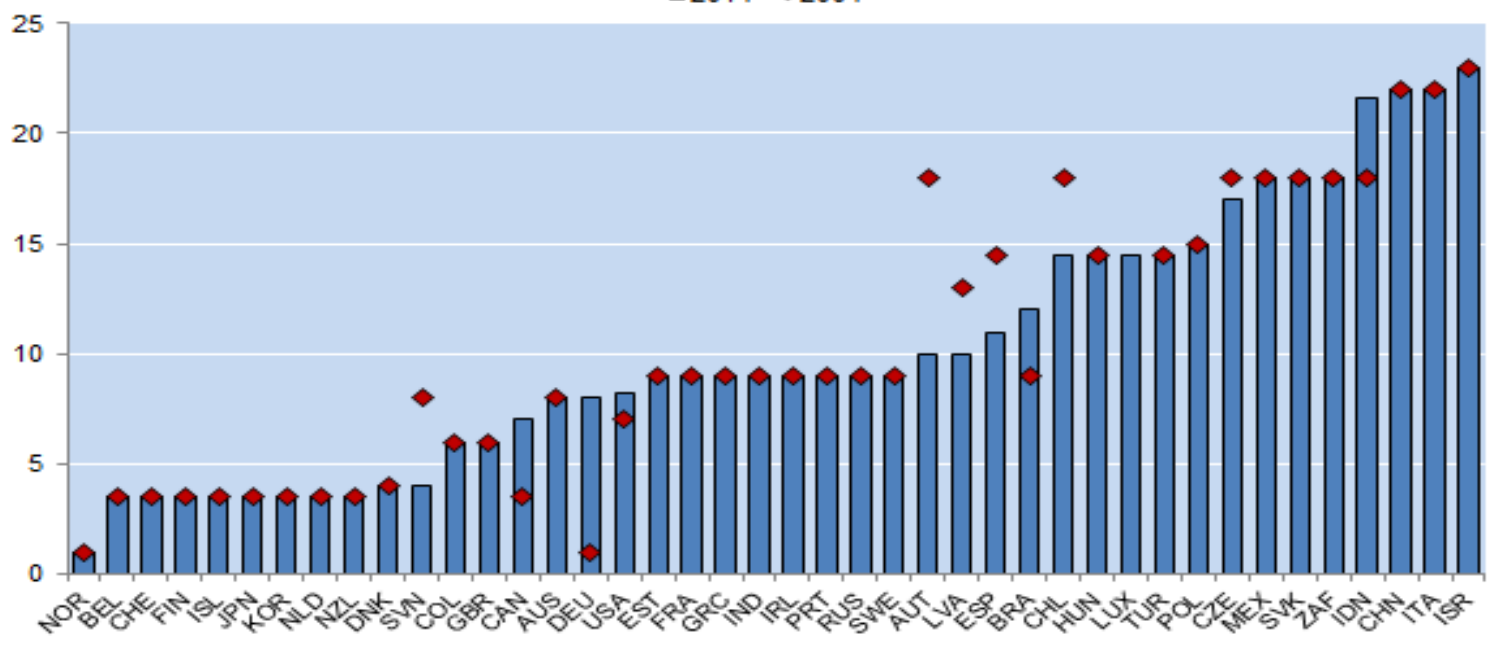

Notes: The cost is calculated on the basis of questionnaire responses and includes court fees and government levies; fees of insolvency administrators, auctioneers, assessors and lawyers; and all other fees and costs. Data refer to 2005 for Iceland. 2004 data refer to São Paulo for Brazil, Shanghai for China, Mumbai for India, Jakarta for Indonesia, Mexico City for Mexico, New York for the United States, Tokyo for Japan and Moscow City for Russia.

Source: World Bank Doing Business Database.

Figure A2. Transaction costs on buyer by type, 2009

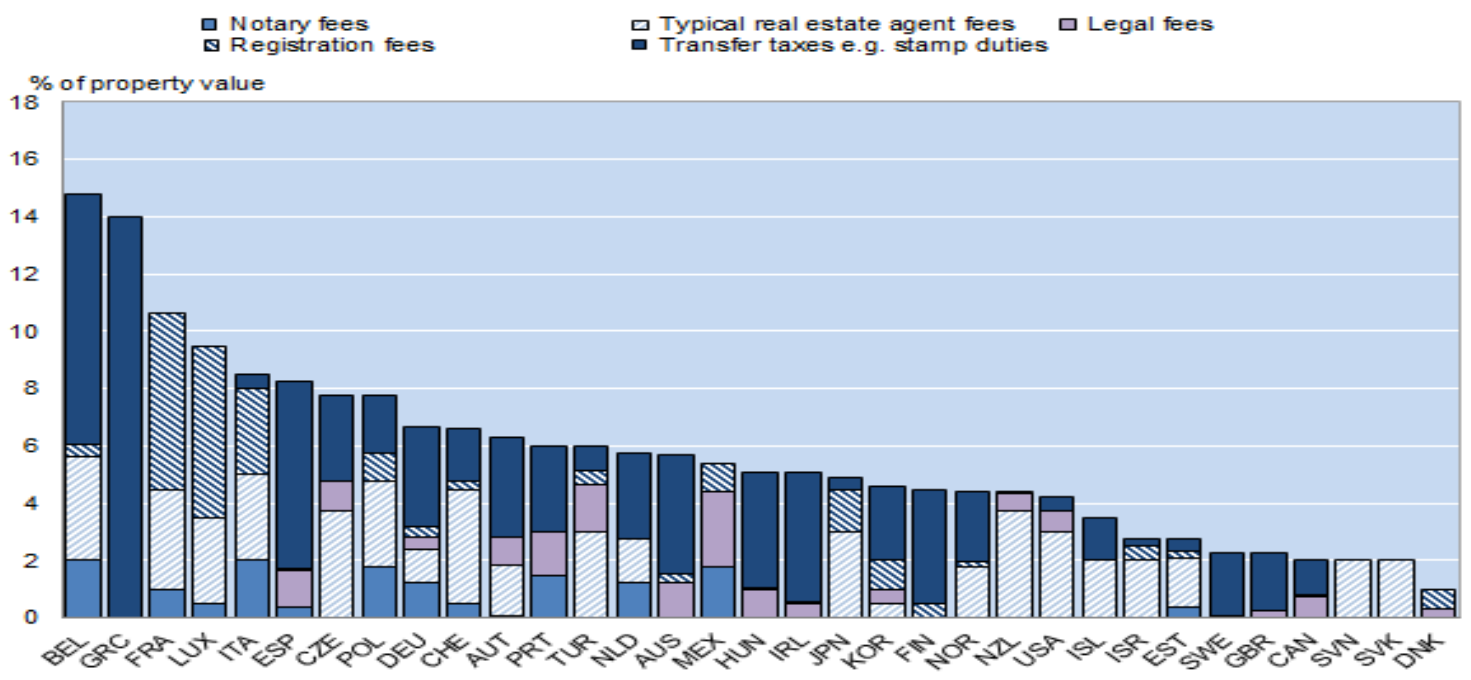

Notes: Transaction costs refer to average costs.

Source: Andrews et al. (2011). 
Figure A3. Pro-tenant regulations, 2009

A: Rent control in the private rental market, 2009

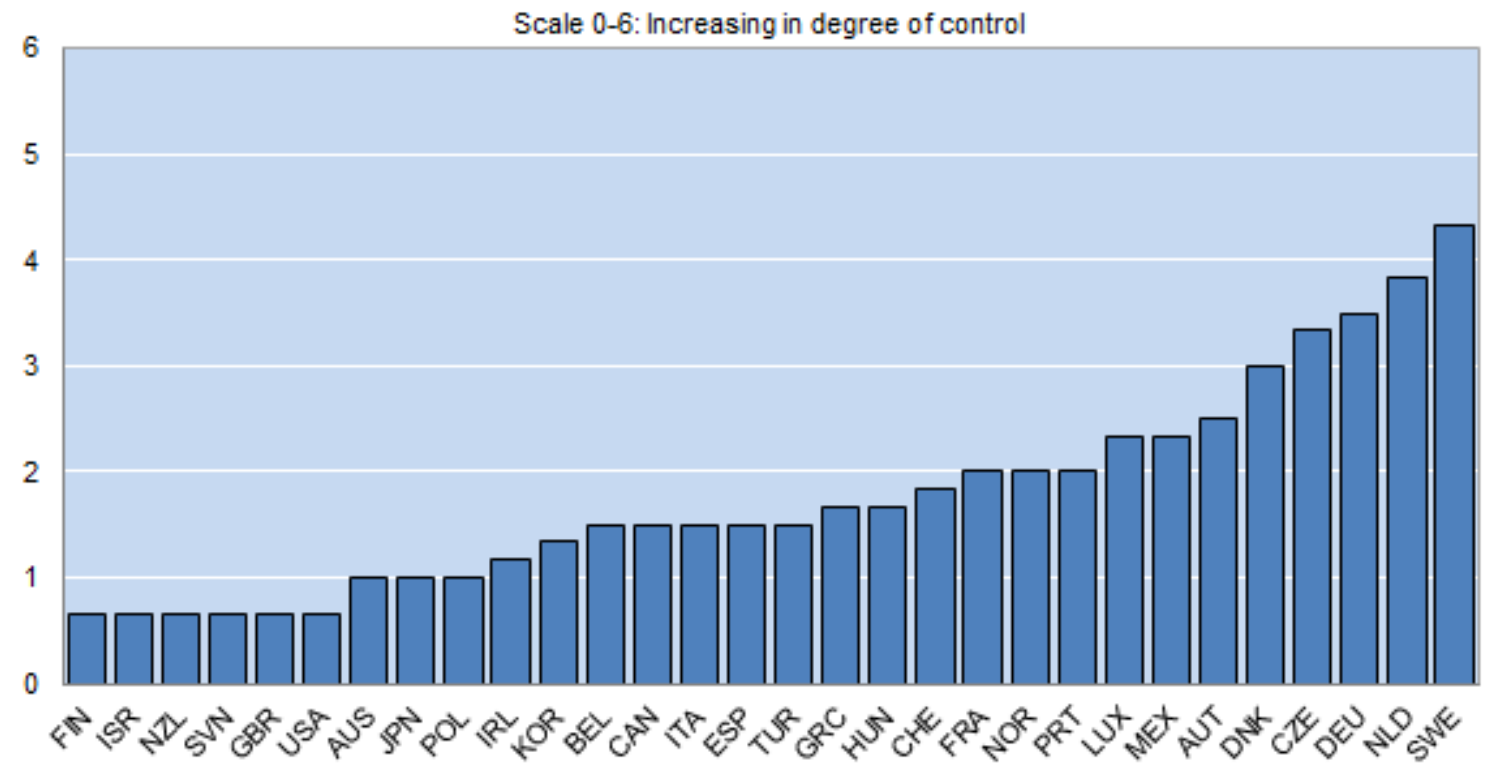

B: Tenant-landlord regulations in private rental market, 2009

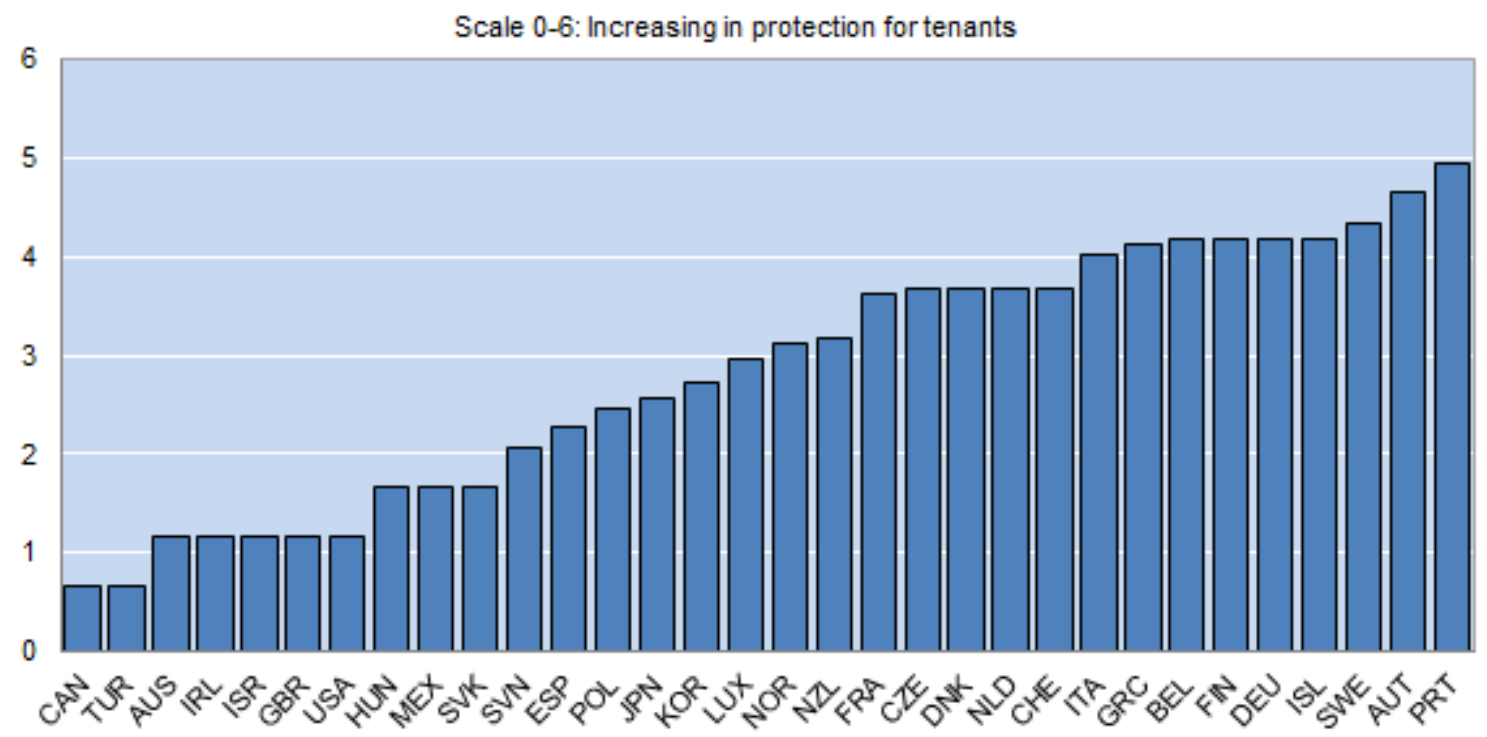

Notes: Panel A: This indicator is a composite indicator of the extent of controls of rents, how increases in rents are determined and the permitted cost pass-through onto rents in each country. Panel B: The indicator measures the extent of tenant-landlord regulation within a tenancy. It includes the ease of evicting a tenant, degree of tenure security and deposit requirements.

Source: Andrews et al. (2011). 
Figure A4. Number of days to obtain a building permit, 2014

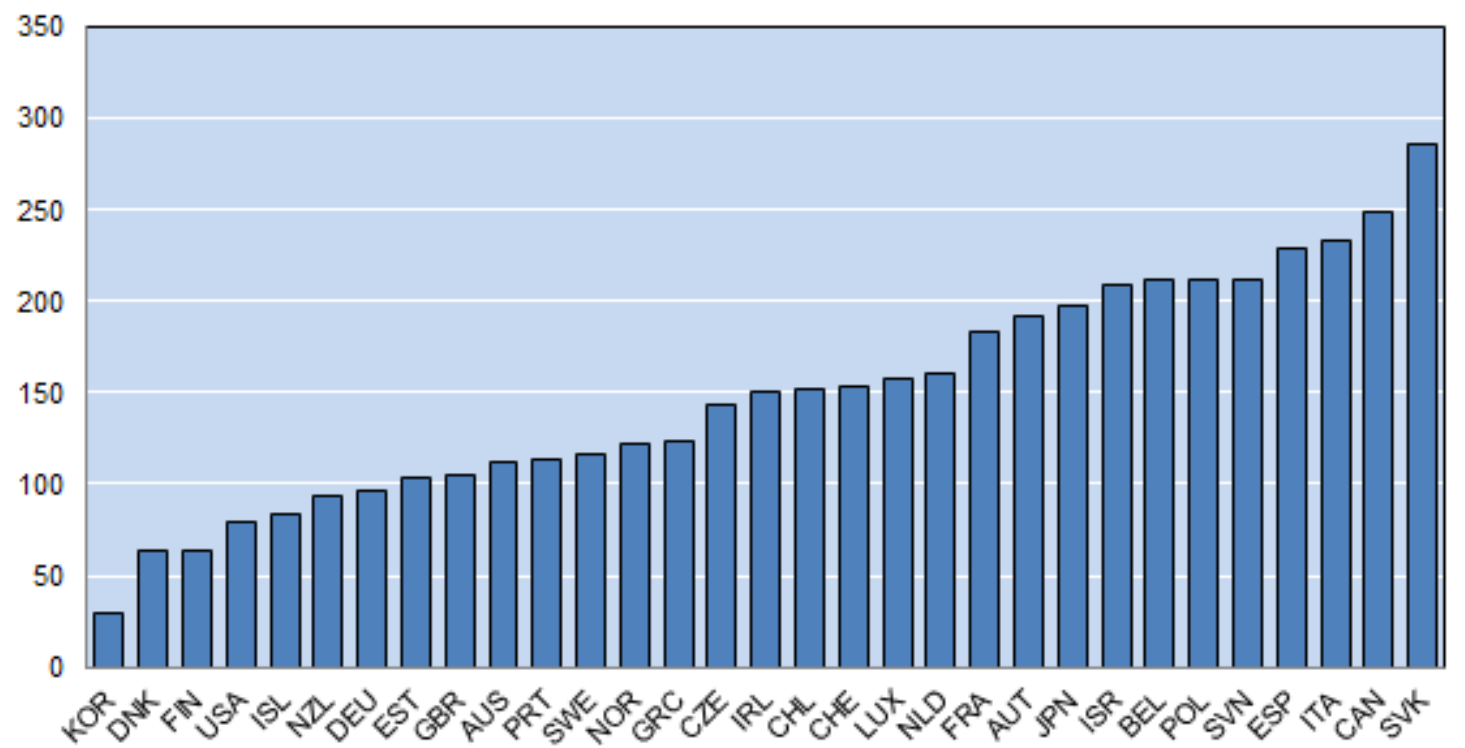

Notes: The number of days to obtain a building permit measured as the median duration that local experts indicate is necessary to complete a procedure in practice.

Source: World Bank Doing Business (2014).

Table A1. Data sources for policy-related variables

\begin{tabular}{|c|c|}
\hline Product market regulation & Overall PMR index from OECD, Product Market Regulation Database, 2008 \\
\hline EPL (permanent) & $\begin{array}{l}\text { OECD, Employment Protection Legislation Database, indicator for the protection } \\
\text { of permanent workers against individual and collective dismissals, } 2013\end{array}$ \\
\hline EPL (temporary) & $\begin{array}{l}\text { OECD, Employment Protection Legislation Database, indicator for the regulation } \\
\text { on temporary forms of employment, } 2013\end{array}$ \\
\hline Cost of closing a business & World Bank, Doing Business Database, 2014 \\
\hline Transaction Costs & Andrews et al. (2011), data refer to 2009 \\
\hline Rent control & Andrews et al. (2011), data refer to 2009 \\
\hline Tenant-landlord regulations & Andrews et al. (2011), data refer to 2009 \\
\hline Cost of obtaining a building permits & World Bank, Doing Business Database, 2014 \\
\hline Responsiveness of housing supply & Andrews et al. (2011), data refer to 2009 \\
\hline Participation in lifelong learning & Calculations based on PIAAC, 2011-12; Eurostat, 2012 \\
\hline $\begin{array}{l}\text { Coverage rate of collective bargaining } \\
\text { agreements }\end{array}$ & $\begin{array}{l}\text { Going For Growth (2015), based on Database on Institutional Characteristics of } \\
\text { Trade Unions, Wage-Setting, State Intervention and Social Pacts, 1960-2011 }\end{array}$ \\
\hline Managerial quality & Calculations based on PIAAC, 2011-12 \\
\hline
\end{tabular}

Notes: Transaction costs include a number of fees such as transfer taxes (e.g. stamp duties), registration fees incurred when registering the property in the land registry, notarial or other legal fees and typical real estate agency fees. Rent control is a composite indicator of the extent of controls of rents, how increases in rents are determined and the permitted cost pass-through onto rents in each country. The tenant-landlord regulation indicator measures the ease of evicting a tenant, degree of tenure security and deposit requirements. The responsiveness of the housing supply is based on the estimates of the long-run elasticity of new housing supply, where new supply is measured by residential investment. 
ECO/WKP(2015)28

APPENDIX B. COUNTRY-BY-COUNTRY ESTIMATIONS

Table B1. Individual characteristics and skill mismatch: country-by-country regressions

\begin{tabular}{|c|c|c|c|c|c|c|c|c|c|c|c|}
\hline & (1) & $(2)$ & (3) & (4) & (5) & (6) & $(7)$ & $(8)$ & (9) & $(10)$ & $(11)$ \\
\hline & Australia & Austria & Belgium & Canada & $\begin{array}{l}\text { Czech } \\
\text { Republic }\end{array}$ & Denmark & Estonia & Finland & France & Germany & Ireland \\
\hline \multicolumn{12}{|c|}{ Dependent variable: 1 if the individual is mismatched, 0 otherwise } \\
\hline \multirow[t]{2}{*}{ Single } & 0.011 & $-0.070^{* *}$ & $0.055^{\text {*** }}$ & -0.002 & 0.030 & 0.007 & -0.002 & 0.024 & -0.007 & 0.025 & -0.022 \\
\hline & $(0.025)$ & $(0.028)$ & $(0.021)$ & $(0.017)$ & $(0.037)$ & $(0.023)$ & $(0.016)$ & $(0.031)$ & $(0.016)$ & $(0.029)$ & $(0.027)$ \\
\hline \multirow[t]{2}{*}{ Female } & $-0.056^{* *}$ & $-0.069^{* * z}$ & -0.021 & $-0.036^{2 \pm z}$ & $-0.080^{* \pm *}$ & $-0.035^{* *}$ & -0.015 & -0.012 & $-0.041^{\text {tat }}$ & $-0.058^{* \pm *}$ & -0.031 \\
\hline & $(0.022)$ & $(0.021)$ & $(0.016)$ & $(0.014)$ & $(0.028)$ & $(0.016)$ & $(0.015)$ & $(0.016)$ & $(0.014)$ & $(0.018)$ & $(0.022)$ \\
\hline \multirow[t]{2}{*}{ Immigrant } & 0.022 & -0.032 & $0.093^{* *}$ & 0.022 & 0.137 & $0.115^{\text {*z*}}$ & 0.017 & 0.055 & $0.037^{*}$ & -0.023 & 0.026 \\
\hline & $(0.021)$ & $(0.029)$ & $(0.025)$ & $(0.014)$ & $(0.093)$ & $(0.016)$ & $(0.022)$ & $(0.040)$ & $(0.020)$ & $(0.029)$ & $(0.024)$ \\
\hline \multirow[t]{2}{*}{ Age 25-34 } & -0.002 & -0.014 & 0.037 & $-0.041^{*}$ & 0.031 & 0.031 & -0.025 & $0.084^{* *}$ & 0.026 & $-0.084^{* *}$ & $-0.113^{* * *}$ \\
\hline & $(0.036)$ & $(0.040)$ & $(0.033)$ & $(0.022)$ & $(0.057)$ & $(0.031)$ & $(0.025)$ & $(0.037)$ & $(0.027)$ & $(0.038)$ & $(0.035)$ \\
\hline \multirow[t]{2}{*}{ Age $35-44$} & $-0.074^{* *}$ & -0.030 & 0.029 & $-0.059^{* * *}$ & -0.034 & 0.014 & $-0.057^{\star *}$ & -0.010 & -0.026 & $-0.127^{\text {tat}}$ & $-0.092^{\text {t* }}$ \\
\hline & $(0.035)$ & $(0.037)$ & $(0.031)$ & $(0.020)$ & $(0.056)$ & $(0.030)$ & $(0.025)$ & $(0.039)$ & $(0.028)$ & $(0.034)$ & $(0.036)$ \\
\hline \multirow[t]{2}{*}{ Age $45-54$} & $-0.081^{* *}$ & $-0.063^{*}$ & 0.017 & $-0.044^{ \pm z}$ & $-0.116^{* *}$ & -0.040 & $-0.052^{* *}$ & -0.025 & -0.020 & $-0.210^{\mathrm{ztz}}$ & $-0.124^{\text {tz*}}$ \\
\hline & $(0.038)$ & $(0.038)$ & $(0.034)$ & $(0.022)$ & $(0.051)$ & $(0.034)$ & $(0.026)$ & $(0.043)$ & $(0.029)$ & $(0.038)$ & $(0.041)$ \\
\hline \multirow[t]{2}{*}{ Age $55-65$} & $-0.081^{* *}$ & $-0.184^{\text {t*k }}$ & 0.033 & $-0.065^{* * *}$ & $-0.136^{* *}$ & -0.040 & $-0.065^{* *}$ & 0.012 & -0.038 & $-0.188^{* * *}$ & -0.075 \\
\hline & $(0.038)$ & $(0.054)$ & $(0.037)$ & $(0.023)$ & $(0.062)$ & $(0.034)$ & $(0.030)$ & $(0.038)$ & $(0.035)$ & $(0.040)$ & $(0.049)$ \\
\hline \multirow[t]{2}{*}{ Upper secondary } & $0.063^{* 2}$ & $-0.075^{* * 2}$ & $-0.059^{* 2}$ & 0.021 & $0.203^{\text {t*k*}}$ & -0.008 & -0.001 & -0.008 & -0.030 & -0.010 & $0.106^{* 2 * 2}$ \\
\hline & $(0.028)$ & $(0.027)$ & $(0.025)$ & $(0.023)$ & $(0.062)$ & $(0.022)$ & $(0.025)$ & $(0.035)$ & $(0.019)$ & $(0.037)$ & $(0.039)$ \\
\hline \multirow{2}{*}{$\begin{array}{l}\text { Post-secondary, non- } \\
\text { tertiary }\end{array}$} & 0.042 & $-0.060^{*}$ & -0.067 & 0.022 & $0.328^{\text {*t*k}}$ & -0.039 & 0.037 & -0.015 & 0.000 & $0.180^{* * *}$ & $0.119^{* * *}$ \\
\hline & $(0.047)$ & $(0.032)$ & $(0.049)$ & $(0.027)$ & $(0.108)$ & $(0.067)$ & $(0.038)$ & $(0.052)$ & $(0.000)$ & $(0.047)$ & $(0.043)$ \\
\hline \multirow[t]{2}{*}{ Tertiary } & 0.009 & $-0.062^{* *}$ & -0.012 & $0.051^{* *}$ & $0.310^{\text {*z* }}$ & 0.035 & 0.020 & 0.058 & -0.021 & $0.077^{*}$ & $0.135^{* * *}$ \\
\hline & $(0.028)$ & $(0.031)$ & $(0.025)$ & $(0.023)$ & $(0.065)$ & $(0.022)$ & $(0.025)$ & $(0.036)$ & $(0.021)$ & $(0.042)$ & $(0.037)$ \\
\hline \multirow[t]{2}{*}{ Firm size: $11-50$} & -0.007 & 0.022 & 0.004 & 0.006 & 0.050 & 0.021 & -0.010 & 0.006 & -0.012 & 0.009 & $-0.047^{2}$ \\
\hline & $(0.029)$ & $(0.026)$ & $(0.022)$ & $(0.017)$ & $(0.037)$ & $(0.021)$ & $(0.017)$ & $(0.024)$ & $(0.018)$ & $(0.027)$ & $(0.026)$ \\
\hline \multirow[t]{2}{*}{ Firm size: $51-250$} & 0.041 & $0.060^{\text {*z }}$ & $-0.049^{* 2}$ & 0.010 & 0.019 & -0.003 & 0.007 & $0.066^{* * 2}$ & -0.030 & $0.076^{* * *}$ & 0.009 \\
\hline & $(0.028)$ & $(0.027)$ & $(0.024)$ & $(0.016)$ & $(0.046)$ & $(0.024)$ & $(0.020)$ & $(0.024)$ & $(0.021)$ & $(0.028)$ & $(0.029)$ \\
\hline \multirow[t]{2}{*}{ Firm size: $251-999$} & -0.039 & $0.088^{* *}$ & -0.030 & $0.040^{* z}$ & $0.115^{* *}$ & 0.000 & 0.020 & 0.033 & $-0.044^{* *}$ & -0.006 & -0.016 \\
\hline & $(0.039)$ & $(0.031)$ & $(0.028)$ & $(0.019)$ & $(0.048)$ & $(0.031)$ & $(0.025)$ & $(0.029)$ & $(0.022)$ & $(0.030)$ & $(0.029)$ \\
\hline \multirow[t]{2}{*}{ Firm size: $>1000$} & 0.005 & 0.013 & 0.012 & 0.025 & -0.120 & 0.042 & 0.029 & -0.026 & -0.015 & $0.105^{\text {tat }}$ & 0.020 \\
\hline & $(0.040)$ & $(0.040)$ & $(0.031)$ & $(0.024)$ & $(0.074)$ & $(0.031)$ & $(0.046)$ & $(0.045)$ & $(0.024)$ & $(0.030)$ & $(0.038)$ \\
\hline \multirow[t]{2}{*}{ Fixed contract } & 0.023 & 0.032 & 0.017 & 0.007 & 0.013 & -0.004 & 0.011 & -0.029 & -0.031 & $-0.057^{*}$ & $0.045^{*}$ \\
\hline & $(0.033)$ & $(0.030)$ & $(0.031)$ & $(0.018)$ & $(0.036)$ & $(0.023)$ & $(0.022)$ & $(0.027)$ & $(0.021)$ & $(0.032)$ & $(0.027)$ \\
\hline \multirow{2}{*}{$\begin{array}{l}\text { Temp agency/No } \\
\text { contract/Apprenticeship }\end{array}$} & 0.015 & $-0.113^{* *}$ & $0.070^{*}$ & 0.022 & 0.017 & $-0.078^{* *}$ & 0.034 & $0.089^{*}$ & 0.023 & -0.047 & $-0.060^{* *}$ \\
\hline & $(0.027)$ & $(0.045)$ & $(0.041)$ & $(0.016)$ & $(0.102)$ & $(0.032)$ & $(0.037)$ & $(0.050)$ & $(0.026)$ & $(0.035)$ & $(0.030)$ \\
\hline \multirow[t]{2}{*}{ Part-time worker } & $0.057^{* 2}$ & $0.098^{* 2 * *}$ & 0.017 & $0.058^{* 2 * z}$ & 0.019 & $0.063^{* \pm}$ & $0.044^{*}$ & 0.028 & $0.042^{* *}$ & $0.108^{* \pm *}$ & 0.042 \\
\hline & $(0.022)$ & $(0.024)$ & $(0.024)$ & $(0.017)$ & $(0.064)$ & $(0.025)$ & $(0.024)$ & $(0.030)$ & $(0.016)$ & $(0.020)$ & $(0.026)$ \\
\hline \multirow[t]{2}{*}{ Public sector/NGO } & -0.008 & $-0.089^{* * *}$ & -0.025 & 0.019 & -0.035 & -0.001 & $0.025^{*}$ & -0.011 & $0.050^{* * *}$ & 0.004 & $-0.049^{* *}$ \\
\hline & $(0.025)$ & $(0.022)$ & $(0.016)$ & $(0.014)$ & $(0.036)$ & $(0.015)$ & $(0.014)$ & $(0.019)$ & $(0.017)$ & $(0.020)$ & $(0.023)$ \\
\hline Number of observations & 3262 & 2539 & 2464 & 13145 & 2179 & 3722 & 3648 & 2498 & 3025 & 2728 & 2316 \\
\hline
\end{tabular}


Table B1. Individual characteristics and skill mismatch: country-by-country regressions (cont'd)

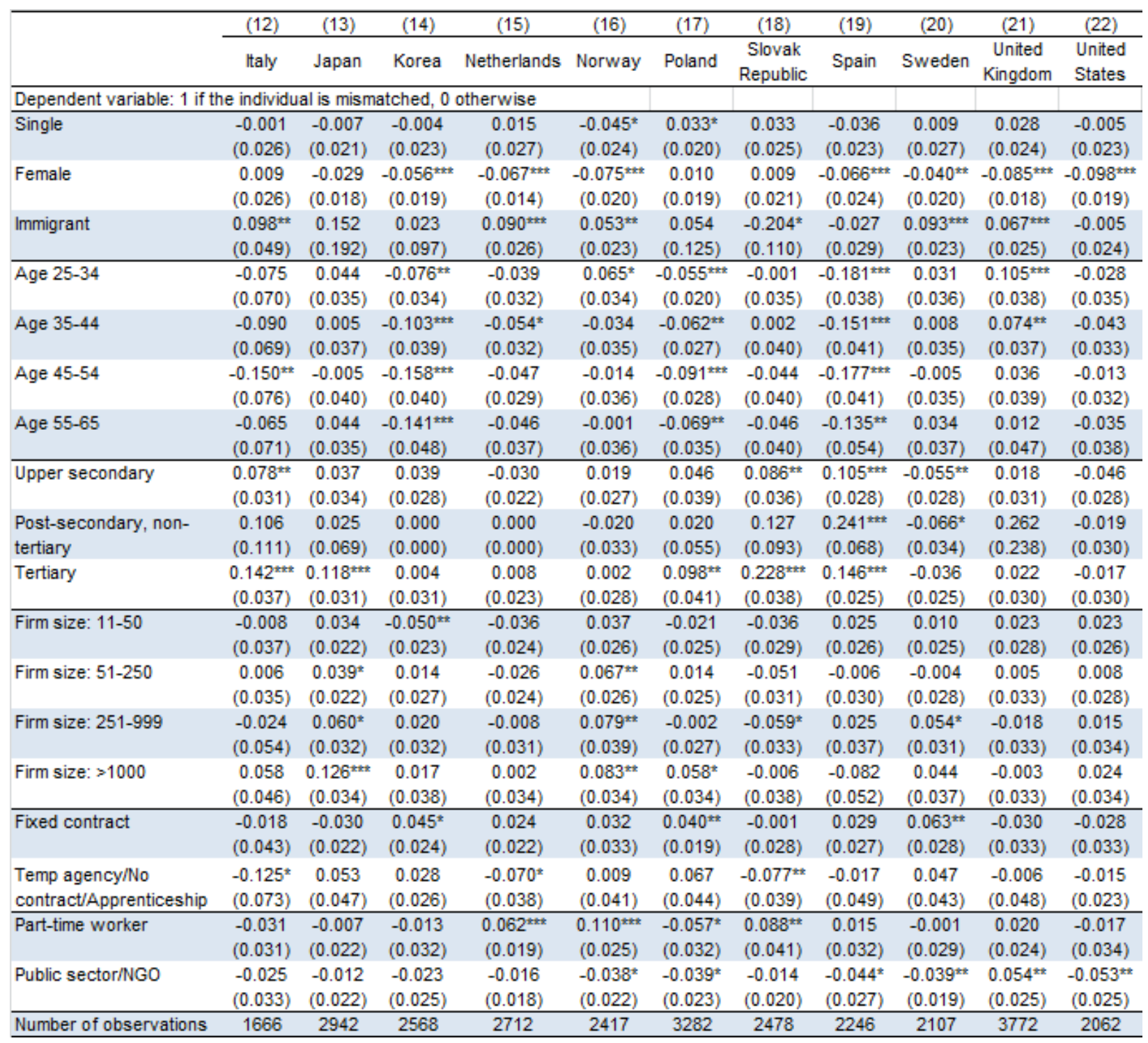

Notes: Estimates from logit regressions. Values are marginal effects. The coefficients correspond to the impact of a change in the explanatory variable on the probability of mismatch at the mean of the independent variables. Regressions include as controls age, marital and migrant status, gender, level of education, firm size, contract type, a dummy for working full-time and working in the private sector. Robust standard errors in parentheses. ${ }^{* * *}$ denotes statistical significance at the $1 \%$ level, ${ }^{* *}$ significance at the $5 \%$ level, * significance at the $10 \%$ level.

Source: OECD calculations based on the Survey of Adult Skills (2012). 
ECO/WKP(2015)28

Table B2. Individual characteristics and over-skilling: country-by-country regressions

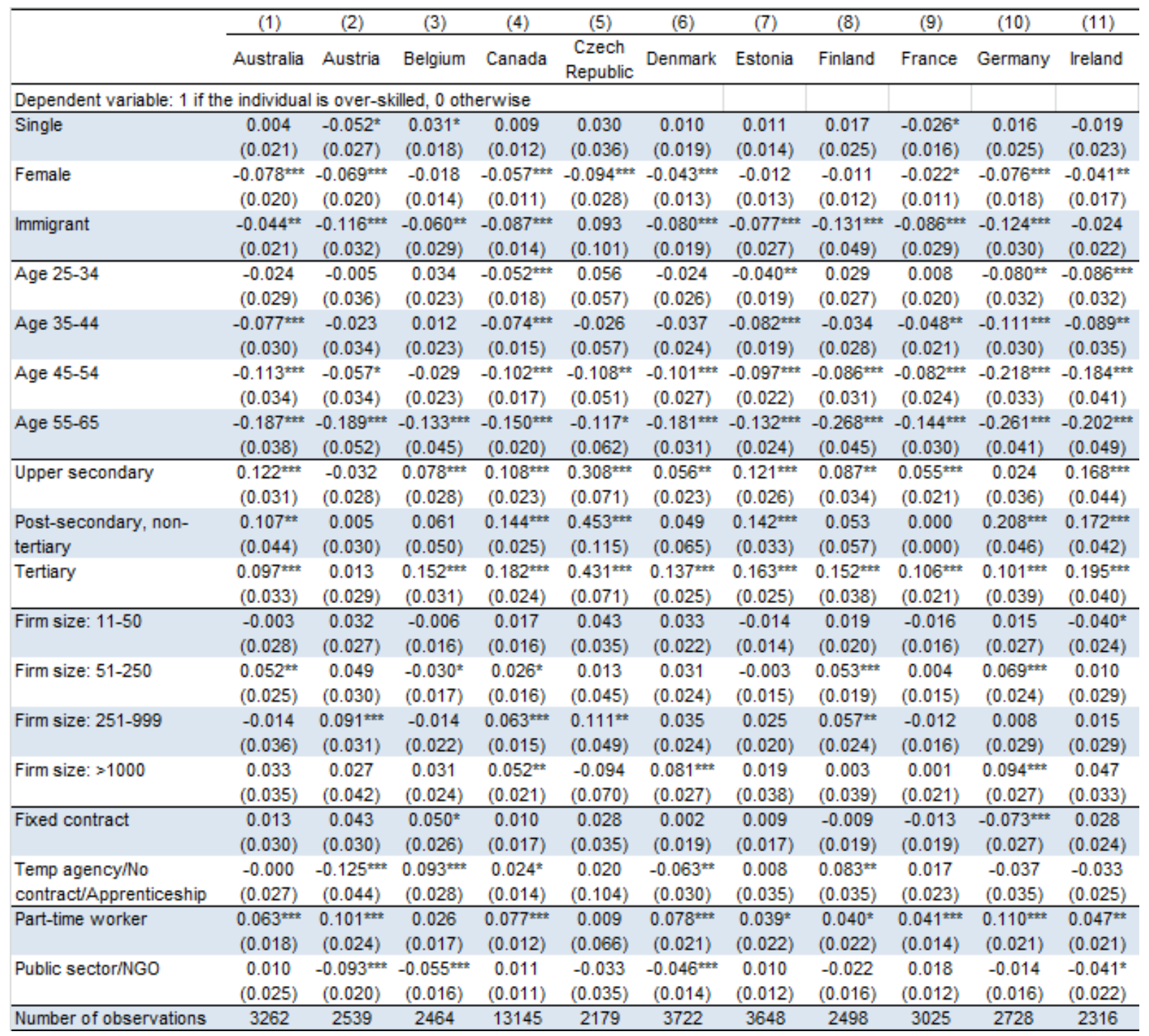


ECO/WKP(2015)28

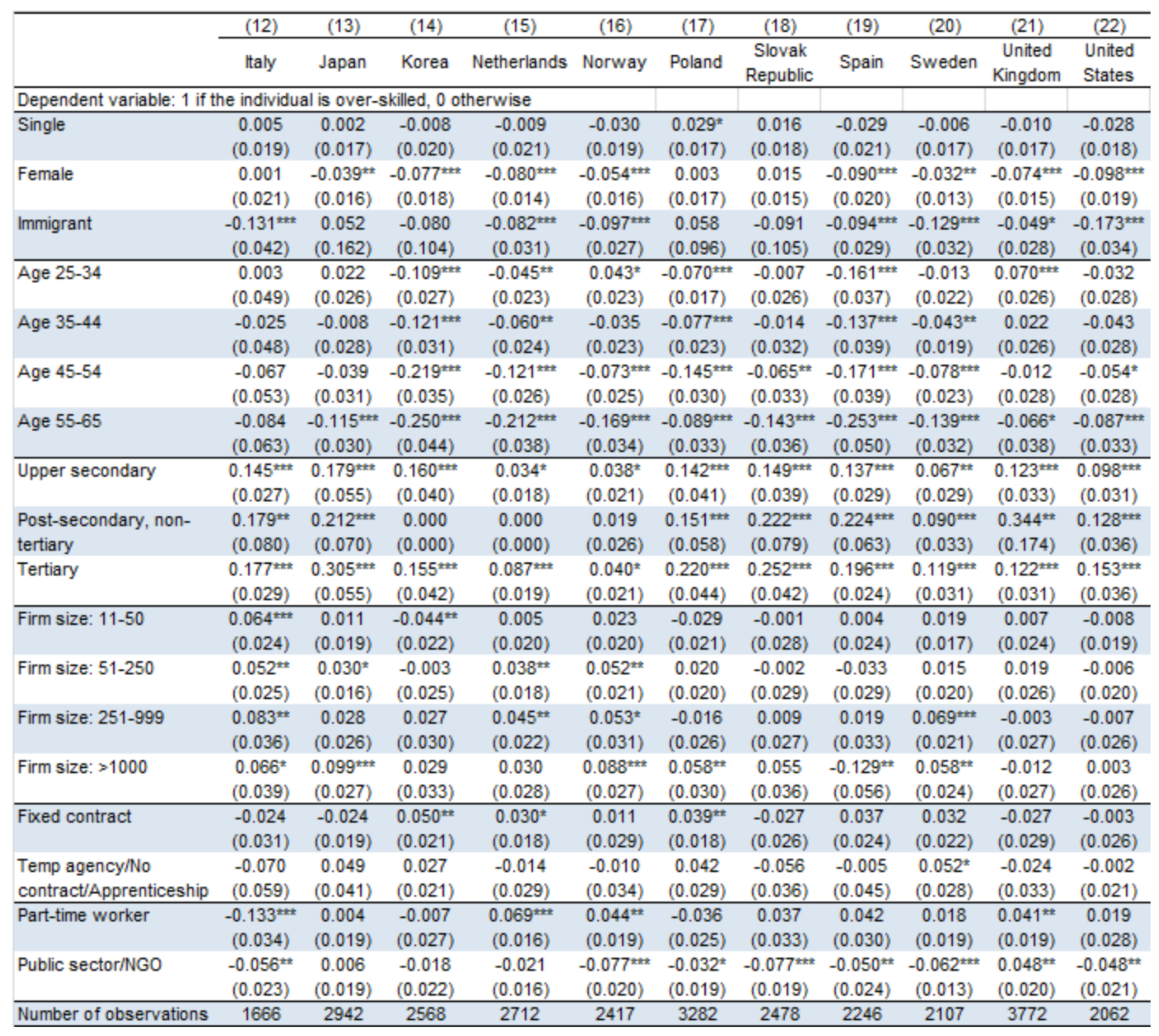

Notes: Estimates from logit regressions. Values are marginal effects. The coefficients correspond to the impact of a change in the explanatory variable on the probability of mismatch at the mean of the independent variables. Regressions include as controls age, marital and migrant status, gender, level of education, firm size, contract type, a dummy for working full-time and working in the private sector. Robust standard errors in parentheses. ${ }^{* *}$ denotes statistical significance at the $1 \%$ level, ${ }^{* *}$ significance at the $5 \%$ level, ${ }^{*}$ significance at the $10 \%$ level.

Source: OECD calculations based on the Survey of Adult Skills (2012). 
ECO/WKP(2015)28

Table B3. Individual characteristics and under-skilling: country-by-country regressions

\begin{tabular}{|c|c|c|c|c|c|c|c|c|c|c|c|}
\hline & (1) & $(2)$ & $(3)$ & (4) & $(5)$ & (6) & $(7)$ & $(8)$ & $(9)$ & $(10)$ & $(11)$ \\
\hline & Australia & Austria & Belgium & Canada & $\begin{array}{c}\text { Czech } \\
\text { Republic }\end{array}$ & Denmark & Estonia & Finland & France & Germany & Ireland \\
\hline \multicolumn{12}{|c|}{ Dependent variable: 1 if the individual is under-skilled, 0 otherwise } \\
\hline \multirow[t]{2}{*}{ Single } & 0.006 & $-0.018^{2}$ & $0.023^{*}$ & -0.012 & 0.001 & 0.003 & -0.015 & 0.014 & $0.023^{* *}$ & 0.007 & -0.006 \\
\hline & $(0.015)$ & $(0.011)$ & $(0.013)$ & $(0.012)$ & $(0.010)$ & $(0.017)$ & $(0.009)$ & $(0.020)$ & $(0.011)$ & $(0.015)$ & $(0.017)$ \\
\hline \multirow[t]{2}{*}{ Female } & $0.019^{*}$ & 0.002 & -0.004 & $0.017^{* *}$ & 0.012 & 0.006 & -0.002 & -0.006 & $-0.023^{* \pm}$ & $0.018^{* *}$ & 0.011 \\
\hline & $(0.010)$ & $(0.008)$ & $(0.010)$ & $(0.008)$ & $(0.009)$ & $(0.007)$ & $(0.010)$ & $(0.012)$ & $(0.009)$ & $(0.008)$ & $(0.014)$ \\
\hline \multirow[t]{2}{*}{ Immigrant } & $0.054^{\text {*z*}}$ & $0.049^{* 2 * *}$ & $0.101^{\text {taz }}$ & $0.075^{\text {t** }}$ & $0.030^{* *}$ & $0.123^{* \pm z}$ & $0.056^{* * *}$ & $0.106^{* * *}$ & $0.067^{* \pm *}$ & $0.060^{\text {*z*}}$ & $0.050^{\text {tz*t}}$ \\
\hline & $(0.011)$ & $(0.010)$ & $(0.013)$ & $(0.009)$ & $(0.014)$ & $(0.008)$ & $(0.011)$ & $(0.022)$ & $(0.011)$ & $(0.013)$ & $(0.014)$ \\
\hline \multirow[t]{2}{*}{ Age $25-34$} & 0.027 & -0.016 & -0.026 & 0.019 & $-0.042^{* z}$ & $0.053^{* *}$ & 0.022 & 0.065 & 0.002 & -0.006 & -0.024 \\
\hline & $(0.022)$ & $(0.014)$ & $(0.024)$ & $(0.017)$ & $(0.018)$ & $(0.025)$ & $(0.019)$ & $(0.043)$ & $(0.023)$ & $(0.021)$ & $(0.034)$ \\
\hline \multirow[t]{2}{*}{ Age $35-44$} & 0.006 & -0.008 & 0.013 & $0.033^{*}$ & -0.008 & $0.053^{* t}$ & $0.041^{\text {*t* }}$ & 0.048 & 0.036 & -0.023 & 0.013 \\
\hline & $(0.021)$ & $(0.014)$ & $(0.022)$ & $(0.018)$ & $(0.015)$ & $(0.026)$ & $(0.018)$ & $(0.043)$ & $(0.022)$ & $(0.022)$ & $(0.030)$ \\
\hline \multirow[t]{2}{*}{ Age $45-54$} & 0.033 & -0.007 & $0.040^{*}$ & $0.064^{\text {tat }}$ & -0.012 & $0.068^{* 2 *}$ & $0.060^{* 2 *}$ & $0.099^{* \pm z}$ & $0.068^{* * *}$ & 0.014 & $0.055^{*}$ \\
\hline & $(0.024)$ & $(0.013)$ & $(0.023)$ & $(0.018)$ & $(0.016)$ & $(0.025)$ & $(0.018)$ & $(0.044)$ & $(0.023)$ & $(0.023)$ & $(0.031)$ \\
\hline \multirow[t]{2}{*}{ Age $55-65$} & $0.059^{* *}$ & -0.005 & $0.080^{* \pm z}$ & $0.068^{* 2 \pm}$ & -0.022 & $0.101^{* \pm *}$ & $0.066^{\mathrm{kz}}$ & $0.163^{* \pm *}$ & $0.075^{* * *}$ & $0.048^{* *}$ & $0.086^{\text {tz*x}}$ \\
\hline & $(0.024)$ & $(0.017)$ & $(0.024)$ & $(0.017)$ & $(0.018)$ & $(0.025)$ & $(0.019)$ & $(0.042)$ & $(0.025)$ & $(0.023)$ & $(0.033)$ \\
\hline \multirow[t]{2}{*}{ Upper secondary } & $-0.034^{* 2}$ & $-0.026^{\text {taz }}$ & $-0.054^{\text {*atz }}$ & $-0.036^{\text {*t*k}}$ & -0.016 & $-0.027^{\text {tz }}$ & $-0.071^{* 2 *}$ & $-0.040^{* 2}$ & $-0.034^{* \pm z}$ & $-0.024^{*}$ & -0.020 \\
\hline & $(0.014)$ & $(0.009)$ & $(0.012)$ & $(0.012)$ & $(0.011)$ & $(0.013)$ & $(0.012)$ & $(0.018)$ & $(0.010)$ & $(0.014)$ & $(0.016)$ \\
\hline \multirow{2}{*}{$\begin{array}{l}\text { Post-secondary, non- } \\
\text { tertiary }\end{array}$} & -0.036 & $-0.071^{* *}$ & $-0.051^{*}$ & $-0.061^{* * *}$ & $-0.072^{* * *}$ & -0.050 & $-0.053^{* * *}$ & -0.023 & 0.000 & -0.0 & -0.009 \\
\hline & $(0.026)$ & $(0.030)$ & $(0.027)$ & $(0.014)$ & $(0.026)$ & $(0.035)$ & $(0.019)$ & $(0.026)$ & $(0.000)$ & $(0.041)$ & $(0.020)$ \\
\hline \multirow[t]{2}{*}{ Tertiary } & $-0.058^{\text {zat* }}$ & $-0.081^{\text {zz* }}$ & $-0.095^{\text {tatk}}$ & $-0.067^{* 2 *}$ & $-0.052^{* *}$ & $-0.064^{\text {tat: }}$ & $-0.094^{\text {tatk}}$ & $-0.036^{*}$ & $-0.114^{\text {z***}}$ & -0.014 & -0.021 \\
\hline & $(0.012)$ & $(0.021)$ & $(0.014)$ & $(0.011)$ & $(0.021)$ & $(0.012)$ & $(0.012)$ & $(0.018)$ & $(0.016)$ & $(0.016)$ & $(0.017)$ \\
\hline \multirow[t]{2}{*}{ Firm size: $11-50$} & -0.006 & -0.011 & 0.013 & -0.008 & 0.005 & -0.007 & 0.004 & -0.013 & 0.002 & -0.010 & -0.007 \\
\hline & $(0.010)$ & $(0.011)$ & $(0.013)$ & $(0.009)$ & $(0.011)$ & $(0.011)$ & $(0.011)$ & $(0.014)$ & $(0.011)$ & $(0.013)$ & $(0.017)$ \\
\hline \multirow[t]{2}{*}{ Firm size: $51-250$} & -0.013 & 0.008 & -0.016 & -0.012 & 0.001 & $-0.032^{* z}$ & 0.008 & 0.010 & $-0.040^{* * x}$ & 0.004 & -0.002 \\
\hline & $(0.012)$ & $(0.010)$ & $(0.017)$ & $(0.010)$ & $(0.009)$ & $(0.013)$ & $(0.014)$ & $(0.014)$ & $(0.013)$ & $(0.014)$ & $(0.016)$ \\
\hline \multirow[t]{2}{*}{ Firm size: $251-999$} & -0.027 & -0.005 & -0.017 & $-0.021^{*}$ & 0.000 & $-0.034^{\mathrm{kt}}$ & -0.009 & $-0.035^{*}$ & $-0.034^{\text {** }}$ & -0.020 & -0.034 \\
\hline & $(0.019)$ & $(0.015)$ & $(0.017)$ & $(0.012)$ & $(0.023)$ & $(0.017)$ & $(0.020)$ & $(0.021)$ & $(0.016)$ & $(0.018)$ & $(0.025)$ \\
\hline \multirow[t]{2}{*}{ Firm size: $>1000$} & -0.033 & -0.027 & -0.041 & -0.023 & $-0.054^{* \pm}$ & $-0.054^{\text {*t*k }}$ & 0.010 & -0.032 & -0.019 & 0.008 & -0.035 \\
\hline & $(0.020)$ & $(0.028)$ & $(0.027)$ & $(0.015)$ & $(0.026)$ & $(0.020)$ & $(0.030)$ & $(0.026)$ & $(0.021)$ & $(0.018)$ & $(0.028)$ \\
\hline \multirow[t]{2}{*}{ Fixed contract } & 0.010 & -0.009 & $-0.046^{*}$ & -0.005 & $-0.020^{*}$ & -0.000 & 0.001 & -0.021 & -0.015 & 0.015 & 0.014 \\
\hline & $(0.016)$ & $(0.015)$ & $(0.025)$ & $(0.011)$ & $(0.012)$ & $(0.013)$ & $(0.013)$ & $(0.018)$ & $(0.016)$ & $(0.015)$ & $(0.015)$ \\
\hline \multirow{2}{*}{$\begin{array}{l}\text { Temp agency/No } \\
\text { contract/Apprenticeship }\end{array}$} & 0.013 & 0.004 & -0.020 & -0.002 & -0.006 & 0.002 & 0.032 & 0.011 & 0.010 & 0.001 & $-0.033^{*}$ \\
\hline & $(0.013)$ & $(0.015)$ & $(0.028)$ & $(0.008)$ & $(0.021)$ & $(0.018)$ & $(0.020)$ & $(0.031)$ & $(0.019)$ & $(0.019)$ & $(0.019)$ \\
\hline \multirow[t]{2}{*}{ Part-time worker } & -0.006 & -0.005 & -0.003 & -0.015 & 0.013 & -0.016 & 0.002 & -0.007 & 0.002 & -0.001 & -0.002 \\
\hline & $(0.014)$ & $(0.011)$ & $(0.014)$ & $(0.012)$ & $(0.014)$ & $(0.012)$ & $(0.015)$ & $(0.019)$ & $(0.011)$ & $(0.010)$ & $(0.016)$ \\
\hline \multirow[t]{2}{*}{ Public sector/NGO } & -0.021 & 0.005 & $0.024^{* *}$ & 0.010 & -0.001 & $0.039^{* * 2}$ & $0.015^{*}$ & 0.014 & $0.034^{* 2 *}$ & $0.020^{* *}$ & -0.008 \\
\hline & $(0.014)$ & $(0.009)$ & $(0.011)$ & $(0.008)$ & $(0.010)$ & $(0.009)$ & $(0.008)$ & $(0.012)$ & $(0.011)$ & $(0.009)$ & $(0.013)$ \\
\hline Number of observations & 3262 & 2539 & 2464 & 13145 & 2179 & 3722 & 3648 & 2498 & 3025 & 2728 & 2316 \\
\hline
\end{tabular}


ECO/WKP(2015)28

\begin{tabular}{|c|c|c|c|c|c|c|c|c|c|c|c|}
\hline & (12) & (13) & (14) & (15) & (16) & (17) & (18) & (19) & (20) & (21) & $(22)$ \\
\hline & Italy & Japan & Korea & Netherlands & Norway & Poland & $\begin{array}{c}\text { Slovak } \\
\text { Republic }\end{array}$ & Spain & teden & $\begin{array}{c}\text { United } \\
\text { Kingdom }\end{array}$ & $\begin{array}{l}\text { United } \\
\text { States }\end{array}$ \\
\hline \multicolumn{12}{|c|}{ Dependent variable: 1 if the individual is under-skilled, 0 otherwise } \\
\hline \multirow[t]{2}{*}{ Single } & -0.016 & -0.010 & 0.000 & 0.007 & -0.017 & 0.000 & 0.0 & -0.014 & 0.024 & $.037^{ \pm *}$ & 0.012 \\
\hline & $(0.026)$ & $(0.013)$ & $(0.011)$ & $(0.017)$ & $(0.017)$ & $(0.010)$ & $(0.016)$ & $(0.013)$ & $(0.018)$ & $(0.018)$ & $(0.013)$ \\
\hline \multirow[t]{2}{*}{ Female } & 0.007 & 0.004 & $0.015^{*}$ & & -0.019 & 0.005 & -0.005 & $0.020^{*}$ & -0.012 & -0.010 & -0.007 \\
\hline & $(0.022)$ & $(0.010)$ & $(0.009)$ & $(0.011)$ & $(0.012)$ & $(0.010)$ & $(0.013)$ & $(0.011)$ & $(0.014)$ & $(0.015)$ & $(0.008)$ \\
\hline \multirow[t]{2}{*}{ Immigrant } & $0.150^{* \pm *}$ & $0.100^{\text {*z* }}$ & 0.047 & $0.099^{* * *}$ & $0.106^{* * *}$ & 0.000 & $-0.139^{* *}$ & $0.052^{* * *}$ & $0.126^{* * *}$ & $0.095^{ \pm * *}$ & $0.063^{* * t}$ \\
\hline & $(0.034)$ & $(0.033)$ & $(0.0$ & $(0.0$ & $(0.014)$ & $(0.000)$ & $(0.054)$ & $(0.013)$ & $(0.0$ & $(0.018)$ & $(0.012)$ \\
\hline \multirow[t]{2}{*}{ Age $25-34$} & -0.078 & 0.00 & 0.08 & 0.0 & 0.0 & $0.025^{*}$ & 0.002 & -0.015 & 0.0 & 0.0 & -0.015 \\
\hline & $(0.054)$ & $(0.025)$ & $(0.05$ & $(0.0$ & $(0.026)$ & $(0.0$ & $(0.027)$ & $(0.0$ & $(0.0$ & $(0.0$ & $(0.023)$ \\
\hline \multirow[t]{2}{*}{ Age $35-44$} & -0.053 & -0.000 & 0.07 & 0.0 & -0.014 & 0.0 & 0.0 & -0.007 & 0.0 & 0.0 & -0.019 \\
\hline & $(0.053)$ & $(0.024)$ & $(0.0$ & $(0.0$ & $(0.0$ & $(0.019)$ & $(0.0)$ & $(0.0$ & $(0.0$ & & $(0.020)$ \\
\hline \multirow[t]{2}{*}{ Age $45-54$} & -0.071 & 0.03 & 0.10 & 0.08 & 0.05 & 0.04 & & & 0.10 & 0.052 & 0.021 \\
\hline & $(0.056)$ & $(0.024)$ & $(0.0$ & $(0.0$ & $(0.025)$ & $(0.016)$ & $(0.0$ & $(0.0$ & $(0 . C$ & $(0.034)$ & $(0.022)$ \\
\hline \multirow[t]{2}{*}{ Age 55-65 } & 0.00 & 0.087 & 0.12 & 0.10 & 0.09 & & 0.0 & 0.06 & 0.15 & $0.070^{* \pm}$ & 0.028 \\
\hline & $(0.0$ & $(0.02$ & $(0.0$ & $(0.0$ & $(0.0$ & $(0.0$ & $(0 . c)$ & $(0 . c$ & & & $(0$. \\
\hline \multirow[t]{2}{*}{ Upper secondary } & -0.05 & -0.0 & -0.02 & -0.0 & -0.0 & -0.0 & -0 . & -0.0 & -0.0 & $-0.065^{* * *}$ & $-0.044^{* * * t}$ \\
\hline & $(0.0$ & $(0.0$ & $(0.0$ & $(0.0$ & 00 & $(0.0$ & $(0.0$ & & & & \\
\hline \multirow{2}{*}{$\begin{array}{l}\text { Post-secondary, non- } \\
\text { tertiary }\end{array}$} & -0.076 & -0.043 & 0.00 & 0. & -0.037 & $-0.066^{* * x}$ & -0.034 & 0.018 & $-0.0 s$ & 0.000 & $-0.046^{* *}$ \\
\hline & $(0.101)$ & $(0.039)$ & $(0.000)$ & $(0.000)$ & $(0.022)$ & $(0.025)$ & $(0.053)$ & $(0.029)$ & $(0.028)$ & $(0.000)$ & $(0.019)$ \\
\hline \multirow{2}{*}{ Tertiary } & -0.034 & $-0.071^{* * *}$ & $-0.068^{* \pm *}$ & $-0.064^{* * *}$ & $-0.036^{* *}$ & $-0.066^{* * *}$ & 0.023 & $-0.050^{* * *}$ & $-0.096^{* * *}$ & $-0.059^{* * *}$ & $-0.077^{* * x}$ \\
\hline & $(0.030)$ & $(0.014)$ & $(0.016)$ & $(0.015)$ & $(0.015)$ & $(0.0$ & & $(0.013)$ & & & $(0.019)$ \\
\hline \multirow[t]{2}{*}{ Firm size: $11-50$} & $-0.065^{\text {t* }}$ & $0.022^{*}$ & -0.0 & -0.03 & 0.0 & 0.0 & -0.0 & & & & \\
\hline & $(0.03$ & $(0.01$ & $(0.0$ & $(0.0$ & $(0.0$ & $(0.0$ & $(0.0$ & & & $(0$. & \\
\hline \multirow[t]{2}{*}{ Firm size: $51-250$} & -0.033 & 0.00 & 0.0 & -0.06 & 0.0 & -0.009 & $-0.045^{* *}$ & 0.0 & -0.0 & -0.016 & 0.005 \\
\hline & $(0.032)$ & $(0.0$ & & & & $(0.0$ & $(0.020)$ & & & $(0.026)$ & \\
\hline \multirow[t]{2}{*}{ Firm size: $251-999$} & $-0.159^{* * z}$ & $0.031^{*}$ & -0.009 & $-0.053^{\text {**z }}$ & 0.024 & 0.011 & $-0.069^{* * z}$ & -0.001 & -0.027 & -0.014 & 0.013 \\
\hline & $(0.059)$ & $(0.018)$ & $(0.017)$ & $(0.019)$ & $(0.021)$ & $(0.017)$ & $(0.026)$ & $(0.025)$ & $(0.025)$ & $(0.023)$ & $(0.022)$ \\
\hline \multirow[t]{2}{*}{ Firm size: $>1000$} & -0.008 & 0.004 & -0.028 & -0.026 & -0.014 & -0.004 & $-0.089^{* *}$ & 0.022 & -0.005 & 0.011 & 0.014 \\
\hline & $(0.042)$ & $(0.024)$ & $(0.023)$ & $(0.019)$ & $(0.025)$ & $(0.020)$ & & $(0.02)$ & & & $(0.030)$ \\
\hline \multirow[t]{2}{*}{ Fixed contract } & 0.003 & -0.006 & -0.004 & -0.009 & 0.020 & -0.003 & 0.025 & -0.008 & 0.020 & 0.000 & -0.022 \\
\hline & & & & & & & & & & & \\
\hline \multirow{2}{*}{$\begin{array}{l}\text { Temp agency/No } \\
\text { contract/Apprenticeship }\end{array}$} & -0.070 & -0.010 & 0.003 & $-0.042^{*}$ & 0.018 & 0.025 & -0.017 & -0.010 & -0.007 & 0.012 & -0.008 \\
\hline & & $(0.02$ & & & & & & & & & \\
\hline \multirow[t]{2}{*}{ Part-time worker } & $0.054^{* *}$ & -0.007 & -0.002 & -0.006 & $0.058^{ \pm * 2 *}$ & -0.015 & 0.040 & $-0.032^{*}$ & -0.006 & -0.019 & -0.023 \\
\hline & $(0.021)$ & $(0.011)$ & $(0.014)$ & $(0.013)$ & $(0.015)$ & $(0.018)$ & $(0.028)$ & $(0.019)$ & $(0.021)$ & $(0.017)$ & $(0.025)$ \\
\hline \multirow[t]{2}{*}{ Public sector/NGO } & $0.049^{*}$ & -0.016 & 0.003 & 0.005 & $0.031^{ \pm * *}$ & -0.008 & $0.052^{\star \star * *}$ & 0.010 & 0.011 & 0.003 & -0.002 \\
\hline & $(0.027)$ & $(0.014)$ & $(0.013)$ & $(0.011)$ & $(0.012)$ & $(0.013)$ & $(0.013)$ & $(0.014)$ & $(0.016)$ & $(0.017)$ & $(0.012)$ \\
\hline umber of observations & 1666 & 2942 & 2568 & 2712 & 2417 & 3282 & 2478 & 2246 & 2107 & 3772 & 2062 \\
\hline
\end{tabular}

Notes: Estimates from logit regressions. Values are marginal effects. The coefficients correspond to the impact of a change in the explanatory variable on the probability of mismatch at the mean of the independent variables. Regressions include as controls age, marital and migrant status, gender, level of education, firm size, contract type, a dummy for working full-time and working in the private sector. Robust standard errors in parentheses. ${ }^{* * *}$ denotes statistical significance at the $1 \%$ level, ${ }^{* *}$ significance at the $5 \%$ level, ${ }^{*}$ significance at the $10 \%$ level.

Source: OECD calculations based on the Survey of Adult Skills (2012). 
ECO/WKP(2015)28

\section{APPENDIX C. MISMATCH AND POLICIES}

\section{Table C1. The effect of policy-related factors on over-skilling}

\begin{tabular}{|c|c|c|c|c|c|}
\hline & (1) & $(2)$ & (3) & $(4)$ & $(5)$ \\
\hline \multicolumn{6}{|c|}{ Dependent variable: 1 if the individual is over-skilled, 0 otherwise } \\
\hline Panel A: Framework policies & $\begin{array}{l}\text { Product market } \\
\text { regulation }\end{array}$ & $\begin{array}{l}\text { Employment } \\
\text { protection } \\
\text { legislation for } \\
\text { permanent } \\
\text { workers }\end{array}$ & $\begin{array}{c}\text { Employment } \\
\text { protection } \\
\text { legislation for } \\
\text { temporary } \\
\text { workers }\end{array}$ & $\begin{array}{c}\text { Cost of closing a } \\
\text { business }\end{array}$ & \\
\hline \multirow{2}{*}{ Policy-related factors } & $0.029^{* 2}$ & $0.038^{* \pm *}$ & $0.048^{* *}$ & $0.004^{\text {*** }}$ & \\
\hline & $(0.013)$ & $(0.007)$ & $(0.020)$ & $(0.000)$ & \\
\hline Number of observations & 64348 & 64348 & 64348 & 64348 & \\
\hline Panel B: Housing policies & $\begin{array}{c}\text { Transaction } \\
\text { costs }\end{array}$ & Rent control & $\begin{array}{c}\text { Tenant-landlord } \\
\text { regulations }\end{array}$ & $\begin{array}{l}\text { Cost of obtaining } \\
\text { a building permit }\end{array}$ & $\begin{array}{c}\text { Responsiveness of } \\
\text { housing supply }\end{array}$ \\
\hline \multirow{2}{*}{ Policy-related factors } & $0.006^{* \pm *}$ & $0.021^{\text {t*k }}$ & $0.017^{* * *}$ & 0.000 & $-0.038^{* * 2}$ \\
\hline & $(0.001)$ & $(0.003)$ & $(0.003)$ & $(0.000)$ & $(0.009)$ \\
\hline Number of observations & 64348 & 58344 & 60811 & 64348 & 54370 \\
\hline Panel C: Other policies & $\begin{array}{c}\text { Coverage rate of } \\
\text { collective } \\
\text { bargaining } \\
\text { agreements }\end{array}$ & $\begin{array}{l}\text { Participation in } \\
\text { lifelong learning } \\
\text { (PIAAC data) }\end{array}$ & $\begin{array}{l}\text { Participation in } \\
\text { lifelong learning } \\
\text { (EU data) }\end{array}$ & $\begin{array}{c}\text { Managerial } \\
\text { quality }\end{array}$ & \\
\hline Policy-related factors & $\begin{array}{l}0.001^{\text {t*z }} \\
(0.000)\end{array}$ & $\begin{array}{l}-0.001^{ \pm *} \\
(0.000)\end{array}$ & $\begin{array}{l}-0.001^{\text {tat: }} \\
(0.000)\end{array}$ & $\begin{array}{l}-0.001^{* x *} \\
(0.000)\end{array}$ & \\
\hline Number of observations & 64348 & 64348 & 44274 & 63340 & \\
\hline
\end{tabular}

Notes: Estimates from logit regressions. Values are marginal effects. The coefficients correspond to the impact of a change in the explanatory variable on the probability of mismatch at the mean of the independent variables. Regressions include as controls age, marital and migrant status, gender, level of education, firm size, contract type, a dummy for working full-time and working in the private sector. Robust standard errors in parentheses. ${ }^{* * *}$ denotes statistical significance at the $1 \%$ level, ${ }^{* *}$ significance at the $5 \%$ level, ${ }^{*}$ significance at the $10 \%$ level.

Source: OECD calculations based on the Survey of Adult Skills (2012). 
Table C2. The effect of policy-related factors on under-skilling

\begin{tabular}{|c|c|c|c|c|c|}
\hline & (1) & $(2)$ & (3) & $(4)$ & $(5)$ \\
\hline \multicolumn{6}{|c|}{ Dependent variable: 1 if the individual is under-skilled, 0 otherwise } \\
\hline Panel A: Framework policies & $\begin{array}{l}\text { Product market } \\
\text { regulation }\end{array}$ & $\begin{array}{l}\text { Employment } \\
\text { protection } \\
\text { legislation for } \\
\text { permanent } \\
\text { workers }\end{array}$ & $\begin{array}{l}\text { Employment } \\
\text { protection } \\
\text { legislation for } \\
\text { temporary } \\
\text { workers }\end{array}$ & $\begin{array}{c}\text { Cost of closing a } \\
\text { business }\end{array}$ & \\
\hline Policy-related factors & $\begin{array}{c}0.001 \\
(0.007)\end{array}$ & $\begin{array}{l}0.007^{*} \\
(0.004)\end{array}$ & $\begin{array}{l}0.004^{\text {*t }} \\
(0.002)\end{array}$ & $\begin{array}{l}0.002^{\text {**** }} \\
(0.000)\end{array}$ & \\
\hline Number of observations & 64348 & 64348 & 64348 & 64348 & \\
\hline Panel B: Housing policies & $\begin{array}{l}\text { Transaction } \\
\text { costs }\end{array}$ & Rent control & $\begin{array}{l}\text { Tenant-landlord } \\
\text { regulations }\end{array}$ & $\begin{array}{l}\text { Cost of obtaining } \\
\text { a building permit }\end{array}$ & $\begin{array}{c}\text { Responsiveness of } \\
\text { housing supply }\end{array}$ \\
\hline Policy-related factors & $\begin{array}{c}0.000 \\
(0.000)\end{array}$ & $\begin{array}{l}-0.021 \\
(0.002)\end{array}$ & $\begin{array}{l}0.003^{*} \\
(0.002)\end{array}$ & $\begin{array}{l}0.000^{* * *} \\
(0.000)\end{array}$ & $\begin{array}{c}-0.015^{* * *} \\
(0.005)\end{array}$ \\
\hline Number of observations & 64348 & 58344 & 60811 & 64348 & 54370 \\
\hline Panel C: Other policies & $\begin{array}{l}\text { Coverage rate of } \\
\text { collective } \\
\text { bargaining } \\
\text { agreements }\end{array}$ & $\begin{array}{l}\text { Participation in } \\
\text { lifelong learning } \\
\text { (PIAAC data) }\end{array}$ & $\begin{array}{l}\text { Participation in } \\
\text { lifelong learning } \\
\text { (EU data) }\end{array}$ & Managerial quality & \\
\hline Policy-related factors & $\begin{array}{l}0.000^{* *} \\
(0.000)\end{array}$ & $\begin{array}{c}-0.001^{* \pm *} \\
(0.000)\end{array}$ & $\begin{array}{l}-0.000 \\
(0.000)\end{array}$ & $\begin{array}{c}-0.001^{ \pm *:} \\
(0.000)\end{array}$ & \\
\hline Number of observations & 64348 & 64348 & 44274 & 63340 & \\
\hline
\end{tabular}

Notes: Estimates from logit regressions. Values are marginal effects. The coefficients correspond to the impact of a change in the explanatory variable on the probability of mismatch at the mean of the independent variables. Regressions include as controls age, marital and migrant status, gender, level of education, firm size, contract type, a dummy for working full-time and working in the private sector. Robust standard errors in parentheses. ${ }^{* * *}$ denotes statistical significance at the $1 \%$ level, ${ }^{* *}$ significance at the $5 \%$ level, ${ }^{*}$ significance at the $10 \%$ level.

Source: OECD calculations based on the Survey of Adult Skills (2012). 
Figure C1. The impact of policies on skill mismatch

Reduction in mismatch associated with policy reform to best practice level

A. Stringency of Product Market Regulations

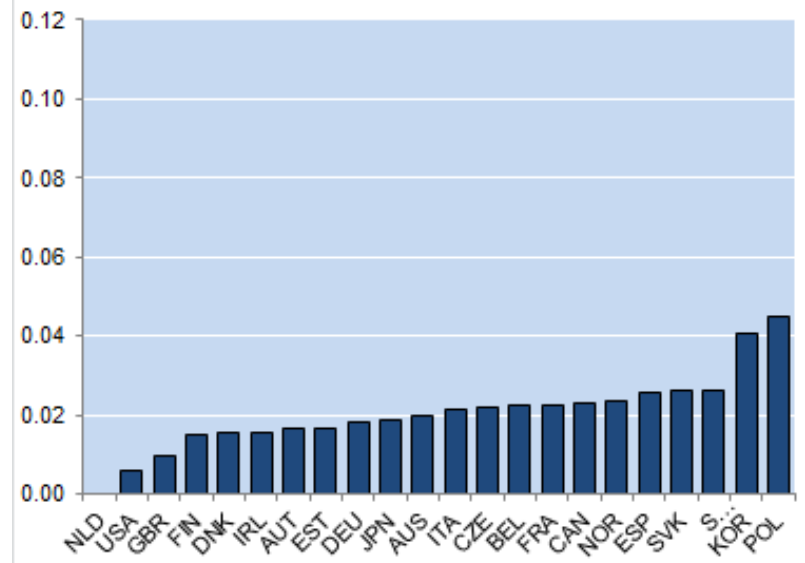

C: Cost of Bankruptcy Legislation

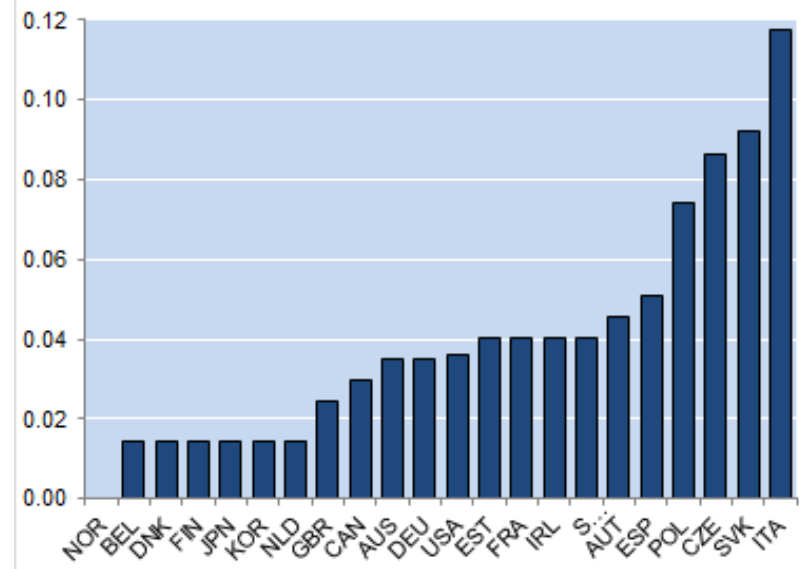

B. Stringency of Employment Protection Legislation

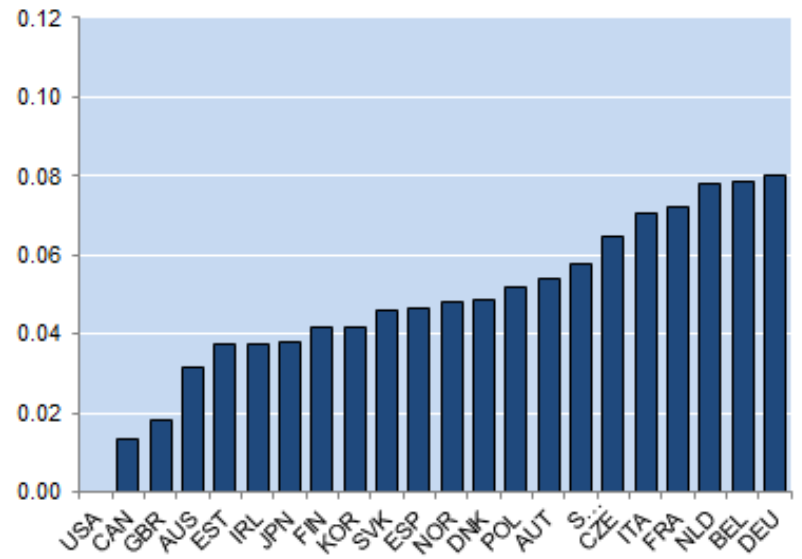

D: Transaction Costs on Buying Dwellings

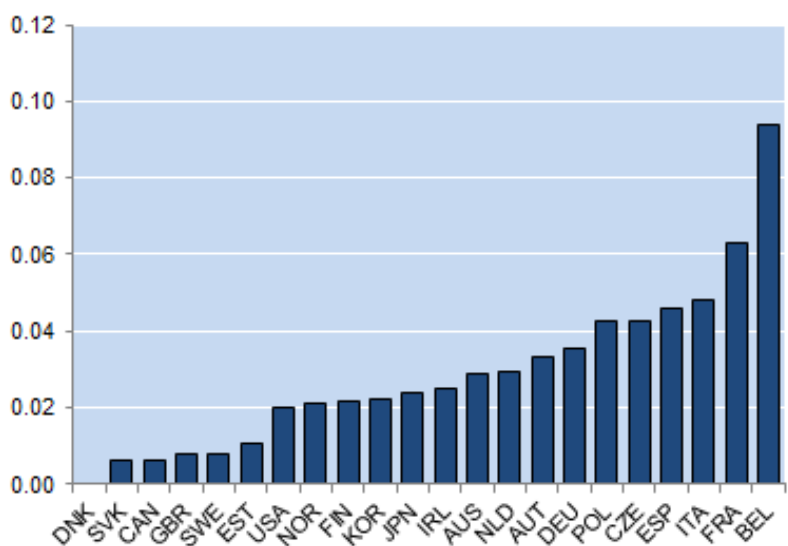

Notes: Estimation of cross-country reductions in skill mismatch from reforms to the best practice level of four policy variables. Product Market Regulation is the aggregate indicator for 2008. Employment Protection Legislation refers to that of permanent workers against individual and collective dismissals for 2013. The cost of bankruptcy legislation, proxied by cost of closing a business, is calculated on the basis of questionnaire responses and includes court fees and government levies; fees of insolvency administrators, auctioneers, assessors and lawyers; and all other fees and costs. Transaction costs include a number of fees such as transfer taxes (e.g. stamp duties), registration fees incurred when registering the property in the land registry, notarial or other legal fees and typical real estate agency fees and refer to 2009.

Source: OECD calculations based on the Survey of Adult Skills (2012). 


\section{APPENDIX D. ADDITIONAL ROBUSTNESS CHECKS}

Table D1. Correlations between selected policy-related variables

A: Framework policies

\begin{tabular}{lcccc}
\hline & $\begin{array}{c}\text { Product } \\
\text { market } \\
\text { regulation }\end{array}$ & $\begin{array}{c}\text { EPL } \\
\text { (permanent) }\end{array}$ & $\begin{array}{c}\text { EPL } \\
\text { (temporary) }\end{array}$ & $\begin{array}{c}\text { Cost of } \\
\text { closing a } \\
\text { business }\end{array}$ \\
\cline { 2 - 5 } Product market regulation & 1.00 & & & \\
\hline EPL (permanent) & 0.17 & 1.00 & & \\
EPL (temporary) & 0.42 & 0.63 & 1.00 & 1.00 \\
\hline $\begin{array}{l}\text { Cost of closing a } \\
\text { business }\end{array}$ & 0.29 & 0.21 & 0.23 & 1.00 \\
\hline
\end{tabular}

B: Other policies

\begin{tabular}{|c|c|c|c|c|c|c|c|}
\hline & $\begin{array}{c}\text { Transaction } \\
\text { Costs }\end{array}$ & Rent control & $\begin{array}{l}\text { Tenant- } \\
\text { landlord } \\
\text { regulations }\end{array}$ & $\begin{array}{l}\text { Cost of } \\
\text { obtaining a } \\
\text { building } \\
\text { permits }\end{array}$ & $\begin{array}{c}\text { Responsive } \\
\text { ness of } \\
\text { housing } \\
\text { supply }\end{array}$ & $\begin{array}{c}\text { Coverage rate } \\
\text { of collective } \\
\text { bargaining } \\
\text { agreements }\end{array}$ & $\begin{array}{c}\text { Participation } \\
\text { in lifelong } \\
\text { learning }\end{array}$ \\
\hline Transaction Costs & 1.00 & & & & & & \\
\hline Rent control & 0.01 & 1.00 & & & & & \\
\hline $\begin{array}{l}\text { Tenant-landlord } \\
\text { requlations }\end{array}$ & 0.46 & 0.61 & 1.00 & & & & \\
\hline $\begin{array}{l}\text { Cost of obtaining a } \\
\text { buildinq permits }\end{array}$ & 0.26 & -0.06 & -0.16 & 1.00 & & & \\
\hline $\begin{array}{l}\text { Responsiveness of } \\
\text { housina supply }\end{array}$ & -0.53 & -0.05 & -0.30 & -0.26 & 1.00 & & \\
\hline $\begin{array}{l}\text { Coverage rate of } \\
\text { collective barqaining }\end{array}$ & 0.35 & 0.56 & 0.77 & -0.15 & -0.40 & 1.00 & \\
\hline $\begin{array}{l}\text { Participation in lifelong } \\
\text { learning }\end{array}$ & -0.60 & 0.27 & -0.06 & -0.43 & 0.46 & 0.09 & 1.00 \\
\hline
\end{tabular}

C: Framework and other policies

\begin{tabular}{lcccc}
\hline & $\begin{array}{c}\text { Product } \\
\text { market } \\
\text { regulation }\end{array}$ & $\begin{array}{c}\text { EPL } \\
\text { (permanent) }\end{array}$ & $\begin{array}{c}\text { EPL } \\
\text { (temporary) }\end{array}$ & $\begin{array}{c}\text { Cost of } \\
\text { closing a } \\
\text { business }\end{array}$ \\
\cline { 2 - 5 } Transaction Costs & 0.20 & 0.64 & 0.51 & 0.19 \\
$\begin{array}{l}\text { Rent control } \\
\begin{array}{l}\text { Tenant-landlord } \\
\text { requlations }\end{array}\end{array}$ & -0.08 & 0.62 & 0.15 & 0.07 \\
$\begin{array}{l}\text { Cost of obtaining a } \\
\text { buildinq permits }\end{array}$ & 0.05 & 0.83 & 0.57 & 0.04 \\
$\begin{array}{l}\text { Responsiveness of } \\
\text { housinq supply }\end{array}$ & -0.08 & -0.59 & -0.51 & -0.19 \\
$\begin{array}{l}\text { Participation in lifelong } \\
\text { learninq } \\
\begin{array}{l}\text { Coverage rate of } \\
\text { collective barqaining }\end{array}\end{array}$ & -0.44 & -0.30 & -0.44 & -0.73 \\
\hline
\end{tabular}

Notes: See Section 4.2 and Table A1 for details on the policy variables. 
ECO/WKP(2015)28

Table D2. Including several policies together: robustness checks

\begin{tabular}{|c|c|c|c|c|c|c|c|}
\hline & (1) & (2) & (3) & (4) & (5) & (6) & (7) \\
\hline \multicolumn{8}{|c|}{ Dependent variable: 1 if the individual is mismatched, 0 otherwise } \\
\hline Product market regulation & $\begin{array}{c}0.030 \\
(0.015)^{ \pm *}\end{array}$ & & & & & & \\
\hline EPL (permanent) & & $\begin{array}{l}0.037 \\
(0.008)^{ \pm \pm 2}\end{array}$ & & & & & \\
\hline EPL (temporary) & & & $\begin{array}{c}0.007 \\
(0.003)^{* *}\end{array}$ & $\begin{array}{l}0.012 \\
(0.003)^{ \pm * *}\end{array}$ & & & \\
\hline Cost of closing a business & & & & $\begin{array}{c}0.004 \\
(0.001)^{ \pm \pm *}\end{array}$ & $\begin{array}{c}0.004 \\
(0.001)^{ \pm * *}\end{array}$ & & \\
\hline Rent control & $\begin{array}{l}0.004 \\
0.004\end{array}$ & & $\begin{array}{c}0.016 \\
(0.004)^{* *}\end{array}$ & $\begin{array}{c}0.011 \\
(0.003)^{* \pm *}\end{array}$ & & $\begin{array}{c}0.005 \\
(0.004)\end{array}$ & $\begin{array}{c}0.010 \\
(0.003)^{* * *}\end{array}$ \\
\hline $\begin{array}{l}\text { Cost of obtaining a building } \\
\text { permits }\end{array}$ & & $\begin{array}{c}0.000 \\
(0.000)\end{array}$ & & & & & $\begin{array}{c}0.001 \\
(0.000)^{* *}\end{array}$ \\
\hline Transaction Costs & & & & & $\begin{array}{c}0.003 \\
(0.001)^{* \pm *}\end{array}$ & $\begin{array}{c}0.002 \\
(0.001)^{ \pm}\end{array}$ & $\begin{array}{c}0.004 \\
(0.001)^{* \pm *}\end{array}$ \\
\hline $\begin{array}{l}\text { Coverage rate of collective } \\
\text { bargaining agreements }\end{array}$ & $\begin{array}{c}0.001 \\
(0.000)^{* \pm *}\end{array}$ & & & & & $\begin{array}{c}0.001 \\
(0.000)^{* * *}\end{array}$ & \\
\hline $\begin{array}{l}\text { Participation in lifelong } \\
\text { learning }\end{array}$ & & $\begin{array}{c}-0.001 \\
(0.000)^{* \pm *}\end{array}$ & $\begin{array}{c}-0.002 \\
(0.000)^{* \pm *}\end{array}$ & & & & \\
\hline Number of observations & 58344 & 64348 & 58344 & 58344 & 64348 & 58344 & 58344 \\
\hline pseudo-R2 & 0.013 & 0.014 & 0.014 & 0.015 & 0.012 & 0.012 & 0.013 \\
\hline
\end{tabular}

Notes: Estimates from logit regressions, including several policy variables together. Values are marginal effects. The coefficients correspond to the impact of a change in the explanatory variable on the probability of mismatch at the mean of the independent variables. Regressions include as controls age, marital and migrant status, gender, level of education, firm size, contract type, a dummy for working full-time and working in the private sector. Robust standard errors in parentheses. ${ }^{* *}$ denotes statistical significance at the $1 \%$ level, ${ }^{* *}$ significance at the $5 \%$ level, ${ }^{*}$ significance at the $10 \%$ level.

Source: OECD calculations based on the Survey of Adult Skills (2012). 


\section{WORKING PAPERS}

The full series of Economics Department Working Papers can be consulted at www.oecd.org/eco/workingpapers

1209. Labour market mismatch and labour productivity: evidence from PIAAC data

(April 2015) by Müge Adalet McGowan and Dan Andrews

1208. Maintaining an efficient and equitable housing market in Belgium

(April 2015) by Sanne Zwart

1207. Determinants of the low female labour force participation in India

(April 2015) by Piritta Sorsa, Jan Mares, Mathilde Didier, Caio Guimaraes, Marie Rabate,

Gen Tang and Annamaria Tuske

1206. Strengthening skill use and school-to-work transitions in the Czech Republic

(April 2015) by Sónia Araújo and Petr Malecek

1205. Reforming the tax on immovable property: taking care of the unloved:

(April 2015) by Hansjörg Blöchliger

1204. Taxation and investment in Colombia

(April 2015) by Sarah Perret and Bert Brys

1203. Efficiency and contestability in the Colombian banking system

(April 2015) by Christian Daude and Julien Pascal

1202. Fiscal decentralisation in Colombia: new evidence regarding sustainability, risk sharing and "fiscal fatigue"

(April 2015) by Guillaume Bousquet, Christian Daude and Christine de la Maisonneuve

1201. Effects of economic policies on microeconomic stability

(April 2015) by Boris Cournède, Paula Garda and Volker Ziemann

1200. The 2013 update of the OECD's database on product market regulation - policy insights for OECD and non-OECD countries

(April 2015) by Isabell Koske, Isabelle Wanner, Rosamaria Bitetti and Omar Barbiero

1199. Improving taxes and transfers in Australia

(April 2015) by Philip Hemmings and Annamaria Tuske

1198. Federal-state relations in Australia

(April 2015) by Vassiliki Koutsogeorgopoulou and Annamaria Tuske

1197. Sharing the fruits of growth with all Mexicans

(April 2015) by Eduardo Olaberriá and Valéry Dugain

1196. What makes Mexicans happy?

(April 2015) by Valéry Dugain and Eduardo Olaberriá

1195. Improving the labour market integration of immigrants in Belgium

(March 2015) by Álvaro Pina, Vincent Corluy and Gerlinde Verbist 
1194. Raising the potential of the domestically oriented sector in Germany

(March 2015) by André Eid and Andrés Hutfilter

1193. Improving transport infrastructure in Russia

(March 2015) by Alexander Kolik, Artur Radziwill and Natalia Turdyeva

1192. Improving the business climate in Russia

(March 2015) by Arthur Radziwill and Yana Vaziakova

1191. Determinants of female entrepreneurship in India

(March 2015) by Arnaud Daymard

1190. The changing role of the exchange rate for macroeconomic adjustment

(March 2015) by Patrice Ollivaud, Elena Rusticelli and Cyrille Schwellnus

1189. Boosting productivity in Russia: skills, education and innovation

(March 2015) by Lilas Demmou and Andreas Wörgötter

1188. Boosting growth and reducing informality in Mexico

(March 2015) by Sean Dougherty

1187. The conduct of monetary policy in the future: instrument use

(March 2015) by Kei-Ichiro Inaba, Rory O'Farrell, Łukasz Rawdanowicz and Ane Kathrine Christensen

1186. A constant market share analysis of Spanish goods

(February 2015) by Alberto Gonzalez Pandiella

1185. Raising the economic participation of women in India - a new growth engine?

(February 2015) by Piritta Sorsa

1184. Improving health outcomes and health care in India

(January 2015) by Isabelle Joumard and Ankit Kumar

1183. Challenges and opportunities of India's manufacturing sector

(January 2015) by Isabelle Joumard, Urban Sila and Hermes Morgavi

1182. The heterogeneity of product market regulations

(December 2014) by Jean-Marc Fournier

1181. Implicit regulatory barriers in the EU single market: new empirical evidence from gravity models

(December 2014) by Jean-Marc Fournier, Aurore Domps, Yaëlle Gorin, Xavier Guillet and Délia Morchoisne

1180. Can pro-growth policies lift all boats? An analysis based on household disposable income (December 2014) by Orsetta Causa, Alain de Serres and Nicolas Ruiz

1179. Empirical evidence on the effects of environmental policy stringency on productivity growth (December 2014) by Silvia Albrizio, Tomasz Koźluk and Vera Zipperer 